\title{
Policing for Profit: The Drug War's Hidden Economic Agenda
}

\author{
Eric Blumenson $\dagger$ \\ Eva Nilsen ††
}

\section{TABLE OF CONTENTS}

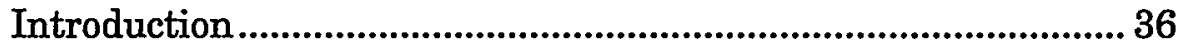

I. The Drug War Dividend.................................................. 42

A. Federal Aid to Drug Law Enforcement ........................ 42

B. Forfeiture and Asset Distribution ................................. 44

II. The Conflict of Interest Objections to Self-Financing

Police Agencies ................................................................. 56

A. The Due Process Objection ........................................ 57

B. Policy Objections ....................................................... 76

III. The Accountability Objections to Self-Financing

Police Agencies ......................................................................... 84

A. The Separation of Powers Objection.............................. 84

B. Policy Objections ............................................................ 93

IV. Remedies and Prospects.................................................. 100

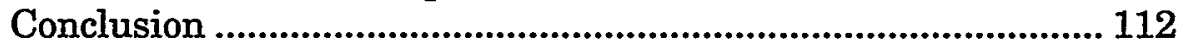

$\dagger$ Professor, Suffolk University Law School; J.D. 1972, Harvard Law School.

††Associate Clinical Professor of Law, Boston University Law School; J.D. 1977, University of Virginia Law School; LL.M. 1980, Georgetown University Law Center.

We presented an earlier version of this Article at the June 1997 meeting of the Law and Society Association and at faculty workshops at the Boston University School of Law and Suffolk University Law School. We are grateful to all participants and to the faculties at both institutions, who continued to provide thoughtful and valuable advice throughout the research and writing of the Article. We also thank Lawrence D. Weinberg for research assistance, and Dan Baum, Brenda Grantland, Eric Sterling, and Karen Tosh for leading us to much of the obscure but crucial data that appears herein. This research was supported by a grant from the Open Society Institute's Individual Project Fellowships Program. 
Asset seizures play an important role in the operation of [multijurisdictional drug] task forces. One "big bust" can provide a task force with the resources to become financially independent. Once financially independent, a task force can choose to operate without Federal or state assistance.

Report commissioned by the Department of Justice (Oct 1993)

[W] hat reason can there be, that a free people should be expos'd to all the insult and abuse, ... and even the fatal consequences, which may arise from the execution of a writ of assistance, only to put fortunes into private pockets.... [C]an a community be safe with an uncontroul'd power lodg'd in the hands of such officers ...?

James Otis, Boston Gazette (Jan 4, 1762)

\section{INTRODUCTION}

The Nixon Administration officially declared the "War on Drugs" twenty-five years ago. ${ }^{3}$ It has continued, at escalating levels, ever since. ${ }^{4}$ Today we annually spend $\$ 15$ billion in federal

1 Justice Research and Statistics Association ("JRSA"), Multijurisdictional Drug Control Task Forces: A Five-Year Review 1988-1992 9 (Oct 1993).

2 Attributed to James Otis, Article, Boston Gaz (Jan 4, 1762), reprinted in M.H. Smith, The Writs of Assistance Case 562, 565-66 (California 1978).

${ }^{3}$ In 1973, the Administration created the Drug Enforcement Administration ("DEA") to prosecute its "declared[,] all-out, global war on the drug menace." Message from the President of the United States Transmitting Reorganization Plan No. 2 of 1973, Establishing a Drug Enforcement Administration, HR Doc No 69, 93d Cong, 1st Sess 3 (Mar 28, 1973).

"President Reagan affirmed his administration's "unshakable" commitment "to do what is necessary to end the drug menace" by, among other things, increasing the number of federal drug task forces. Federal Initiatives Against Drug Trafficking and Organized Crime, 18 Weekly Comp Pres Doc 1311, 1313-14 (Oct 14, 1982). Later, President Bush appointed a drug "czar," William Bennett, who, among other things, sought the death penalty for drug sellers. Excerpts From News Session by Bush, Watkins and Bennett, NY Times D16 (Jan 13, 1989); Philip Shenon, Administration Offers a Tough New Drug Bill, NY Times A21 (May 17, 1990). The Bush Administration also contributed ever more militant rhetoric and increased federal budgets to the war effort. Its 1991, \$10.4 billion Drug War budget (of which 75 percent was earmarked for drug law enforcement) constituted a 62 percent increase over the 1989 budget, and a tenfold increase over the 1985 budget. John A. Powell and Eileen B. Hershenov, Hostage to the Drug War: The National Purse, The Constitution, and the Black Community, 24 UC Davis L Rev 557, 567 (1991). The Clinton Administration in turn has increased the antidrug budget by an additional 25 percent. Joshua Wolf Shenk, The Phony Drug War, The Nation 11, 12 (Sept 23, 1996). During Clinton's first term the number of marijuana-related arrests increased by 43 percent, and more Americans are in prison for such offenses than ever before. Eric Schlosser, More Reefer Madness, Atlantic Monthly 90 (Apr 1, 1997). The Clinton Administration also has proposed conditioning teenage drivers' licenses, parole, and welfare payments on manda- 
funds ${ }^{5}$ and $\$ 33$ billion in state and local funds to finance this war. ${ }^{6}$ Recent Federal Bureau of Investigation ("FBI") crime statistics report that in 1995 alone there were almost 1.5 million drug arrests, of which 500,000 were arrests for marijuana possession. ${ }^{7}$ Sixty percent of federal prisoners are incarcerated for drug offenses. $^{8}$

This massive outpouring of money and effort has produced record numbers of drug seizures, asset forfeitures, and prosecutions. ${ }^{9}$ By more meaningful measures, however, the Drug War has been an extraordinary failure. Drugs are more available-at higher purity and lower prices - than they were at the start of the decade. ${ }^{10}$ Drug dependence in the inner city ${ }^{11}$ and among teenag-

tory drug tests, see Joshua Wolf Shenk, Baring Teeth in the Drug War, NY Times A21 (Oct $30,1996)$, and promised federal intervention to nullify effectively the "medical marijuana" initiatives passed in California and Arizona. Doctors Given Federal Threat on Marijuana, NY Times A1 (Dec 31, 1996) (reporting Clinton Administration plans to revoke DEA registrations of physicians who recommend or prescribe "medical marijuana," including exclusion from participation in the Medicare and Medicaid programs).

5 The fiscal 1997 federal budget allocated $\$ 15.3$ billion to the drug war, $\$ 2$ billion more than the 1995 budget. Christopher S. Wren, Drugs Surge as a Campaign Issue, But All the Talk Clarifies Little, NY Times A1 (Sept 17, 1996). The comparable figures were $\$ 4.7$ billion in 1988, Shenk, NY Times at A21 (cited in note 4), and almost $\$ 1$ billion in 1980, T.R. Reid, A New Assault Planned Against Formidable Foe; Victories are Elusive in U.S. War On Drugs, Wash Post A1 (Aug 10, 1986).

B Barry R. McCaffrey, Director, Office of National Drug Control Policy, Fight Drugs as You Would a Disease, Chi Trib C18 (Mar 31, 1996).

7 The FBI estimates that in 1995 there were $1,476,100$ arrests for drug abuse violations, 41 percent more than in 1991 and 65 percent more than in 1986. Arrests for marijuana possession totaled 34.1 percent of these arrests, or over 503,000-more than the combined total number of arrests for murder, manslaughter, robbery, arson, vagrancy, rape, and all sex offenses including prostitution. Federal Bureau of Investigation, Uniform Crime Reports.for the United States 1995 207-08 (DOJ 1996).

${ }^{3}$ Marc Mauer and Tracy Huling, Young Black Americans and the Criminal Justice System: Five Years Later 11 (The Sentencing Project Oct 1995) (reporting that in 1993 drug offenders accounted for 60.8 percent of federal prisoners and 22.5 percent of state prisoners). Regarding the escalating imprisonment rates, see text accompanying notes 172-74.

- Federal drug prosecutions rose sharply from 1980 to 1992 before reaching a plateau. In 1981, when President Reagan took office, there were 8,775 federal drug prosecutions. The Bush and Clinton Administrations have each averaged just under 26,000 drug prosecutions a year, with the number rising to 28,585 in the election year 1992. Drug Prosecutions Up Significantly Since '81; Enforcement Boost by Reagan Continued Under Bush, Clinton, Chi Trib C6 (Oct 20, 1996) (reporting research by Transactional Records Access Clearinghouse at Syracuse University).

${ }^{10}$ In New York City in 1993, an average milligram of heroin was one-third of the 1979 price-and ten times the purity. Federal Law Enforcement Priorities, Hearings on $\mathbf{S} 3$ and S 38 Before the Senate Committee on the Judiciary, 104th Cong, 1st Sess 43, 50 (Feb 14, 1995) (statement of Thomas A. Constantine) (reporting a change from 1979 to 1993 from 6 percent purity to 66 percent purity, and from $\$ 1.60$ per milligram to $\$ .53$ per milligram). Meanwhile, newly popular synthetic drugs have emerged including fentanyl, MDMA or "ecstasy," and methcathinone or "CAT." Methamphetamine or "speed" has emerged as "the 


\section{$\mathrm{ers}^{12}$ has increased substantially. And the drug problem continues to produce massive amounts of crime, ${ }^{13} \$ 20$ billion in annual medical costs, ${ }^{14}$ one-third of all new HIV infections, ${ }^{15}$ prisons filled with drug-related offenders, ${ }^{16}$ and the attendant decimation of}

most significant dangerous drug problem in terms of domestic clandestine manufacture." Id at 48. See also Matt Bai, Colombian cartels pour pure heroin into Boston, Boston Globe A1 (Sept 4, 1996) (attributing an eighteenfold increase in heroin's purity per dollar over five years in part to the fact that the Colombian cartels have become exporters of heroin, not just cocaine).

According to a Senate Judiciary Committee report, between 1993 and the first half of 1995, "the ability of U.S. forces to seize or otherwise turn back drug shipments . . . dropped 53 percent. ... [Annually, as] much as 84 metric tons of additional cocaine and marijuana could be arriving unimpeded ... through the Eastern transit zone alone." This report, prepared by the Republican majority, attributes this to Clinton interdiction cutbacks, something the Administration denies. Majority Staff, Senate Committee on the Judiciary, Losing Ground Against Drugs: A Report on Increasing Illicit Drug Use and National Drug Policy (1995), in Trends in Youthful Drug Use, Hearing before the Senate Committee on the Judiciary, 104th Cong, 1st Sess 4, 13-14 (Dec 19, 1995).

${ }^{11}$ Although "fewer Americans are using drugs ... those who do have a much more serious problem, and helping them will prove far more difficult than anything that has so far been attempted." Michael Massing, What Ever Happened to the 'War on Drugs'?, NY Rev of Books 42, 42 (June 11, 1992) (arguing that the War on Drugs has attempted to safeguard suburbia while ignoring a progressively worsening inner-city drug problem). The one success has been a reduction in the total number of drug consumers by roughly half since the late seventies, to 12.8 million users. Department of Health and Human Services, National Household Survey on Drug Abuse: Main Findings 1995 (1997).

${ }^{12}$ Deptartment of Health and Human Services, National Household Survey on Drug Abuse. The survey showed that drug use among teenagers between twelve and seventeen years of age increased 105 percent between 1992 and 1995, to 10.9 percent of this population. Marijuana use increased 141 percent among teenagers during this period. The annual number of new users of marijuana has risen every year since 1991.

${ }^{13}$ The best estimate is that one-third of all property crimes, assaults, and murders are drug related. Hearing on McCaffrey Nomination Before the Senate Committee on the Judiciary, 104th Cong, 2d Sess 16 (Feb 27, 1996) (statement of General Barry R. McCaffrey, Director Designee of the Office of National Drug Control Policy). According to a survey reported by the DEA Administrator, four out of five males arrested in New York and Chicago tested positive for illegal drugs. Federal Law Enforcement Priorities Hearings at 47 (statement of Constantine) (cited in note 10). See also Kathleen Maguire and Ann L. Pastore, eds, Sourcebook of Criminal Justice Statistics 1993 427, 459-60 (DOJ 1994).

"Hearing on McCaffrey Nomination at 16 (statement of McCaffrey) (cited in note 13). General McCaffrey also estimates that from 1990 to 1995, "illegal drug abuse cost America more than $\$ 300$ billion and 100,000 dead." Id.

${ }^{15}$ Jeff Stryker and Mark D. Smith, eds, Dimensions of HIV Prevention: Needle Exchange vii (Kaiser Forums 1993) (reporting that approximately one-third of HIV infections derive from shared needles and syringes).

${ }^{16}$ The prison population has grown exponentially as ever-larger numbers of drug offenders are incarcerated. From 1983 to 1993, the number of prisoners incarcerated for drug crimes quintupled. Mauer and Huling, Young Black Americans at 10 (cited in note 8). For discussion of the increasing reliance on incarceration to solve our drug problem, see text accompanying notes $172-74$. 
inner-city communities. ${ }^{17}$ By all accounts, we have thus far been unable to spend and jail our way out of this problem.

Given these facts, and a general consensus that the Drug War has been a failure, ${ }^{18}$ one might wonder why essentially the same strategies persist year after year, untouched by the wisdom of twenty-five years of experience. And why do so few public and law enforcement officials speak out against this policy? The answer is that the Drug War has achieved a self-perpetuating life of its own, because however irrational it may be as public policy, it is fully rational as a political and bureaucratic strategy. Although the political impetus is well recognized-periodically demonstrated by the public demise of people deemed "soft on drugs," like former Surgeon General Jocelyn Elders, Judge Harold Baer, and ambassadorial nominee William Weld ${ }^{19}$-the bureaucratic

${ }^{17}$ In 1994, almost 7 percent of black adult males were incarcerated, compared to 1 percent of white adult males. Reuters, Nearly 7\% of Adult Black Men Were Inmates in '94, Study Says, NY Times A15 (Dec 4, 1995), citing a Department of Justice Report. The number of black males in their twenties under criminal justice supervision including incarceration, parole, or probation stood at 32.2 percent in 1995. Mauer and Huling, Young Black Americans at 1 (cited in note 8). One response, by high schools in Prince Georges County, Maryland, has been to invite police to teach classes on how to be arrested, handcuffed, and searched. Brett Pulley, Police Teach Getting Arrested Safely 101, Wall St J B1 (June 16, 1994).

Focusing on drug offenses, blacks comprise 12 percent of the population, 13 percent of all monthly drug users, 35 percent of those arrested for drug possession, 55 percent of those convicted of drug possession, and 74 percent of those sentenced to prison for drug possession. Mauer and Huling, Young Black Americans at 12 (cited in note 8) (compiling statistics from 1992 and 1993). Mauer and Huling also estimate that blacks and Hispanics account for almost 90 percent of those sentenced to state prisons for drug possession, and that the number of black (non-Hispanic) women incarcerated in state prisons for drug offenses multiplied more than eightfold from 1986 to 1991. Id at 1-2, 13. These disparate conviction rates have all the more impact because drug offenders are sentenced to longer terms (6.5 years on average) than racketeers or extortionists (5 years). Keith W. Watters, Law Without Justice, Natl Bar Assoc Mag 1, 23 (Mar/Apr 1996).

${ }^{18}$ A 1995 public opinion survey found that only 6 percent of the respondents thought that drug abuse is less of a problem today than five years ago. The survey notes that $\mathbf{5 0}$ percent gave the federal government a grade of "D" or "F" for dealing with the problems of drug use and addiction. Eric E. Sterling, Drug Policy of a Failed User, Legal Times 26 (May 22, 1995). See also Eva Bertram and Kenneth Sharpe, War Ends, Drugs Win, The Nation 11 (Jan 6, 1997); William F. Buckley, Jr., et al, Symposium, The War on Drugs is Lost, 48 Natl Rev 34 (Feb 12, 1996); Massing, NY Rev of Books at 42 (cited in note 11); Dan Baum, Smoke and Mirrors: The War on Drugs and the Politics of Failure (Little, Brown 1996).

${ }^{19}$ Then-Surgeon General Elders suggested that drug legalization should be studied as a possible alternative to urban disorder brought about by the War on Drugs. Stephen Labaton, Surgeon General Suggests Study of Legalizing Drugs, NY Times A23 (Dec 8, 1993). Judge Baer suppressed evidence of a large quantity of cocaine and heroin he deemed seized without probable cause. After attacks by the media, Senator Dole, and President Clinton, he reversed his ruling. See Don Van Natta, Jr., Under Pressure, Federal Judge Reverses Decision in Drug Case, NY Times A1 (Apr 2, 1996). Former Governor William 
motive underpinning the Drug War is not. This bureaucratic stake is financial, deriving from the lucrative rewards available to police and prosecutorial agencies that make drug law enforcement their highest priority. It operates invisibly, obscured by moral and policy rationales.

Congress conferred these financial benefits to state and local law enforcement both directly, through block grants earmarked for drug law enforcement, and indirectly, through forfeiture provisions authorizing law enforcement agencies to seize "drugrelated" assets, such as a house in which marijuana plants have been grown, and use the proceeds for their budgetary needs. Together these programs have ensured continued police enthusiasm for the Drug War by offering financial largess unmatched in any other area of law enforcement. But they have also transformed the criminal justice system in two dangerous ways.

First, these programs have distorted governmental policymaking and law enforcement. During the past decade, law enforcement agencies increasingly have turned to asset seizures and drug enforcement grants to compensate for budgetary shortfalls, at the expense of other criminal justice goals. We believe the strange shape of the criminal justice system today-the law enforcement agenda that targets assets rather than crime, ${ }^{20}$ the 80 percent of seizures that are unaccompanied by any criminal prosecution, ${ }^{21}$ the plea bargains that favor drug kingpins and penalize the "mules" without assets to trade, ${ }^{22}$ the reverse stings that target drug buyers rather than drug sellers, ${ }^{23}$ the overkill in agencies involved even in minor arrests, ${ }^{24}$ the massive shift towards federal jurisdiction over local law enforcement ${ }^{25}$-is largely the unplanned by-product of this economic incentive structure.

Weld found his nomination to be Ambassador to Mexico hijacked by Senator Jesse Helms on grounds that Weld had supported proposals to allow the medical use of marijuana. See John F. Harris, Weld Ends Bid to Be Ambassador, Wash Post A1 (Sept 16, 1997). Michael Tonry argues that " $t \mathrm{t}] \mathrm{he}$ War on Drugs and the set of harsh crime control policies ... were undertaken to achieve political, not policy, objectives. It is the adoption for political purposes of policies with foreseeable disparate impacts, the use of disadvantaged black Americans as means to achieving politicians' electoral ends, that must in the end be justified. It cannot." Michael Tonry, Malign Neglect-Race, Crime, and Punishment in America 39 (Oxford 1995). For a discussion of the self-perpetuating nature of public policy that benefits politicians, see Randy E. Barnett, Bad Trip: Drug Prohibition and the Weakness of Public Policy, 103 Yale L J 2593, 2618 (1994) (book review).

${ }^{20}$ See Section II.

${ }^{21}$ See note 155 and accompanying text.

${ }^{2}$ See text accompanying notes 127-36.

${ }^{23}$ See text accompanying notes 118-24.

${ }^{24}$ See text accompanying notes 137-42 and 293-95.

${ }^{25}$ See text accompanying notes $66-69$. 
Second, the forfeiture laws in particular are producing selffinancing, unaccountable law enforcement agencies divorced from any meaningful legislative oversight. There are numerous examples of such semi-independent agencies targeting assets with no regard for the rights, safety, or even lives of the suspects. ${ }^{26}$ Such dire results should prompt reform, particularly because a single measure-one mandating that forfeited assets be deposited in the Treasury's General Fund rather than retained by the seizing agency-would cure the forfeiture law of its most corrupting effects. But thus far the forfeiture industry has enjoyed an astonishing immunity from scrutiny by lawmakers and the courts. ${ }^{27}$

In the following pages, we first describe in more detail how the Drug War's financial largess has kept its soldiers in business. We then discuss the destructive impact of this economic regime, marshaling evidence to show that the corruption of law enforcement priorities and wholesale miscarriages of justice can be attributed to the operation of these incentives. Finally, we explore potential legal and legislative remedies through which law enforcement may regain its bearings.

Our investigation focuses on the economic underpinnings of current drug law enforcement policy. Drug policy also raises an extraordinarily broad range of moral, health, and criminological concerns, which we do not discuss except insofar as the financial incentives we describe have interfered with attempts to address them. We take no position here on such pivotal issues as legalization or decriminalization, but hope to speak to abolitionists and prohibitionists alike. All sides should be able to agree that, at a minimum, the law enforcement agenda should not be held hostage to the opportunities for financial self-aggrandizement we describe herein.

${ }^{26}$ See Sections II.A, III.B.

${ }^{27}$ See United States $v$ One Parcel of Property, 85 F3d 985, 991 n 3 (2d Cir 1996) (“Only one Court of Appeals opinion, a dissent, conducted a full Matthews $v$. Eldridge analysis of the civil drug forfeiture statute's probable cause requirement.") (citations omitted); William S. Genego, Forfeiture, Legitimation and a Due Process Right to Counsel, 59 Brooklyn L Rev 337, 340, 343, 348-56 (1993) (noting that the Second Circuit has consistently "rubber stamped the government's exercise of its forfeiture power ... [unwilling] even to address the merits," and lauding the Second Circuit for having begun a critical reexamination of forfeiture law beginning in 1992); George C. Pratt and William B. Petersen, Civil Forfeiture in the Second Circuit, 65 St John's L Rev 653, 653 (1991) ('Perhaps no area of the law embodies more legal fictions - and better illustrates their use and misuse-than does civil forfeiture."); Steven Wisotsky, Not Thinking Like a Lawyer: The Case of Drugs in the Courts, 5 Notre Dame J Legal Ethics \& Pub Pol 651, 658 (1991) (arguing that courts have adopted "the operative premise ... that 'drugs are bad,' so bad that almost any law or law enforcement measure is validated"). 


\section{THE DRUG WAR DIVIDEND}

Congress continues to pass a new crime bill every few years. Since the $1980 \mathrm{~s}$, these laws have become especially punitive to drug offenders ${ }^{28}$ and increasingly profitable to the law enforcement agencies that pursue them. The latter was accomplished primarily by rewriting existing federal aid and forfeiture laws specifically to promote and finance drug law enforcement. We take each in turn.

\section{A. Federal Aid to Drug Law Enforcement}

In 1986, Congress revised the federal aid program, renaming it the Edward Byrne Memorial State and Local Law Enforcement Assistance Program after a New York City police officer who was shot during a drug arrest. ${ }^{29}$ The Byrne Program replaced the federal block grants previously given to the states by the nowdefunct Law Enforcement Assistance Administration. ${ }^{30}$ Unlike the earlier program, Byrne grant recipients are required to use

${ }^{28}$ The Comprehensive Crime Control Act of 1984, Pub L No 98-473, 98 Stat 1976, codified at 18 USC $\S \S 1$ et seq (1994), The Comprehensive Forfeiture Act of 1984, Pub L No 98473, 98 Stat 2040, codified at 18 USC \$§ 1961-68 (1994), and the Anti-Drug Abuse Act of 1986, Pub L No 99-570, 100 Stat 3207, codified at 21 USC $\$ \S 801$ et seq (1994), added new forfeiture laws and new civil penalties, among many stringent provisions. Drug sentences were ratcheted up fairly continuously; one year's "get tough" provisions were deemed too lenient the next. The 1986 Act prescribed some of the harshest sentences in the United States Code: five-year mandatory minimum sentences for sale of small amounts of drugs, and mandatory ten-years-to-life sentences for those convicted of possession with intent to distribute larger quantities of drugs, such as ten grams of LSD. 21 USC § 841(b) (1994).

In 1988, Congress doubled many of the penalties in the earlier law and eliminated probation or parole in most cases. Anti-Drug Abuse Amendments Act of 1988, Pub L No 100-690, 102 Stat 4312, codified at 21 USC $\S 801$ et seq (1994). See, for example, 21 USC $\S \S 841(\mathrm{~d}), 848(\mathrm{a})$. This 1988 Act also increased the penalty for simple possession of crack cocaine to a minimum five-year prison term. 21 USC \$ 844 (1994).

In 1994, Congress passed the Violent Crime Control and Law Enforcement Act, which included new death penalty offenses and limits on habeas corpus proceedings. Violent Crime Control and Law Enforcement Act of 1994, Pub L No 103-322, 108 Stat 1796, codified at 42 USC §§ 13701 et seq (1994); Federal Death Penalty Act of 1994, Pub L No 103322, 108 Stat 1959, codified at 18 USC § 3591 (1994). See also Wisotsky, 5 Notre Dame J Legal Ethics \& Pub Pol at 654, 679 (cited in note 27) (discussing increased enforcement measures, and lamenting their failure); Michele H. Kalstein, Kirstie A. McCormack, and Seth A Rosenthal, Comment, Calculating Injustice: The Fixation on Punishment as Crime Control, 27 Harv CR-CL L Rev 575, 575-78 (1992) (discussing the shift from individual rehabilitation to system-wide "obedience").

This program is authorized by the Anti-Drug Abuse Act of 1986 as amended in 1988. Pub L No 100-690, 102 Stat 4329, codified at 42 USC $\$ \$ 3750-55$ (1994).

${ }^{30}$ The Law Enforcement Assistance Administration provided $\$ 7.7$ billion to state and local governments between 1968 and its expiration in 1982. What the L.E.A.A. Elephant Learned, NY Times A22 (Apr 21, 1982). 
these funds to fight the War on Drugs. ${ }^{31}$ The Byrne Program is now the primary federal program that funds state and local drug law enforcement.

Byrne grants have altered the law enforcement landscape in numerous ways, most notably in the proliferation of multijurisdictional drug task forces ("MJDTFs"), ${ }^{32}$ now collectively the largest funding category in the federal aid program. ${ }^{33}$ Between 1988 and 1991, the number of Byrne-funded task forces almost doubled to 904 task forces covering 83 percent of the population, ${ }^{34}$ with up to sixty-three multijurisdictional task forces operating within individual states. $^{35}$ MJDTF drug arrests fluctuated between 220,000 and 280,000 annually during this period. ${ }^{36}$ (See Figure 1.)

${ }^{31}$ These grants are administered by the Bureau of Justice Assistance ("BJA") office "to assist States and units of local government in carrying out specific programs which offer a high probability of improving the functioning of the criminal justice system ... by developing programs and projects to assist multijurisdictional and multi-State organizations in the drug control problem and to support national drug control priorities." 42 USC $\S 3751$ (a) (1994). The money goes to the requesting state, where it is distributed by the state's criminal justice agency to individual or combined units of state or local government.

${ }^{32}$ A multijurisdictional task force is supposed to enable law enforcement agencies to collaborate across state, local, and national boundaries on drug investigations, arrests, seizures, information gathering, and surveillance.

${ }^{33}$ Of the twenty-one program areas eligible for federal block grant assistance, multijurisdictional drug task forces have consistently garnered approximately one-third of the funding each year. Over half of that amount finances the salaries and overtime pay of task force members. General Accounting Office ("GAO"), War on Drugs, Federal Assistance to State and Local Drug Enforcement 1, 5 (1993). In 1991, \$139 million of Byrne money funded 881 MJDTFs with amounts allocated to each state from $\$ 111,000$ to more than $\$ 23$ million. Id at 5. See also JRSA, Multijuridictional Drug Enforcement Task Forces: A Special Analysis Report of the National Consortium to Assess State Drug Control Initiatives 22 (June 1992) (reporting that "approximately 40 percent of BJA formula grant funds were allocated to establish or enhance drug enforcement task force operations"); James Coldren, Jr., et al, Multijurisdictional Drug Task Force Operations: Results of a Nationwide Survey of Task Force Commanders 1 (1993) (reporting that 50 percent of the BJA formula grants were allocated to MJDTFs).

31 JRSA, Special Analysis Report at 22 (cited in note 33). Ninety-one percent of task forces were created from 1987 to 1992 . "This corresponded to the availability of federal funds for task forces ...." Coldren, et al, Nationwide Survey at 5 (cited in note 33).

${ }^{35}$ JRSA, Five-Year Review at 6 (cited in note 1). These statistics include only Byrne formula grant-funded task forces. There are many other federally funded drug task forces outside the Byrne grant program as well, such as the Organized Crime Drug Enforcement Task Forces ("OCDETF"), the DEA task forces, and the Bureau of Justice Assistance discretion grant funded task forces. Id at 5. Fifty-two localities have both DEA- and Byrnefunded task forces. See GAO, War on Drugs at 1 (cited in note 33). The DEA also deploys Mobile Enforcement Teams ("METS"), groups of ten to twelve DEA agents, each assigned to a local police department. Federal Law Enforcement Priorities Hearings at 51-52 (statement of Constantine) (cited in note 10).

${ }^{36}$ JRSA, Five-Year Review at 6-7 (cited in note 1). 


\section{Total MJDTF Arrests, 1988-1992}

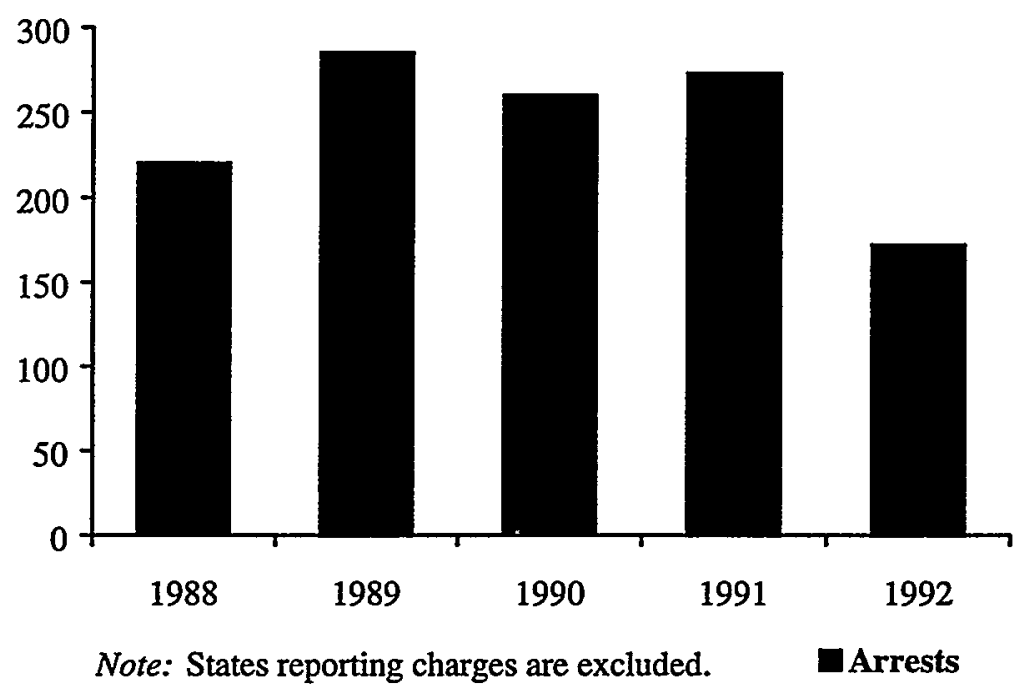

Figure $\mathbf{1}^{37}$

B. Forfeiture and Asset Distribution

Modern drug forfeiture laws date from 1970, when Congress passed the Comprehensive Drug Abuse Prevention and Control Act. ${ }^{38}$ The Act included a civil forfeiture provision, 21 USC $\S 881$, authorizing the government to seize and forfeit drugs, drug manufacturing and storage equipment, and conveyances used to transport drugs. ${ }^{39}$ This provision was intended to forestall the spread of drugs in a way criminal penalties could not-by striking at its economic roots. When criminal prosecution sends a drug dealer to jail, a subordinate will most likely take his place, but seizing the means of production and other capital may shut down the trafficking business for good. In the twenty-seven years since, the list of properties subject to forfeiture has expanded greatly,

${ }^{37}$ JRSA, Five-Year Review at 5 (cited in note 1).

${ }^{33}$ Pub L No 91-513, 84 Stat 1242 (1970), codified at 21 USC $\S 801$ et seq (1994). Congress passed other major forfeiture legislation in 1970 as well. It inserted forfeiture provisions in the Racketeer Influenced and Corrupt Organizations ("RICO") Act. Organized Crime Control Act of 1970, Pub L No 91-452, 84 Stat 943, codified at 18 USC §§ 1961-68 (1994).

${ }^{39} 21$ USC \& 881(a). Criminal forfeiture, covering proceeds or instrumentalities of a federal drug felony, is governed by 21 USC $\S 853$. 
and the required connection to illegal drug activity has become ever more remote. Over the years, Congress expanded the forfeiture law to include proceeds traceable to drug transactions ${ }^{40}$ and real property, ${ }^{41}$ and in 1986 Congress promulgated a "substitute assets" law allowing property of equal value to be forfeited in place of forfeitable assets that are no longer available. ${ }^{42}$ Today cash, bank accounts, jewelry, cars, boats, airplanes, businesses, houses, and land are all fair game.

This wholesale expansion of targets has produced enormous confusion as to what kind of nexus to a drug violation will suffice. The law provides for forfeiture of property that "facilitated" a drug crime, ${ }^{43}$ but courts have developed no clear criteria for defining facilitation. ${ }^{44}$ Some police, prosecutors, and judges construe

*0 Psychotropic Substances Act of 1978, Pub L No 95-633, 92 Stat 3768, codified at 21 USC $\S 881(a)(6)$ (1994). Proceeds are broadly defined to include cash, negotiable instruments, securities, and other things of value. This amendment resulted in a twentyfold increase in the value of DEA forfeitures compared to the previous year. GAO, Asset Forfeiture-A Seldom Used Tool in Combating Drug Trafficking 59 (1981). The GAO report also notes that during the ten years following the enactment of RICO and Continuing Criminal Enterprise forfeitures in 1970 , these forfeiture provisions were used in only ninety-eight cases. Id at 7.

41 Pub L No 98-473, 98 Stat 2050 (1984), codified at 21 USC § 881(a)(7) (1994) (authorizing forfeiture of real property used, or intended to be used, to commit or facilitate a federal drug felony). There is legislative history suggesting seizable property was conceived as property actually used in manufacturing drugs. See William Patrick Nelson, Comment, Should the Ranch Go Free Because the Constable Blundered? Gaining Compliance with Search and Seizure Standards in the Age of Asset Forfeiture, $80 \mathrm{Cal} \mathrm{L} \mathrm{Rev} \mathrm{1309,}$ 1315-16 (1992), citing GAO, Asset Forfeiture at 13, 59 (cited in note 40). However, courts and prosecutors have interpreted it broadly to include any real property having a connection to a drug offense punishable by a year in prison. Id.

42 Anti-Drug Abuse Act of 1986, Pub L No 99-570, 100 Stat 3207-13, codified at 21 USC \& 853(p) (1994).

${ }^{43} 21$ USC $\$ 853(a)(2)$. The drug offense must be punishable by more than one year's imprisonment to serve as a predicate for forfeiture. 21 USC $\$ 853($ a). Only simple possession crimes fall below this threshold. 21 USC \$ 844(a).

4 Compare the construction of 21 USC $\$ 881$ (a)(7) (discussing forfeiture of real property that, inter alia, facilitates a narcotics felony) in United States $v$ Santoro, 866 F2d 1538,1542 (4th $\mathrm{Cir} 1989$ ) (requiring a substantial connection between the property and the felony), with that in United States $v$ Real Estate Known as 916 Douglas Avenue, 903 F2d 490, 493-94 (7th Cir 1990) (affirming forfeiture when property is used "in any manner or part," as long as more than "incidental or fortuitous").

David B. Smith, former Associate Director of the Department of Justice's Asset Forfeiture Office, notes that the various tests used by different courts to define facilitation- “active aid," "some substantial connection to" a transaction, making a transaction "less difficult" - "merely beg the question posed by the statutory language, rather than answering it." David B. Smith, Prosecution and Defense of Forfeiture Cases Release 16 II 3.03 at 3-13 to 3-14 n 6 (Matthew Bender June 1995). Is a car forfeitable because it was used to drive to a preliminary meeting that led to a drug transaction on a later date? See United States $v$ One 1974 Cadillac Eldorado Sedan, 548 F2d 421, 423 (2d Cir 1977) (finding nexus sufficient). Is any quantity of drugs, however minute, sufficient to justify forfeiture of an 
this as a license to proceed on the most tenuous of grounds-for example, seeking to forfeit a bar for the owner's failure to stop drug dealing within, ${ }^{45}$ or a house in which the owner's son sold drugs, ${ }^{46}$ or cash on which some cocaine residue has been found. ${ }^{47}$

For prosecutors, the expanding reach of the forfeiture law is complemented by the great procedural and financial benefits it offers. Procedurally, two tremendous advantages accrue to the government from an ancient legal fiction that dominates all for-

automobile? See United States v One 1986 Mercedes Benz, 846 F2d 2, 4-5 (2d Cir 1988) (finding less than one ounce of marijuana sufficient for forfeiture). Must the government link the property to a specific drug transaction? See United States $v$ Banco Cafetero Panama, 797 F2d 1154, 1160 (2d Cir 1986) (answering no, so long as the government can link the property with drug activity). These rulings are worrisome if the justification for denying criminal due process rights is that the forfeiture is an action against the guilty property based on its close relationship to the criminal activity. See Austin $v$ United States, 509 US 602, 623-27 (1993) (Scalia concurring) (rejecting a claim that forfeiture constitutes a "punishment" that would bring it under the Eighth Amendment). They are also troubling, however, because disproportionate, if forfeiture is supposed to be based on the culpability of the owner, as the majority suggested in Austin. See id at 615 (Forfeiture rests "on the notion that the owner has been negligent in allowing his property to be misused and . . . is properly punished for that negligence.").

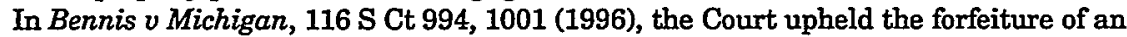
automobile that was the site of an act of prostitution against a claim by the client's wife. Finding insufficient nexus and noting that the car fit none of the traditional categories of goods subject to seizure-contraband, proceeds of criminal activity, or tools of the criminal's trade-Justices Stevens, Souter, and Breyer dissented, and criticized what they viewed as the Court's grant of unbridled governmental power to confiscate private property with only a tangential relationship to a crime. Id at 1007-08, 1010 (Stevens dissenting). Justice Thomas, concurring in Bennis, noted that the Court has yet to delineate what it means in the context of forfeiture law for someone to "use" property. He urged that the limits be strictly construed when the government contemplates taking property from those it merely suspects of colluding in crime, or from those it does not even suspect. Id at 1002 (Thomas concurring).

t5 Judy Rakowsky, State tries to seize Weymouth bar in drug case, Boston Globe C11 (Oct 18, 1996) (reporting the Massachusetts Attorney General's filing of a civil suit to forfeit the bar "for allegedly failing to stop drug dealing in the bar").

${ }^{46}$ United States $v$ Real Property at 6625 Zumirez Drive, 845 F Supp 725 (C D Cal 1994). The court found against the government, holding that in the circumstances of the case, forfeiture of the father's home of twenty-two years for the acts of his son was an excessive fine barred by the Eighth Amendment. Id at 740-42.

${ }^{17}$ Police had seized money in the absence of drugs, later confirming through laboratory analysis that it contained some residue of cocaine. Although only a small percentage of paper currency is actually used for packaging and sniffing cocaine, because "the minutest trace of the drug will 'infect' other bills, much of the currency in the country now tests positive for narcotics." David Heilbroner, The Law Goes on a Treasure Hunt, NY Times $\$ 6$ at 70 (Dec 11, 1994). Courts have split in their treatment of drug-contaminated currency. Compare United States v US Currency, $\$ 30,060.00,39$ F3d 1039, 1042-43 (9th Cir 1994) (noting widespread contamination of bills, and finding continued reliance on cocaine detection dogs indefensible), with United States $v \$ 67,220.00$ in United States Currency, 957 F2d 280, 285 (6th Cir 1992) (holding that positive dog identification is evidence of currency's connection to drugs). 
feiture cases-that the property is guilty and on trial. ${ }^{48}$ This means, first, that forfeiture can be used even when there is insufficient evidence for a criminal case or when the defendant is a fugitive. The government need only seize the assets, ${ }^{49}$ and it is then up to the owner to challenge the seizure in a costly and unpromising hearing. ${ }^{50}$

Second, as a "civil action" against the property itself ${ }^{51}$ (as in United States $v$ One 1974 Cadillac Eldorado Sedan ${ }^{52}$ ), few of the constitutional safeguards imposed on criminal prosecutions ap-

${ }^{2}$ The proceedings are instituted against tainted property as a civil in rem proceeding, based on the idea that the property is guilty and not the owner. See J.W. Goldsmith, Jr.Grant Co $v$ United States, 254 US 505, 511 (1921) (calling in rem actions "firmly fixed in the punitive and remedial jurisprudence of the country"); The Palmyra, 25 US (12 Wheat) 1,14 (1827) (enforcing a statutory in rem forfeiture of a sailing ship in the absence of a personal conviction because "the offence is attached primarily to the thing"); United States $v$ The Little Charles, 26 F Cases 979, 982 (D Va 1818) (enforcing in rem forfeiture even though "inanimate matter can commit no offence"). The concept was borrowed from English and biblical law and adapted for use in America during the colonial period. In England, deodand, which made the instrumentality of someone's death forfeitable to the crown, is often cited as a predecessor of civil forfeiture, although the claim is not without doubt. Compare James Maxeiner, Note, Bane of American Forfeiture Law-Banished at Last?, 62 Cornell L Rev 768, 771-81 (1977) (arguing that in rem forfeitures derive not from deodand, but from English statutory forfeitures of vessels violating customs and revenue laws), and Calero-Toledo $v$ Pearson Yacht Leasing Co, 416 US 663, 682-83 (1974) (noting that deodands did not become part of American common law, but that English forfeiture statutes were enforced by American courts), with Oliver Wendell Holmes, Jr., The Common Law 24-34 (Little, Brown 1944) (linking in rem proceedings to principles of early English deodand law), and Jacob J. Finkelstein, The Goring Ox: Some Historical Perspectives on Deodands, Forfeitures, Wrongful Death and the Western Nation of Sovereignty, 46 Temple L Q 169, 182-83 (1973) (analogizing deodands to forfeiture to the Crown).

49 The general rule is that "seizure for purposes of forfeiture is one of those "extraordinary situations' that justify postponing notice and opportunity for a hearing" until after seizure. Calero-Toledo, 416 US at 677, citing Fuentes $v$ Shevin, 407 US 67, 90 (1972). However, an exception is made in the case of real estate because, unlike other assets, it is not removable, and there are other, less drastic ways to secure it pending a preseizure hearing. United States $v$ James Daniel Good Real Property, 510 US 43, 57 (1993). There, the Court applied the three-pronged procedural due process test of Mathews $v$ Eldridge, 424 US 319, 335 (1976), weighing the private interest affected, the risk of erroneous deprivation under the process used, and the government's interest in avoiding more burdensome procedures. James Daniel Good, 510 US at 53. As the Court noted, one consequence of having no preseizure hearing is that the magistrate issuing the warrant will not be informed of possible defenses to forfeiture, such as innocent ownership, leading to prolonged, erroneous deprivation. Id at 55-56.

${ }^{50}$ To do so the owner must post a cash bond of 10 percent of the appraised value, up to $\$ 5,000$, within twenty days of notification of the intended forfeiture. Law of June 17, 1930, ch 497, title IV, $\S 608,46$ Stat 755, codified at 19 USC $\$ 1608$ (1994). Ordinarily the owner will need to retain a lawyer as well.

${ }^{51}$ As an in rem action, a forfeiture proceeding establishes government title to the property against all claimants. Criminal forfeitures are in personam actions that determine the governments rights to the property only against the defendant. Smith, Forfeiture I 2.03 at $2-10$ (cited in note 44 ).

${ }^{82} 548$ F2d 421 (2d Cir 1977). 
ply. ${ }^{53}$ There is no presumption of innocence, no right to an attorney, and no hearsay objection. ${ }^{54}$ The burden of proof is reversed: once the government establishes probable cause that the property is subject to forfeiture, the burden shifts to the property owner to prove by a preponderance of the evidence that the property does not belong to the government. ${ }^{55}$ There is no constitutional requirement that the property owner be at fault, ${ }^{56}$ or be prosecuted

s3 Some of the procedural inadequacies may be addressed by Congress in the coming year. See text accompanying notes 271-75. In any event, among the few constitutional safeguards that apply (in substantially weakened form) are the Fourth Amendment right against unreasonable searches and seizures, the Fifth Amendment privilege against self incrimination and, as detailed in Section IV, the Eighth Amendment prohibition on excessive fines. See Boyd $v$ United States, 116 US 616, 634 (1886) (characterizing civil forfeiture as "quasi-criminal" for purposes of Fourth and Fifth Amendments). Even here, however, the rights bear little resemblance to their criminal law cousins. In contrast to a criminal trial, in a civil forfeiture case the government may be able to rely on a negative inference from the claimant's assertion of the Fifth Amendment privilege. See discussion in Smith, Forfeiture II 10.03 at 10-14 to 10-49 (cited in note 44) (citing conflicting authority and concluding that the question remains open); United States $v$ Property Located at 15 Black Ledge Drive, 897 F2d 97, 103 (2d Cir 1990) (declining to resolve conflicting authority on the permissibility of adverse influences in civil forfeiture proceedings, and noting the issue of parallel criminal charges as "troubling"). As to the Fourth Amendment, the exclusionary rule may apply to seized evidence, see One 1958 Plymouth Sedan v Pennsylvania, 380 US 693, 702 (1965), but will not serve to suppress seized items that are themselves subject to forfeiture. See INS v Lopez-Mendoza, 468 US 1032, 1039-40 (1984) (suggesting rule was already in existence); United States $v \$ 12,390,956$ F2d 801, 806 (8th Cir 1992) (following INS v Lopez-Mendoza); United States $v \$ 37,780$ in United States Currency, 920 F2d 159, 163 (2d Cir 1990) (same). For a discussion of the troubled relationship between forfeiture laws and Fourth Amendment protections, see Nelson, 80 Cal L Rev at 1333-45 (cited in note 41).

54 Lassiter $v$ Department of Social Services, 452 US 18, 26-27 (1981) (stating presumption that individual has no right to appointed counsel unless his physical liberty is at stake); United States v Property at $\$ 492$ S Livonia Rd, 889 F2d 1258, 1267 (2d Cir 1989) (no hearsay objection); Smith, Forfeiture II 11.03 at 11-13 (cited in note 44) (no presumption of innocence).

ss Act of June 17, 1930, ch 497, title IV, $\S 615,46$ Stat 757, codified at 19 USC $\S 1615$ (1994). In United States $v \$ 12,390,956$ F2d at 810, Judge Beam, dissenting, concluded that the government's ability to divest a claimant of title "with a mere probable cause showing, often established through the use of inadmissible evidence ... [is] a denial of due process." Dicta in some Second Circuit and Ninth Circuit opinions also have questioned whether shifting the burden of proof to the defendant comports with due process. See United States v 49,576 US Currency, 116 F3d 425, 428 (9th Cir 1997); United States $v$ One Parcel of Property Located at 194 Quaker Farms Road, 85 F3d 985, 990-91 (2d Cir 1996). Regarding the burden of proof, see also United States $v$ Eighty-Seven Thousand Sixty Dollars, 23 F3d 1352, 1354 (8th Cir 1994); United States v \$121,100 in US Currency, 999 F2d 1503, 1505 (11th Cir 1993).

${ }^{36}$ Goldsmith, 254 US at 513; Calero-Toledo, 416 US at 680. Calero-Toledo held forfeiture constitutional against an innocent, nonnegligent owner. However, it left open a possible constitutional defense for those who have done everything that reasonably could be expected to prevent the proscribed use of the property. Id at 689-90. Particularly draconian results flow from the "relation back doctrine" except in those jurisdictions that have abolished it. Under the doctrine, title to the property passes to the government at the time 
for the underlying criminal activity. Forfeiture may occur even if the owner is charged and acquitted..$^{57}$ (Of course, given the rapid expansion of forfeitable targets to include homes, money, and businesses, often the only "taint" on non-contraband property is its owner's alleged wrongdoing. ${ }^{58}$ In such cases forfeiture is hardly distinguishable from punishment without trial-_a deliberate subterfuge ${ }^{n 59}$ that has been analogized to Soviet-era punishment of political offenders under "non-criminal" laws, which existed to deprive people of their criminal procedural rights. ${ }^{60}$ )

of the act, making it subject to forfeiture. It may be years before the government takes any action against the property or the owner, and in the interim it may have been sold to an innocent third party. Thus under this doctrine, the government may defeat the claim of a bona fide purchaser. This doctrine is presumed, but may be altered by specific legislative enactment, for example, by providing for transfer of title when the property is seized. See, for example, Motlow v State, 295 US 97, 99 (1935); United States v Stowell, 133 US 1, 12 18 (1890); Henderson's Distilled Spirits, 81 US (14 Wall) 44, 56-64 (1871). Congress codified the relation back doctrine in the Comprehensive Forfeiture Act of 1984, but has also amended Section 881 to protect the interests of innocent owners in federal forfeitures, The Anti-Drug Abuse Act of 1988, Pub L No 100-690, $\S 6075,102$ Stat 4324, codified at 21 USC $\S 881(a)(4)(c)$ (1994), and has further provided an opportunity to mitigate unjust cases through an administrative remission process. For further discussion of the need to provide fair proceedings, see also Bennis v Michigan, $116 \mathrm{~S} \mathrm{Ct} 994$ (1996), discussed in note 44.

${ }^{57}$ United States $v$ One Assortment of 89 Firearms, 465 US 354, 361-62 (1984) (holding that acquittal does not estop civil forfeiture action because civil proceedings have lower burdens of proof). The Supreme Court disposed of any double jeopardy claim against successive criminal and forfeiture proceedings or punishments by holding that although in rem forfeiture is both remedial and punitive in nature, it is not so punitive as to equal a second punishment. United States v Ursery, 116 S Ct 2135, 2142-49 (1996).

${ }^{38}$ See 6625 Zumirez Drive, 845 F Supp at 737 ("The mere fact that the criminal activity occurred at the property does not make the property 'guilty' of an offense, 'as could reasonably be argued of [a] distillery . . . or [a] pirate vessel' . . . .") (citations omitted); Pratt and Peterson, 65 St John's L Rev at 655, 668 (cited in note 27) ("[T]he scope of civil forfeiture has been expanded to function as punishment for the property owner's criminal conduct, while the doctrine continues to masquerade as a civil proceeding against property .... Congress has created a draconian punishment that is virtually bereft of constitutional protections.").

so Finkelstein, 46 Temple L Q at 252 (cited in note 48). See also United States $v$ All Assets of Statewide Auto Parts, Inc, 971 F2d 896, 905 (2d Cir 1992) ("We continue to be enormously troubled by the government's increasing and virtually unchecked use of the civil forfeiture statutes and the disregard for due process that is buried in those statutes."); Boyd, 116 US at 637, in which the Supreme Court rejected the "proposition that the [in rem] proceeding is not, in effect, a proceeding against the owner of the property, as well as against the goods; for it is his breach of the laws which has to be proved to establish the forfeiture, and it is his property which is sought to be forfeited." In today's Court, Justice Stevens is especially critical of the Rehnquist Court's reliance on the fiction, sometimes called the personification doctrine, that forfeiture is a civil action only against property. See Ursery, $116 \mathrm{~S} \mathrm{Ct}$ at 2160-61 (Stevens dissenting) (calling it a "sleight of hand" and noting that "formalistic distinctions that obscure the obvious practical consequences of governmental action disserve... the Double Jeopardy Clause").

${ }^{60}$ Smith, Forfeiture II 1.02 at 1-16 to 1-17 (cited in note 44). A Ninth Circuit opinion notes its wariness of civil forfeiture because it imposes "quasi-criminal" penalties without affording criminal procedural protections. United States $v \$ 191,910.00$ in US Currency, 16 
Given these inadequate safeguards, it is not surprising that roughly 90 percent of judicial cash forfeitures are uncontested. ${ }^{61}$ Congress handed police and prosecutors a powerful tool, and law enforcement's interest in using it accelerated when Congress enacted two additional amendments to the forfeiture law. One amendment, part of the 1984 bill, allowed federal law enforcement agencies to retain and use the proceeds from asset forfeitures, rather than requiring these assets to be deposited in the Treasury's General Fund. ${ }^{62}$ The other initiated the federal "equi-

F3d 1051, 1068 (9th Cir 1994). See also Juan R. Torruella, The "War on Drugs": One Judge's Attempt at a Rational Discussion, 14 Yale J Reg 235, 256 (1997) ("Some of the most egregious actions committed by the government have been in the area of forfeitures, in which courts have allowed abuses which seriously undermine principles of legality and due process."). For an early example of punishment in the guise of an in rem, noncriminal proceeding against property, see Miller $v$ United States, 78 US (11 Wall) 268, 304-06 (1871) (upholding the civil forfeiture of estates of Confederate rebels as constitutional under the power to prosecute war). A dissenting opinion argued that such confiscation was effectively punishment for treason, which should only be applied after criminal prosecution. Id at 318-23 (Field dissenting). See also Tyler $v$ Defrees, 78 US (11 Wall) 331, 351-53 (1871) (Field dissenting).

${ }^{61}$ GAO, Asset Forfeiture: An Update 7 (Apr 24, 1989) (submitted to the Subcommittee on Crime of the House Judiciary Committee) (reporting that, in its 1989 analysis of 1,125 Justice Department and Customs forfeitures, 89 percent of judicially forfeited cash was uncontested, resulting in default judgments for the government). Although a claimant may also seek mitigation of a forfeiture judgment from the Attorney General, the odds here are even more daunting: the Justice Department refunded only $\$ 13$ million of the $\$ 460$ million in assets that it sought to forfeit in 1990. Federal Seizure of Illegal Assets Nets Government $\$ 1.5$ Billion Since 1985, USLW (Feb 4, 1991). Consequently, the best alternative for most claimants is to seek an agreement with the government to return some portion of the seized property. While this often occurs, the government has a substantial advantage in negotiation and the deal struck may instead exchange a prosecutorial commitment not to pursue criminal charges for the claimant's waiver of rights to all the property, or even for a commitment to turn over additional property. At the time the GAO's analysis was undertaken, four-fifths of the cases examined were judicial forfeitures, and less than one-fifth administrative forfeitures, because administrative forfeitures could not be instituted against real estate or against assets worth over $\$ 100,000$. GAO, Asset Forfeiture: Update at 1, 7. But the ceiling has since been raised to $\$ 500,000$, resulting in a huge shift to administrative forfeitures. Eighty percent of federal forfeitures now occur administratively. Steven L. Kessler, Civil and Criminal Forfeiture: Federal and State Practice $\S 6.01$ at 6-2 to 6-4 (Clark Boardman Callaghan 1996).

62 Comprehensive Crime Control Act of 1984, Pub L No 98-473, 98 Stat 2052, codified at 28 USC $\$ 524$ (1994). Although the Department of Justice Assets Forfeiture Fund was initially required to deposit to the Treasury's General Fund all sums in excess of $\$ 5$ million that remained after authorized payments, this ceiling was abolished by a 1986 amendment. Department of Justice Assets Forfeiture Fund Amendments Act of 1986, Pub L No 99-570, 100 Stat 3207-12, codified at 28 USC \& 524(c)(4) (1994). Pursuant to 21 USC $\S 881(\mathrm{e})(2)(\mathrm{A})-(\mathrm{B})$, whenever money is seized by a purely federal agency other than the postal service, the agency may keep the expenses related to the seizure, and must transfer the rest to the Department of Justice Assets Forfeiture Fund. This Fund is earmarked for law enforcement. It may not be used to pay the salaries of United States employees, but may be used to pay informants for information, or to pay salaries of local police or other nonfederal employees. 28 USC $\S 524(\mathrm{c})(1)(\mathrm{F})$; Directive 90-5, The Attorney-General's 
table sharing" program, which gave the state and local police agencies the lion's share of seized assets even when federal agents were involved in the arrest. ${ }^{63}$ The equitable sharing program includes a "federal adoption" procedure, whereby state police who turn seized assets over to the Justice Department for "federal forfeiture" receive back up to 80 percent of the assets' value, to be used exclusively for law enforcement purposes. ${ }^{64}$

These amendments have had two rather immediate consequences relevant to our inquiry. First, they have given state and local police an enormous economic stake in the federal forfeiture law. At a time when state and local government budgets are shrinking, equitable sharing offers a new source of income, limited only by the energy police and prosecutors are willing to commit to seizing assets. ${ }^{65}$ Second, the amendments have produced a major shift toward federal jurisdiction over local law en-

Guidelines on Seized and Forfeited Property (July 1990), in DOJ Asset Forfeiture Manual B-541, B-549 to B-551 (Prentice Hall 1994).

* The Attorney General may share forfeited property with any state or local law enforcement agency that participated in any act leading to seizure or forfeiture of the property, as authorized by 21 USC $\S 881(\mathrm{e})(1)(A)$ and 19 USC $\S 1616 \mathrm{a}(\mathrm{c})$, and, with regard to money laundering violations, 18 USC $\S 981(\mathrm{e})(2)$.

* Seizures accomplished exclusively by state or local agencies may be "adopted" by the federal government whenever the conduct giving rise to the seizure is in violation of federal law. Directive 90-5, in DOJ Asset Forfeiture Manual at B-545 (cited in note 62). When the federal government has "adopted" a state forfeiture case, 80 percent of judicially or administratively forfeited assets are allocated to the state or local agencies for law enforcement purposes, and 20 percent remain with the federal government. In joint seizures, the share is allocated on a case-by-case determination based on the amount of work each agency performed. 21 USC § 881(e)(3); A Guide to Equitable Sharing of Federally Forfeited Property for State and Local Law Enforcement Agencies 7-8 (DOJ Mar 1994). The Justice Department requires state and local agencies receiving equitable sharing funds to use them for law enforcement purposes including, but not limited to, payments for law enforcement equipment, weapons, salaries and overtime, training, expenses for travel, informant reward money, and detention facilities. Guide to Equitable Sharing at 10-11. State and local prosecutors also may receive equitable sharing under specified conditions, which include preparing documents or providing an informant. Id at 8-9. States must request equitable sharing within sixty days of seizure or, if the seizure was federally adopted, within sixty days of the date of adoption. Id at 6 .

${ }^{66}$ For example, the Little Compton, Rhode Island Police Department acquired assets of more than ten times its annual budget through participation in a single operation. Steve Stecklow, Big Money for a Tiny Police Force, Phil Inq A1 (Aug 24, 1992). Such individual forfeitures in the millions are not uncommon. See, for example, United States $v$ Cauble, 706 F2d 1322 (5th Cir 1983) (concerning a multimillion dollar RICO forfeiture of marijuana smuggler's businesses). The largest forfeitures, however, have emanated from securities law forfeitures. See Sharon Walsh, Give and Take on the Hot Issue of Asset Forfeiture, Wash Post F7 (Mar 11, 1996) (listing a \$222 million forfeiture in the Drexel Burnham case and a $\$ 176.3$ million forfeiture in the Michael Milken case). For a discussion of law enforcement's substantial economic stake in forfeited assets, see text accompanying notes 100-14. 
forcement, because "federalizing" a forfeiture is now a more profitable course for both state and local criminal justice bureaucracies. For many state and local police departments, federal forfeiture allows the retention of a far larger portion of the assets (up to 80 percent) than they would receive by proceeding under their own state forfeiture laws, which generally require sharing with other, non-law enforcement state agencies. ${ }^{66}$ Federal adoption is

${ }^{66}$ Listed below are the percentages of forfeited assets made available for law enforcement under the various state forfeiture distribution statutes. Most state laws provide the police with a less favorable percentage of the assets than federal law, or require sharing the assets with other state agencies. Some states, such as Indiana and Missouri, require seized assets to be paid into the state's general fund or some non-law enforcement agency, with none earmarked for police. Ind Code Ann $\S 16-42-20-5$ (e) (West 1997) (All proceeds from forfeiture in excess of expenses are paid into the common school fund of the state.); Mo Const, Art IX, § 7; Mo Ann Stat § 513.623 (Vernon Supp 1997) (Proceeds of all forfeitures are distributed to the schools.). Under equitable sharing of federally adopted seizures, however, 80 percent of federally forfeited assets may be redistributed to the state and local law enforcement agencies. 21 USC \& 881(e)(3) (see note 64 for percentages). See also Directive 90-5, in DOJ Asset Forfeiture Manual at B-545 (cited in note 62).

The percentage of forfeited assets distributed to law enforcement according to each state law is as follows: Ala Code $\S 20-2-93$ (e) (1990) (Distribution is based on contribution to seizure.); Alaska Stat $\$ 17.30 .122$ (1996) (Distribution is at the discretion of the commissioner of administration, within specified limits.); Ariz Rev Stat Ann § 13-4315 (Michie 1997) (Balance of forfeiture proceeds are paid into state or local antiracketeering fund, for reimbursements for forfeiture costs, informants, and injured persons as specified.); Ark Stat Ann § 5-64-505(k) (1993) (Distribution of up to $\$ 250,000$ is based on contribution to seizure, and any excess is to be spent at the discretion of the state drug director.); Cal Health \& Safety Code § 11489(a)(2)(A) (West 1997) (65 percent); Colo Rev Stat Ann § 1613-506 (West 1997) (After costs of forfeiture sale, 10 percent goes to judiciary, 10 percent to state law enforcement, 1.5 percent to the district attorney, and the balance to the seizing agency.); Conn Gen Stat Ann \$\$ 54-36h(f), 54-36i(c) (West 1997) (70 percent goes to the Department of Public Safety and local police departments.); 16 Del Code Ann § 4784(f)(3) (1995) (100 percent); DC Code Ann § 33-552(d)(4)(B) (1993) (100 percent); Fla Stat Ann $\S 932.7055(3)-(6)$ (West 1996) (Distribution method varies depending on the seizing agency, but may not be spent on normal operating expenses of the law enforcement agency.); Ga Code Ann § 16-13-49(u)(4)(B) (Michie 1996) (Distribution is based on contribution to seizure, except state agencies are capped at 25 percent of proceeds.); Hawaii Rev Stat \& 712A-16(2)(a) (1993) (25 percent up to a maximum of $\$ 3$ million per year); Idaho Code § 37-2744(e)(2)(C) (1994) (100 percent); ILCS ch 720, \$§ 550/12(g), 570/505(g) (1997) (Distribution formula under the Cannabis Control Act and the Controlled Substances Act gives 10 percent to the state police, 25 percent to state's attorney, and 65 percent to police narcotics law enforcement fund.); ILCS ch 725, § 175/5(g)-(h) (1997) (Distribution formula under the Narcotics Profit Forfeiture Act gives 25 percent to the state police, 25 percent to the state's attorney, and $\mathbf{5 0}$ percent to law enforcement, but if indictment is under the Statewide Grand Jury Act, 15 percent goes to the state's attorney, 25 percent to drug education, treatment, and prevention programs, and 60 percent to law enforcement.); Ind Code Ann $\$ 16-42-20-5(\mathrm{e})$ (West 1997) (All proceeds from forfeiture in excess of expenses are paid into the common school fund of the state.); Iowa Code Ann \$§ 809A.16-809A.17 (West Supp 1997) (Forfeiture is to the state without discussion of distribution.); Kan Stat Ann § 60-4117(c)-(d) (1994) (100 percent); Ky Rev Stat Ann § 218A.435 (Michie 1995) (10 percent is distributed to the Justice Cabinet for various drug enforcement purposes and 36 percent to the Department of Corrections, but for forfeited coin or currency, 90 percent of 
also profitable for the Department of Justice, which receives a 20

the first $\$ 50,000$ and 45 percent of any excess goes to the participating law enforcement agency.); La Rev Stat Ann § 32:1550(k)(1) (West 1989) (60 percent goes to law enforcement, and 40 percent to the criminal courts.); 15 Me Rev Stat Ann \& 5821 (Supp 1996) (Describes what is forfeited, but has no disbursement provision.); Md Crimes and Punishments Code Ann $\$ \S$ 297(f), 297(k)(3)(v) (1996) (100 percent); Mass Ann Laws ch 94C, $\S 47$ (d) (Michie/Law Co-op 1995) (50 percent is distributed to prosecutors and 50 percent to the police, but only since 1984.); Mich Comp Laws Ann \& 333.7524 (West 1997) (100 percent); Minn Stat Ann $\$ 609.5315$ (5) (West Supp 1997) (70 percent is distributed to the seizing agency and 20 percent to the prosecuting agency.); Miss Code $\S$ 41-29-181(2) (Supp 1997) (80 percent goes to the initiating law enforcement agency and 20 percent is divided among the other participating agencies if any.); Mo Const, Art IX, \& 7; Mo Ann Stat $\S 513.623$ (Vernon Supp 1997) (Proceeds of all forfeitures distributed to the schools.); Mont Code Ann § 44-12-206 (1995) (100 percent is distributed to the participating agency, or if none, to the county in which the property was seized, for the sole purpose of drug enforcement.); Neb Rev Stat $\S \S 28-431(4), 28-1439.02$ (1995) (50 percent of cash forfeited is disbursed to the county drug law enforcement and education fund.); Nev Rev Stat $\S 179.1187$ (2) (1995) (100 percent, but proceeds must not be used to pay ordinary operating expenses.); NH Rev Stat Ann § 318-B:17-b(v)(a)(1) (Equity 1995) (45 percent of the first \$500,000); NJ Stat Ann § 2C:64-6(a) (West 1995) (95 percent is distributed based on contribution to seizure.); NM Stat Ann § 30-31-35(E), \& 22-8-32(A)(1) (Michie 1978 \& Supp 1992, 1997) (0 percent); 1997 NY Laws 1349(h)(i) (After costs and 40 percent distribution to the substance abuse service fund, 75 percent of remaining balance to participating law enforcement agency.); NC Const, Art IX, § 7; NC Gen Stat § 90-112(d)(1) (1993) (0 percent); ND Cent Code $\$ \S 19-03.1-36(5)(b), 54-12-14$ (1997) (100 percent, with amounts over $\$ 500,000$ distributed to a general fund.); Ohio Rev Code Ann $\$ \S 2933.43(D)(1)(c)$, 2925.43(B)(4)(c), 2925.44(B)(8)(c) (Baldwin 1992) (100 percent); 63 Okla Stat Ann $\S \S 2-$ 503(D)-(F), 2-506(L)(3) (West 1997) (100 percent, solely for enforcement of controlled dangerous substances laws.); Or Rev Stat Notes Preceding ORS $166.05 \$ \$ 10(1)(c)-11(b)(1)(b)$ (1995) (same); $42 \mathrm{~Pa}$ Cons Stat Ann $\S$ 6801(f)-(h) (Purdon Supp 1997) (Proceeds are equitably distributed between the district attorney and the attorney general for purposes of enforcing the Controlled Substance, Drug, Device and Cosmetic Act.); RI Gen Laws § 2128-5.04(b)(3)(A)(i) (Supp 1996) (After costs, 20 percent is distributed to the attorney general for drug-related law enforcement activities and 70 percent to state and local law enforcement divided proportionately by contribution to the investigation.); SC Code Ann $\S 44-53-530$ (e) (Supp 1996) (75 percent is distributed to law enforcement agencies and 20 percent to the prosecuting agency.); SD Cod Laws \& 34-20B-89(2) (1994) (100 percent of proceeds after costs go to the drug control fund.); Tenn Code Ann \$\$ 53-11-451(d)(4), 53$11-452(\mathrm{~h})(2)(\mathrm{A})$ (1991 \& Supp 1996) (100 percent of proceeds go to the drug enforcement program of the county in which the property was seized, except if real property, 50 percent goes to the participating agency and 10 percent to the special drug case investigation fund.); Tex Crim Pro Code Ann $\$$ 59.06(a)-(d), (h) Vernon Supp 1997) (Distribution is by local agreement between the state and law enforcement agencies.); Utah Code Ann $\$ 58-$ 37-13(8)(a) (1997) (Upon request, 100 percent will go to the seizing agency for the enforcement of controlled substance laws.); 18 Vt Stat Ann $\S$ 4244(d), 4247 (Equity Supp 1996) (Distribution is to the state treasurer for unspecified purposes.); Va Code $\$ 19.2$ 386.14(A-B) (1995) (90 percent is distributed based on contribution to seizure, and 10 percent to a state fund for law enforcement.); Wash Rev Code Ann $\$ \S 7.43 .100,43.10 .270$, 69.50.505(f)(i) (West 1992 \& Supp 1997) (Upon application, distribution is to law enforcement agency for enforcement of controlled substances law.); W Va Code $\S 60 \mathrm{~A}-4-403 \mathrm{a}(\mathrm{g})$ (1992) (Distribution is not specified.); Wis Stat Ann § 961.55(5)(b) (West Supp 1997) (Up to 50 percent is distributed for expenses of forfeiture and sale, balance to the school fund.); Wyo Stat $\S 35-7-1049(e)-(j)$ (Supp 1996) (Distribution is at the discretion of the commissioner.). 
percent share of assets with little if any expenditure of federal investigative or law enforcement resources. ${ }^{67}$ Indeed, the Department of Justice promotes federalization by providing larger shares to the state or local agency if it "could have forfeited the asset(s) on its own," but agreed to federal adoption instead. ${ }^{68}$ The profit and ease of federal adoption has led to widespread circumvention of stricter state forfeiture laws. ${ }^{69}$

${ }^{67}$ Federal adoptions may occur after seizure of the property or arrest. The local agency has thirty days after seizure to request the United States Attorney to adopt it as a federal case. Directive 93-1, Memo from Cary H. Copeland (Jan 15, 1993), in DOJ Asset Forfeiture Manual at B-584.138-2 (cited in note 62). Alternatively, local police may federalize a seizure by requesting the DEA, FBI, Immigration and Naturalization Service, Internal Revenue Service, Postal Inspection Service, or Bureau of Alcohol, Tobacco, and Firearms to assist in the investigation, seizure, or arrest. Directive 91-4, A Guide to Equitable Sharing of Federally Forfeited Property for State and Local Law Enforcement Agencies (Dec 1990 ), in DOJ Asset Forfeiture Manual at B-584.35-36 (cited in note 62).

According to Directive 93-1, in DOJ Asset Forfeiture Manual at B-584.138-71 (cited in note 62), forfeiture cases should generally be brought in the jurisdiction where the criminal defendants (if any) are being prosecuted. But massive numbers of forfeitures are being brought federally, either because an otherwise "local" case is handed to the Justice Department for federal prosecution, or because criminal prosecution is dispensed with.

68

In determining the amount of the equitable transfer for each participating agency, the following factors shall be considered: (1) whether the seizure was adopted or was the result of a joint investigation... (7) whether the state or local agency could have achieved forfeiture under state law, with favorable consideration given to an agency which could have forfeited the asset(s) on its own but joined forces with the United States to make a more effective investigation.

Directive 90-5, Equitable Sharing, in DOJ Asset Forfeiture Manual at B-553 (cited in note 62). The Department of Justice itself developed the equitable sharing concept. Directive 91-7, Equitable Sharing Information (May 1991), in DOJ Asset Forfeiture Manual at B$584.73,81$ (cited in note 62).

The Department of Justice also prohibits discontinuation of a federal forfeiture proceeding in favor of a state proceeding unless the U.S. Attorney personally approves it after considering the financial consequences to its Assets Forfeiture Fund. Directive 90-5, in DOJ Asset Forfeiture Manual at B-567 (cited in note 62).

${ }^{\infty}$ According to the Deputy Attorney General for the State of California, “[T] for the distribution of proceeds to law enforcement is a determining factor in motivating forfeiture-focused investigations and in choosing the forum for conducting forfeiture proceedings." Gary Schons, Fighting Drugs with Drug Money, Dicta: The Lawyer's Magazine 7, 40 (Dec 1988). Journalist Dan Baum has described the impact of this forum shopping in California as follows:

California ... allowed 65 percent of assets seized in state or local drug busts to be paid to the participating police, with the rest going for mental health, district attorneys, and informants. But the lawmen of the Golden Bear State still preferred to go federal. They perfected the art of presenting 100 percent complete cases to the U.S. attorney for "adoption," paying the U.S. Justice Department a 10 percent processing fee and keeping a full $\mathbf{9 0}$ percent of the seized assets. "That is, we receive a case which is in every respect a local case . . . and we put our cover on it," U.S. [A]ttorney Joseph Whitely told Congress. ... When Congressman Larry Smith suggested the scheme was making the federal government a partner-in "subverting" California 
The forfeiture laws were designed to combat drug crime by attacking the economic viability of drug trafficking enterprises, and they continue to be billed as the weapon of choice in the Drug War. The Director of the Department of Justice's forfeiture unit testified to a congressional subcommittee that "[a]sset forfeiture can be to modern law enforcement what air power is to modern warfare. ${ }^{m 70} \mathrm{But}$ in fact the aggressive use of forfeiture laws in the last decade has never produced this intended benefit. The $\$ 730$ million in 1994 federal forfeitures was surely inadequate to stifle a $\$ 50$ billion drug trade, although it was more than enough to reward police and government officials for their efforts. ${ }^{71}$

What forfeiture does do well is raise money. ${ }^{72}$ Police and prosecutors argue that 21 USC \& 881 enables them to carry out ordinary law enforcement business and raise money at the same time-to do well by doing good. ${ }^{73}$ Unfortunately, the real impact

laws, Whitely could only agree.

Baum, Smoke and Mirrors at 242 (cited in note 18). See also In Matter of Bly, 456 NW2d 195, 200 (Iowa 1990) (holding that Iowa's homestead statute prevented the forfeiture of Bly's home under the Iowa forfeiture statute); United States v One Parcel of Property Located at 1606 Butterfield Road, 786 F Supp 1497, 1503-04 (N D Iowa 1991) (allowing local authorities to circumvent the Iowa Supreme Court's ruling above by having the forfeiture "adopted" and proceeding under federal forfeiture laws); J. Bradley Horn, Note, The Reach of Iowa's Civil Forfeiture Statute: How Far Is Too Far?, 42 Drake L Rev 661, 673-74 (1993) (analyzing the Bly case); United States $v$ Winston-Salem/Forsyth County Board of Education, 902 F2d 267, 271-73 (4th Cir 1990) (upholding local police retention of federal equitable sharing proceeds over a challenge by a county board of education that it was entitled to such proceeds under North Carolina forfeiture laws). Congressional efforts to amend the forfeiture law to prevent such circumventions have failed, as detailed at text accompanying notes 276-79.

${ }^{70}$ Heilbroner, NY Times $\S 6$ at 70 (cited in note 47), quoting the 1992 testimony of Cary H. Copeland, then-Director of the Justice Department's Executive Office for Asset Forfeiture. See also United States $v$ Two Tracts of Real Property, 998 F2d 204, 213 (4th Cir 1993) ("One of the most potent weapons in the government's war on drugs is its ability to obtain the civil forfeiture of property that aids violations of the drug laws.").

"See Heilbroner, NY Times \$ 6 at 70 (cited in note 47).

72 This provides the alternative rationale, endorsed by the Supreme Court, that forfeitures can buy law enforcement strategies that are effective. According to the Court, the government's legitimate interest in forfeiture includes the funding it provides for law enforcement operations. Caplin \& Drysdale, Chartered v United States, 491 US 617, 629 (1989) ("[T]he Government has a pecuniary interest in forfeiture that goes beyond merely separating a criminal from his ill-gotten gains ... The sums of money ... are substantial, and the Government's interest in using the profits of crime to fund these law enforcement] activities should not be discounted.") (citation omitted). Only Justice Blackmun questioned whether pecuniary motive was an appropriate goal of the forfeiture statute in light of its legislative history. Id at 640 (Blackmun dissenting). See also Calero-Toledo, 416 US at 687 n 26 ("Seizure and forfeiture statutes also help compensate the Government for its enforcement efforts ....").

${ }^{73}$ See Alison Roberts Solomon, Comment, Drugs and Money: How Successful is the Seizure and Forfeiture Program at Raising Revenue and Distributing Proceeds?, 42 Emory 
of forfeiture has not been so benign. In practice, forfeiture laws have not simply enhanced the ability of law enforcement to do its job, but rather have changed the nature of the job itself. ${ }^{74}$ Both the crime prevention and due process goals of our criminal justice system are compromised when salaries, continued tenure, equipment, modernization, and departmental budgets depend on how much money can be generated by forfeitures.

\section{THE CONFLICT OF INTEREST OBJECTIONS TO SELF-FINANCING POLICE AGENCIES}

The most intuitively obvious problem presented by the forfeiture and equitable sharing laws is the conflict of interest created when law enforcement agencies are authorized to keep the assets they seize. It takes no special sophistication to recognize that this incentive constitutes a compelling invitation to police departments to stray from legitimate law enforcement goals in order to maximize funding for their operations. For example, as detailed below, some police departments now prefer to arrest drug buyers rather than dealers because buyers are sure to have seizable cash with them. Although profitable to the agencies involved, this agenda greatly undermines crime control because arresting buyers rather than sellers does little to reduce the supply of drugs in a community. It also results in the less culpable suffering more severe treatment, the antithesis of a just system based on proportional punishment. These destructive priorities are characteristic of the pervasive distortion of law enforcement policy that flows from targeting assets rather than crime. In Section II.B, we argue that no rational crime control program is possible until Congress repeals the conflict of interest license it has issued to police and prosecutors. First, however, we consider whether this conflict rises to a constitutionally objectionable level that might be remedied through litigation.

L J 1149, 1161-65 (1993) (critiquing the role pecuniary interest plays in motivating federal forfeiture law).

"A Justice Department evaluation noted the potential diversion of law enforcement policy when it warned that "it is important . . . that task force commanders use [their expertise in locating assets] for the benefit of the community effort to control drugs." JRSA, Five-Year Review at 23 (cited in note 1). 


\section{A. The Due Process Objection}

Impartiality is inseparable from justice. ${ }^{75}$ This principle is embedded in the constitutional due process guarantee, which includes the right to an impartial tribunal in both civil and criminal cases. ${ }^{76}$ The Supreme Court has found this right abridged whenever a conflict of interest exists that would "offer a possible temptation to the average man as a judge ... not to hold the balance nice, clear and true" between the parties. ${ }^{77}$

Such a conflict obviously exists when the factfinder has a personal pecuniary interest in the outcome, as when his compensation is contingent on conviction ${ }^{78}$ or the issuance of a search

${ }^{25}$ The requirement of impartiality is one aspect of the requirement that just decisions not be based on arbitrary, nonrelevant factors, such as the identity of the person affected or of the decisionmaker. We aspire to a "government of laws, not men." Elsewhere one of the authors has argued more generally that a distinguishing characteristic of any moral judgment is its universality, and therefore all those who forsake this requirement, whether for reasons of corruption or relativist ideology, abandon the tools with which to make moral decisions. See Eric Blumenson, Mapping the Limits of Skepticism in Law and Morals, 74 Tex L Rev 523, 531-34 (1996). In recent years, however, scholars have questioned this view on a variety of grounds-for example, that impartiality is unattainable; that morality must spring from an ethic of caring or identification rather than neutrality; or that we would do better to recognize the plurality and positionality of all judges and all judgments. See, for example, Margaret Jane Radin, The Pragmatist and the Feminist, in Michael Brint and William Weaver, eds, Pragmatism in Law and Society 127, 134 (Westview 1991); Gerald B. Wetlaufer, Rhetoric and its Denial, 76 Va L Rev 1545, 1568-69 (1990); Richard Rorty, Contingency, Irony and Solidarity 58-59 (Cambridge 1989); Patricia A. Cain, Good and Bad Bias: A Comment on Feminist Theory and Judging, $61 \mathrm{~S}$ Cal L Rev 1945 (1988).

${ }^{76}$ See Gibson $v$ Berryhill, 411 US 564, 579 (1973) (holding that "those with substantial pecuniary interest in legal proceedings should not adjudicate these disputes"); In re Murchison, 349 US 133, 136 (1955) (explaining that under the Due Process Clause, a judge cannot "be a judge in his own case ... [nor] try cases where he has an interest in the outcome"); Tumey $v$ Ohio, 273 US 510, 523, 532 (1927) (invalidating a conviction on due process grounds when criminal defendant was tried by a judge with a personal interest in convicting him). An impartial tribunal "safeguards the two central concerns of procedural due process, the prevention of unjustified or mistaken deprivations and the promotion of participation and dialogue by affected individuals in the decisionmaking process .... [T] preserves both the appearance and reality of fairness, 'generating the feeling, so important to a popular government, that justice has been done." Marshall v Jerrico, Inc, 446 US 238, 242 (1980), quoting Joint Anti-Fascist Committee v McGrath, 341 US 123, 172 (1951) (Frankfurter concurring).

${ }^{77}$ Tumey, 273 US at 532. See also Bracy v Gramley, 117 S Ct 1793, 1797 (1997) (“... the Due Process Clause clearly requires a 'fair trial in a fair tribunal' . . . before a judge with no actual bias against the defendant or interest in the outcome ....") (citation omitted); Hortonville Joint School District No 1 v Hortonville Education Assocation, 426 US 482, 493-97 (1976) (finding insufficient "stake" to constitute conflict); Pepsico Inc v McMillen, 764 F2d 458, 460 (7th $C i r$ 1985) (requiring recusal where counsel in case had considered employing judge); State $v$ Chinn, $146 \mathrm{~W}$ Va 610, 121 SE2d 610, 612 (1961) (due process abridged where fines paid judge's salary), and cases cited in notes 79 and 81.

${ }^{78}$ See Tumey, 273 US at 523. In Tumey, the mayor served as municipal judge in pos- 
warrant. ${ }^{79}$ But the Fourteenth Amendment Due Process Clause also may disqualify a judge who would receive no direct benefit from the ruling, as long as his department or agency would. Thus, in both Tumey $v$ Ohio $^{80}$ and Ward $v$ Village of Monroeville, ${ }^{81}$ the Supreme Court held it unconstitutional for a sitting mayor to preside as a judge and assess fines to be paid to the village treasury, because his responsibility for town finances gave him a motive to convict and jeopardized his impartiality. ${ }^{82}$ The precise criterion is a possible temptation: even a relatively small emolument may suffice, ${ }^{83}$ and the temptation need not have actually influenced the decision at all. ${ }^{84}$

session of liquor cases, and was paid expenses from the fines he collected. Id at 520. Tumey was convicted and fined $\$ 100$, a judgment that the Supreme Court found in violation of the Fourteenth Amendment because the mayor's decision might have been clouded by two conflicts of interest. First, the mayor had "a direct, personal, substantial, pecuniary interest in reaching a conclusion against him in his case" because he was paid an emolument contingent on the fines he collected ( $\$ 12$ in this case). Id at 523. Second, the mayor's role combined inconsistent positions as judge and financial administrator, the latter giving him a professional interest and motive to convict in order to enhance his town's budget. This "necessarily involves a lack of due process of law ...." Id at 534 .

${ }^{7}$ See Connally $v$ Georgia, 429 US 245, 250-51 (1977). Similarly, due process is abridged when the factfinder is empowered to rule on the professional license of a competitor. See Gibson, 411 US at 579 (holding the due process impartiality requirement violated when an administrative adjudicatory board of private optometrists adjudicated charges brought against a competitor).

273 US 510, 533-35 (1927).

${ }^{81} 409$ US 57, 59-62 (1972).

${ }^{82}$ In Ward, the mayor impermissibly occupied two inconsistent positions as judge and administrator, the latter giving him a partisan motive to convict in order to enhance the town budget, which necessarily abridged the due process guarantee. Id at 58-62. The Court noted that "[t]he fact that the mayor [in Kumey] shared directly in the fees and costs did not define the limits of the principle. ... Plainly [a] 'possible temptation' may also exist when the mayor's executive responsibilities for village finances may make him partisan to maintain the high level of contribution from the mayor's court." Id at 60.

* In Tumey, the Court discussed what degree or nature of interest would disqualify a judge. It reviewed English common law to demonstrate that "the slightest pecuniary interest of any officer, judicial or quasi-judicial, in the resolving of the subject matter which he was to decide, rendered the decision voidable.” 273 US at 524. Although the Court did not go so far, it enunciated the rule that any interest that would "offer a possible temptation to the average man as a judge to forget the burden of proof required to convict the defendant" or otherwise fail to "hold the balance nice, clear and true" requires disqualification. Id at 532. Only an interest that is so "remote, trifling and insignificant that it may fairly be supposed to be incapable of affecting the judgment" of an average man may be disregarded. Id at 531, quoting Thomas M. Cooley, Constitutional Limitations 594 (Little, Brown 7th ed 1903).

${ }^{84}$ See Aetna Life Insurance Co $v$ Lavoie, 475 US 813, 823-25 (1986) (finding impermissible "possible temptation" from conflict where judge's decision increased value of class action suit that judge had filed); In re Murchison, 349 US at 136 (observing that because justice must satisfy the appearance of justice, even judges with no actual bias must sometimes be barred from trial); Tumey, 273 US at 532 ("There are doubtless mayors who would not allow ... [the receipt of] $\$ 12$ costs in each case to affect their judgment in it; but 
These precedents should outlaw such forfeiture statutes as Louisiana's, which authorizes the criminal court to issue a warrant for seizure of the property, order forfeiture, and then allocate 40 percent of the proceeds to its own criminal court fund..$^{85}$ But the more potentially significant question is whether police and prosecutorial decisions must also satisfy due process standards of impartiality, and on this issue the constitutional parameters are yet to be fully developed. At this point, the Supreme Court has indicated only that (1) the stringent impartiality standard it requires of adjudicatory officials does not apply to prosecuting officials, but (2) neither is the prosecutor free from all conflict of interest restrictions. Some due process limits on law enforcement rewards do exist, but where between these poles they may be found must still be delineated, and likely will be when litigants focus on the equitable sharing payback law.

What constitutional guidance exists is found primarily in Tumey and a subsequent case, Marshall $v$ Jerrico, Inc. ${ }^{86}$ In Tumey, the Court relied on the mayor's pecuniary stake in the fine as reason enough to reverse the conviction, apparently unperturbed by the other shares distributed to the prosecution and police. ${ }^{87}$ Without specifically addressing Ohio's statutory scheme, the Court allowed that "the legislature of a State may, and often ought to, stimulate prosecutions for crime by offering to those who shall initiate and carry on such prosecutions rewards for thus acting in the interest of the State and the people. ${ }^{88}$ But the Court did not directly confront whether some law enforcement incentives create an unconstitutional conflict of interest until half of a century later, in Jerrico.

Jerrico upheld a section of the Fair Labor Standards Act that allowed a division of the Labor Department to retain the civil

the requirement of due process of law in judicial procedure is not satisfied by the argument that men of the highest honor and the greatest self-sacrifice could carry it on without danger of injustice.").

${ }^{85}$ See La Rev Stat Ann $\S 32: 1550(\mathrm{~K})$-(L) (40 percent of proceeds from sale of forfeited contraband allocated to court); $\$ 32: 1550$ (B) (issuance of warrants for search or seizure of forfeitable property); $\S 32: 1550(\mathrm{C})(4)$ (stating that when the defendant is acquitted, a rebuttable presumption against forfeitability applies unless the court finds a compelling reason for the forfeiture).

${ }^{86} 446$ US 238 (1980).

${ }^{87}$ The Ohio statute at issue allocated 15 percent of the fines collected to deputy marshals as compensation for securing evidence in liquor cases, 10 percent to the prosecuting attorney, 15 percent to the police officers, and the amount of costs to the mayor/hearing officer. Tumey, 273 US at 518-19.

${ }^{88}$ Id at 535. According to the Court, a legislature may also offer rewards or a percentage of the recovery to informers. Id at 534-35. 
penalties it assessed for child labor violations as compensation for the costs of determining violations and assessing penalties. ${ }^{89} \mathrm{Jer}-$ rico, Inc was fined $\$ 18,500$ by the Regional Administrator, appealed and lost before an administrative law judge, and then sued in federal district court on grounds that the reimbursement provisions violated its due process rights by encouraging agency personnel to seek and impose excessive fines. The district court granted Jerrico summary judgment, holding that this arrangement created an impermissible risk of bias and noting that:

The more appropriate procedure is simple and constitutionally sound: pay all civil money penalty funds directly into the Treasury of the United States. To allow only the Department of Labor to deviate from such a clear procedural alternative, to the detriment of alleged violators, would be to disregard the fundamental tenets of our legal system..$^{90}$

However, the Supreme Court rejected Jerrico's claims, finding the Tumey rule inapposite because department officials were performing purely prosecutorial functions. ${ }^{91}$ Distinguishing the conflict of interest prohibitions governing a factfinder, who must be and appear impartial, from the less stringent limitations on law enforcement officials, the Court held that prosecutors "need not be entirely 'neutral and detached'. In an adversary system, they are necessarily permitted to be zealous in their enforcement of the law. ${ }^{.92}$ But this was far from a blank check for prosecutorial self-aggrandizement, because the Court simultaneously emphasized that prosecutors are bound by at least some due process limitations on conflicts of interest:

We do not suggest . . . that the Due Process Clause imposes no limits on the partisanship of administrative prosecutors. Prosecutors are also public officials; they too must serve the public interest. In appropriate circumstances the Court has made clear that traditions of prosecutorial discretion do not immunize from judicial scrutiny cases in which the enforcement decisions of an administrator were motivated by im-

846 US at 242-52. See The Fair Labor Standards Act of 1938, Act of June 25, 1938, 52 Stat 1069, codified at 29 USC § 216(e) (1994).

so Jerrico, Inc $v$ United States Department of Labor, 86 Labor Cases (CCH) II 33,775, 48,679 (D DC 1979).

${ }^{91}$ Jerrico, 446 US at 247-48 (stating that the requirements of Tumey and Ward, designed for officials in a judicial or quasi-judicial capacity, are not applicable to prosecutors, and noting the wide discretion given to prosecutorial decisions).

${ }^{92}$ Id at 248 (citations omitted). 
proper factors or were otherwise contrary to law. Moreover, the decision to enforce-or not to enforce-may itself result in significant burdens on a defendant or a statutory beneficiary, even if he is ultimately vindicated in an adjudication. A scheme injecting a personal interest, financial or otherwise, into the enforcement process may bring irrelevant or impermissible factors into the prosecutorial decision and in some contexts raise serious constitutional questions. ${ }^{93}$

In Jerrico, the Court found that the constitutional barrier had not been crossed because the statute conferred no personal gain on the Regional Administrator, and the institutional benefit to the prosecuting department (the Employment Standards Administration ("ESA")) was too small to play a role in decisions about whom to prosecute and how much to fine. ${ }^{94}$ Analyzing the relevant three-year period, the Court noted that the ESA was not financially affected by the relatively minimal penalties collected. The national office of the ESA allocated the penalties among the regional offices and other departments, and thus a regional office could not expect to enjoy the proceeds of any penalties it assessed. Finally, the Court found that because any penalties distributed to a regional office were determined in proportion to office expenses rather than the amount collected, a regional office would obtain no benefit by assessing an unjustifiably large penalty. ${ }^{95}$ Given this undisputed record, the Court found the claim that Section 16(e) would bias the decisions of the regional administrator "too remote and insubstantial to violate the constitutional constraints" on prosecutors. ${ }^{96}$ There is no implication here that the Justices would have tolerated a scheme that, for example, paid over traffic fines to the police officer who issued the citation. Rather, the Court examined three relevant factors-the de-

${ }^{93}$ Id at 249-50 (citations omitted). Among the cases cited was Bordenkircher $v$ Hayes, 434 US 357 (1978), the relevance of which is further discussed in note 126. See also Young $v$ United States, 481 US 787, 807 (1987) ("The requirement of a disinterested prosecutor is consistent with our recognition that prosecutors may not necessarily be held to as stringent a standard of disinterest as judges.").

94 Jerrico, 446 US at 250-52. "Unlike in Ward and Tumey, it is plain that the enforcing agent is in no sense financially dependent on the maintenance of a high level of penalties." Id at 251.

${ }^{\circ}$ Id at 245-46, 250-51.

\% Id at 243. However, this conclusion can be challenged factually. Nothing in the Court's statement of facts excludes the real possibility that the ESA's national office might require its regional administrators to seek higher fines because of the potential financial benefit it could receive in this or future years, regardless of how a particular regional office might fare. 
gree of institutional financial dependence on the prosecutorial decision, the official's personal stake, and the penalty distribution formula - and found that none of them suggested any temptation toward impropriety. ${ }^{97}$

Before applying the Jerrico criteria to the forfeiture laws, we should note that the Court's sharp distinction between judicial and prosecutorial standards is controversial and belies the overwhelmingly dispositive role of discretionary prosecutorial decisions in a system where few cases ever go to trial: in most cases, the integrity of the system depends primarily on the fairness of the law enforcement branch. The Court would have done better to hold that due process requires law enforcement agencies to remain untarnished by any actual or perceived temptation toward self-aggrandizement. ${ }^{98}$ Instead of a bright line rule, however, Supreme Court doctrine after Tumey and Jerrico construes the constitutional limitation as a matter of degree, permitting those incentives that "stimulate" law enforcement officials to do their job without distorting or biasing them toward unjust prosecutions or excessive penalties. ${ }^{99}$ Whether a prosecutorial payback provision violates the Fourteenth Amendment thus necessarily requires a factual inquiry into the effect of the particular rewards on the agency. To assess the constitutionality of equitable sharing, we must take a much closer look at its operation in practice.

What is remarkable about the three empirical factors that led the Jerrico Court to uphold the child labor prosecution is that in the case of forfeiture, every one cuts the other way, and to an extreme degree. One could hardly design an incentive system better calculated to bias law enforcement decisions than the present forfeiture laws. We now consider the Jerrico factors in order.

Financial dependence: The ESA division of the Labor Department obtained no financial benefit from the penalties it assessed: the penalties collected totaled less than 1 percent of the ESA's budget, and, because more than this amount was returned to the Treasury, the penalties had not increased the ESA's funding at all. By contrast, numerous law enforcement agencies now

${ }^{97}$ Id at 250-51.

${ }^{98}$ As the opinion noted, "justice must satisfy the appearance of justice." Id at 243 , citing Offutt $v$ United States, 348 US 11, 14 (1954).

${ }_{99}$ One potential effect of an incentive system is a selective prosecution policy in which those whose prosecution would most enhance the government's coffers are targeted. The Court noted this issue but found it unnecessary on the facts to decide "whether different considerations might be held to apply if the alleged biasing influence contributed to prosecutions against particular persons, rather than to a general zealousness in the enforcement process." Jerrico, 446 US at $250 \mathrm{n} 12$. 
rely on forfeitures to fund a significant part of their operations. The gross amounts are prodigious: by 1987, the Drug Enforcement Administration ("DEA") was effectively paying for itself, with seizures exceeding its annual budget. ${ }^{100}$ Between 1985 and 1991 , the Justice Department collected more than $\$ 1.5$ billion in illegal assets. ${ }^{101}$ Over the next five years, the Justice Department almost doubled this intake, depositing $\$ 2.7$ billion in its Asset Forfeiture Fund. ${ }^{102}$ This forfeiture income sometimes is required to operate the Department, which has regularly exhorted its attorneys to make "every effort" to increase "forfeiture production" so as to avoid budget shortfalls. ${ }^{103}$

${ }^{100}$ Gary Shons, Asset Forfeiture in California: A Preview of $A B$ 4162, Prosecutor's Brief 5 (Fall 1988). That year the DEA seized $\$ 505$ million in Section 881 forfeitures.

${ }^{101}$ Seizure Nets $\$ 1.5$ Billion, USLW (cited in note 61 ). “\$460 million . . . [was] deposited into the fund in 1990, which was a 28 percent increase over fiscal 1989 and 15 times greater than the total in 1985, when the fund was established." Id. The total value of forfeited cash and property thus represents a growth in asset forfeitures of over 1,500 percent since 1985. See also Department of Justice, Federal Forfeiture of the Instruments and Proceeds of Crime: The Program in a Nutshell 1 (1990).

${ }^{102}$ Walsh, Wash Post at F7 (cited in note 65). The article reports that the federal government has received the following amounts from asset forfeitures in criminal cases: 1986: $\$ 93.7$ million; 1987: \$177.6 million; 1988 : $\$ 205.9$ million; 1989 : $\$ 580.8$ million; 1990 : $\$ 459.6$ million; 1991: \$643.6 million; 1992: \$531.0 million; 1993: \$555.7 million; 1994: $\$ 549.9$ million. These figures include nondrug-related forfeited assets, particularly from insider trading cases. Id. During the period of major growth, 1985 through 1990 , asset seizures increased at an average annual rate of 59 percent, with the Asset Forfeiture Fund inventory quadrupling to $\$ 1.3$ billion. Smith, Forfeiture I 1.02 at 1-23 to 1-24 (cited in note 44), citing Annual Report of the Department of Justice Asset Forfeiture Program 5 (DOJ 1990).

Reports on some U.S. Attorneys' offices show seizures equal to much or all of their operating budgets. See, for example, Ruth Hawk, Western District Office Pays for Itself and More, Pa L J 7 (Nov 8, 1993) (According to U.S. Attorney Frederick W. Thieman, "The 1993 figures demonstrate that [debt collection and $\$ 1.9$ million in asset forfeitures] routinely pay for the operation of the entire U.S. Attorney's Office [of the Western District of Pennsylvania] ... . He noted that the combined total-more than $\$ 10$ million-exceeded the entire operating budget of his office by about 75 percent."); Pratt and Petersen, 65 St John's $L$ Rev at 671 (cited in note 27) ("In an eight month period during 1989, for example, the United States Attorney's office in the Eastern District of New York collected $\$ 37,000,000$ from civil forfeitures," four times its operating budget), citing NY L J 1, 21 (July 27, 1989).

${ }^{103}$ In 1990, the Attorney General urged U.S. Attorneys to increase the volume of forfeitures in order to meet the annual budget target. "Failure to achieve the $\$ 470$ million projection would expose the Department's forfeiture program to criticism and undermine confidence in our budget projections. Every effort must be made to increase forfeiture income during the remaining three months of [fiscal year] 1990." United States $v$ James Daniel Good Real Property, 510 US 43, 56 n 2 (1993), quoting Executive Office for United States Attorneys, 38 United States Attorney's Bulletin 180 (DOJ 1990). Consider also a 1989 memorandum from Acting Deputy Attorney General Edward S.G. Dennis, Jr., which urged U.S. Attorneys to make forfeiture proceedings a priority: "It is imperative that we fulfill the commitment that was made to increase forfeiture production." Directive 89-1, Processing of Pending Forfeiture Cases 1 (June 21, 1989), in DOJ Asset Forfeiture Manual 
Similar concerns motivate state and local officials. A 1991 Justice Department memorandum observed that state and local law enforcement agencies were becoming increasingly dependent upon equitable sharing of forfeiture proceeds. ${ }^{104}$ (As of 1994 the Department had transferred almost $\$ 1.4$ billion in forfeited assets to these agencies. ${ }^{105}$ ) Similarly, a study of multijurisdictional drug task forces participating in the Byrne grant program found that these task forces had seized over $\$ 1$ billion in assets between 1988 and $1992,{ }^{106}$ and that many of their commanders "expect to have to rely increasingly on asset forfeitures for future resources. ${ }^{\text {p107 }}$

Personal interest: The Jerrico Court also stressed the degree of the prosecutor's "personal interest, financial or otherwise" in the matter. ${ }^{108}$ Although the Justices found that the ESA Regional

at B-481 (cited in note 62). See also Directive 91-6, 1991 Memorandum from Principal Associate Deputy Attorney General George J. Terwilliger, III, to all U.S. Attorneys, Need for Increased Emphasis upon Criminal Forfeitures (Apr 22, 1991), in DOJ Asset Forfeiture Manual at B-584.71 (cited in note 62) (directing U.S. Attorneys to "exert strong management direction" by ensuring "that your criminal prosecutors are aggressively focussing [sic] not only upon the conviction of individuals but also upon the civil or criminal forfeiture of their assets . . .."); Directive 91-12, Memorandum from Director of the Executive Office for Asset Forfeiture, Cary H. Copeland to all U.S. Attorneys, Need to Expedite Asset Forfeiture Deposits (July 8, 1991), in DOJ Asset Forfeiture Manual at B-584.138-13 (cited in note 62) ("Funding of initiatives important to your components will be in jeopardy if we fail to reach the projected level of forfeiture deposits. . . . Please advise your staff of specific actions that can be taken to maximize deposits to the [Asset Forfeiture] Fund between now and the end of the fiscal year."); Memorandum from Attorney General Janet Reno, FBI Director Louis J. Freeh, and DEA Administrator Thomas Constantine, Asset Forfeiture Program Activity 1-2 (Feb 12, 1996) ('We are requesting that each United States Attorney . . . develop ways to make the fullest, appropriate use of the forfeiture statutes .... Forfeiture specialists should be involved early and consulted frequently during the investigations and prosecution of criminal cases, including settlement and plea discussions.").

${ }^{106}$ See Directive 91-14, Memorandum from Director and Chief Counsel of the Executive Office of Asset Forfeiture Cary H. Copeland, Expediting Delivery of Equitable Sharing Transfers 1 (Oct 1, 1991), in DOJ Asset Forfeiture Manual at B-584.138-23 (cited in note 62) (noting that "states and local agencies are increasingly dependent upon sharing proceeds").

${ }^{106}$ Janet Reno, Foreword, A Guide to Equitable Sharing of Federally Forfeited Property for State and Local Law Enforcement Agencies (DOJ 1994).

${ }^{105}$ JRSA, Five-Year Review at 10 (cited in note 1). In 1991, the peak year during the five-year study, multijurisdictional drug task forces seized assets worth more than $\$ 346$ million, a 147 percent increase over 1988 seizures. Id at 9 . These amounts include only those seizures by task forces receiving federal Byrne grants. They do not include assets seized by DEA task forces or other task forces, or seizures under state forfeiture laws. Id at 2,9 .

${ }^{107}$ Id at 23 . The report provides figures showing an 89 percent increase in asset seizures by task forces between 1988 and 1992, noting that such seizures "provide resources to task forces that have experienced decreased funding." Id at 9.

${ }^{103} 446$ US at 249. 
Administrators had no personal stake in the penalties they assessed, they did note that constitutional violations might have arisen had the arrangement injected a personal stake into the prosecutor's decisions. ${ }^{109}$ The revised forfeiture laws have now produced such a case: when a police department relies on a steady stream of forfeiture income to pay for its operations, as many now do, an officer's choice of who and what to target may mean the difference between a paycheck and a pink slip. ${ }^{110}$ Anyone who doubts whether job maintenance qualifies as a personal stake should read the sociologist Northcote Parkinson's witty study on the subject. ${ }^{111}$ There are carrots as well, including more generous working conditions or the use of seized assets from baseball gloves to automobiles. ${ }^{12}$ Some police departments base evaluations in part on the officer's success in asset seizures, ${ }^{113}$ and at least one city ordinance actually gives individual officers a personal share of the forfeiture take. ${ }^{114}$

The funding formula: Finally, in Jerrico the Court stressed that the statutory scheme reimbursed regional offices according to their expenses rather than their collections, providing no rea-

\footnotetext{
${ }^{100}$ Id at 249-50.

${ }^{110}$ Indeed, in some departments, police salaries are paid directly from asset forfeiture funds, so long as the funds supplement rather than supplant budgeted positions. Directive 91-4 at 8, in DOJ Asset Forfeiture Manual at B-584.35-36 (cited in note 67).

"11 C. Northcote Parkinson, Parkinson's Law (Houghton Mifflin 1957). One of Parkinson's laws is that officials seek to make work for each other, even when there is nothing to do. Id at 4. As illustrations, he points to the British Colonial Office, which expanded exponentially as the British Empire was declining, and British Admiralty officials, who succeeded in almost doubling their number as ships in commission declined by two-thirds. Id at 8-11. "The officials would have multiplied at the same rate had there been no actual seamen at all, ${ }^{\text {Parkinson concludes. Id at } 10 .}$

${ }^{112}$ See, for example, Russell Carolo and Doreen Marchionni, Seizure Laws Have Been Wheels of Fortune for Tacoma Police, [Tacoma] News Trib A1 (June 20, 1994) (reporting that the Tacoma Police Department had acquired and retained more than fifty vehicles through forfeiture); Russell Carolo and Doreen Marchionni, Above the Law: Seized or Stolen, [Tacoma] News Trib A1 (June 19, 1994) (reporting seizure and use of microwave ovens, baseball gloves, televisions, and automobiles).

${ }^{13}$ See J. Mitchell Miller and Lance H. Selva, Drug Enforcement's Double-Edged Sword: An Assessment of Asset Forfeiture Programs, 11 Justice Q 313, 319 (1992) (citing one such policy in Southern California, and quoting a drug enforcement agent there as saying, "my supervisor made it extremely clear that big money cases were a lot more favorable for your overall evaluation than big dope cases").

"See Cops in Utah City Will Get a Commission on Drug Busts, Associated Press (Jan 31, 1995), quoting Mayor Mike Dalpiaz, author of the Helper, Utah Forfeiture Incentive Resolution, as promising that "[I]f the city gets a house through a drug forfeiture, and we put it on the market and sell it for $\$ 50,000$, then by God the guy who made the bust is going to get a nice bonus check for his work ...." This ordinance raised community concerns about the risk of police planting drugs on people in order to seize their property. See also Brian McGrory, Only Cops Seem to Like Town's Plan to Offer Cut of Drug Forfeiture Funds, Phoenix Gaz A29 (Mar 3, 1995).
} 
son for regional offices to seek unreasonably large penalties. ${ }^{115}$ No such restraint exists in the asset retention statutes; the larger the seizure, the higher the reward for each participating office.

* * *

The three factors just discussed were dispositive in Jerrico because they were strong indicia that prosecutors were unaffected by the ESA's negligible financial stake in their penalty assessments. In the forfeiture case the same factors point in the opposite direction, strongly tempting a law enforcement agency to tailor its decisions to enhance institutional funding. Have law enforcement decisions actually been influenced and corrupted by this temptation? To answer this question, we need not merely extrapolate from the Jerrico indicia, or invoke economic models, ${ }^{116}$ or rely on conjecture at all. We can instead directly examine the recent history of law enforcement activity. This record shows that the forfeiture-reward system has done far more than stimulate zealous enforcement: It has grossly distorted police and prosecutorial priorities, infecting virtually every phase of the criminal justice system. The consequence is an often counterproductive, sometimes pernicious law enforcement agenda.

At this point we focus only on those corrupted decisions that might be found to abridge the constitutional due process guarantee. We shall assume that this requires proof not only that the prosecution is contaminated by a significant conflict of interest, but also that the defendant or claimant suffers some legally cognizable prejudice as a result-for example, that she would not

${ }^{115}$ See 446 US at 251.

${ }^{116}$ For an economist, asset forfeitures are one type of "consumer good" purchased by law enforcement agencies, along with neighborhood patrols, homicide investigations, forensic tests, and all other law enforcement activities. The pricing of these various goods affects how much total enforcement the agency will buy, and how it allocates its purchases among alternative enforcement activities.

When Congress channeled most forfeited assets back to the agency that seized them, the cost of asset seizure fell substantially, producing both an "income effect" (lower prices effectively increased the budget of the law enforcement agency) and a "substitution effect" (asset seizure became a more attractive purchase for law enforcement relative to alternative purchases as its price declined). The income effect should ultimately result in a larger quantity of law enforcement purchases (including asset seizures and excluding only some "inferior goods" which are, like Spam, purchased only when more attractive alternatives are not affordable). The substitution effect, however, is our focus, because it predicts that the forfeiture laws should powerfully alter law enforcement priorities, increasing asset seizures at the expense of other law enforcement activities. See David M. Kreps, A Course in Microeconomic Theory 58-62 (Princeton 1990). On price elasticity generally, see William F. Samuelson and Steven G. Marks, Managerial Economics, 85-93 (Dryden Press 2d ed 1995). 
have been targeted, or treated as harshly, in the absence of the agency's financial interest. ${ }^{117}$

Consider first police investigations. The shift in law enforcement priorities, from crime control to funding raids, is perhaps best revealed by the advent of the "reverse sting," a now common police tactic that rarely was used before the law began channeling forfeited assets to those who seized them. ${ }^{118}$ The reverse sting is an apparently lawful version of police drug dealing in which police pose as dealers and sell drugs to an unwitting buyer. The chief attraction of the reverse sting is that it allows police to seize a buyer's cash rather than a seller's drugs (which have no legal value to the seizing agency). ${ }^{119}$ According to one reverse-sting participant, "This strategy was preferred by every agency and department with which I was associated because it allowed agents to gauge potential profit before investing a great deal of time and effort. [Reverse stings] occurred so regularly that the term reverse became synonymous with the word deal."120 Whether the suspects were engaged in major or trivial drug activity, and whether the strategy actually placed more drugs on the street, were of little, if any, importance. Even if a sting targeted a drug dealer, the police might defer the operation until the dealer sold some of the drugs to other buyers in order to make the seizure incident to arrest

\footnotetext{
${ }^{117}$ See text accompanying note 126.

${ }^{118}$ The most recent convert to this tactic is the New York Police Department, which inaugurated its first reverse sting effort in October 1997 with the arrest of seventy-two marijuana buyers in Washington Square Park. Mayor Giuliani announced that such reverse stings would henceforth be instituted throughout the city. Norimitsu Onishi, Mayor Unveils Sting Strategy Against Drugs, NY Times B1 (Oct 29, 1997).

${ }^{119}$ See Miller and Selva, 11 Justice $Q$ at 320 (cited in note 113). Reverse stings are also attractive to police officers because they can be executed with little investigation, while great expenditures of time and manpower are usually necessary when the targets are drug dealers. This is not to say that reverse stings are always illegitimate. In some cases, they may help shut down open air drug markets by deterring buyers, or apportion punishment to include the suburban buyers who enter and help "corrupt" some inner city neighborhoods. But in ordinary circumstances, arresting buyers rather than sellers targets the less culpable and less dangerous individuals while neglecting the more serious crimes, and involves the police in activity which may easily degenerate into a program of wholesale entrapment.

${ }^{120} \mathrm{Id}$ at 325. The participant, Mitchell Miller, worked as a police officer for one year while attending a graduate school program in sociology. He reports that the officers he worked with preferred arresting a buyer with a bankroll and a good car to a trafficker with a large quantity of drugs and no cash, and concludes that the forfeiture laws give law enforcement a powerful incentive to "allow the illegal drug market to continue. In this market, the drug enforcers and the drug traffickers become symbiotic beneficiaries of the 'War on Drugs." Id at 324, 333. See also Associated Press, State Finds Room for Improvement in Drug Team, Louisville Courier-J 1B (Sept 5, 1993), citing a state report on a Paducah, Kentucky multijurisdictional task force that criticized the task force for making reverse stings "standard operating procedure."
} 
more profitable. ${ }^{121}$ Alternatively, law enforcement agencies might select their targets according to the funding they could provide rather than the threat they posed to the community. A Department of Justice report proposed precisely this approach to multijurisdictional task force commanders, suggesting that as asset seizures become more important, "it will be useful for task force members to know the major sources of these assets and whether it is more efficient to target major dealers or numerous smaller ones." 122

A similar motivation may underlie the otherwise baffling policy adopted in 1986 by both the New York City and Washington, D.C. police departments. Invoking 21 USC $\S 881(\mathrm{a})(4)$, the policy directed police to seize the cash and cars of persons coming into the city to buy drugs. ${ }^{123}$ The consequence of this strategy was that the drugs that would have been purchased continued to circulate freely. Patrick Murphy, formerly the Police Commissioner of New York City, explained the origin of this policy to Congress. Police, he said, have

a financial incentive to impose roadblocks on the southbound lanes of I-95, which carry the cash to make drug buys, rather than the northbound lanes, which carry the drugs. After all, seized cash will end up forfeited to the police department, while seized drugs can only be destroyed. ${ }^{124}$

For prosecutors as well, funding exigencies have preempted other considerations. One Department of Justice manual governing racketeering prosecutions, for example, suggests that prosecution may be contingent on the presence of forfeitable assets, rather than forfeiture being an incident of prosecution. ${ }^{125}$ Consequently, prosecutors have become expert at discovering the presence and value of assets in cases under investigation, and checking for liens on such assets. The Supreme Court will eventually have to decide whether this is the kind of prosecutorial discretion that, in Jerrico's formulation, must not be immune from

${ }^{121}$ See Miller and Selva, 11 Justice $Q$ at 328 (cited in note 113).

${ }^{122}$ JRSA, Five-Year Review at 23 (cited in note 1).

${ }^{123} \mathrm{Smith}$, Forfeiture II 1.02 at 1-11 to 1-12 (cited in note 44 ).

${ }^{124}$ Richard Miniter, IIl Gotten Gains, 25 Reason 32, 34 (Aug/Sept 1993).

${ }^{125}$ See the Department of Justice manual concerning racketeering forfeitures, which notes that a "preliminary investigation to determine what property would be subject to forfeiture may be required simply in order to obtain Departmental authorization for a RICO or CCE prosecution." David B. Smith and Edward C. Weiner, Criminal Forfeitures Under the RICO and Continuing Criminal Enterprise Statutes 7 (DOJ 1980). 


\section{judicial scrutiny because "the enforcement decisions of an ad- ministrator were motivated by improper factors . . . ."}

${ }^{126}$ Jerrico, 446 US at 249. In the situations described above, prosecutorial discretion is influenced by two related, arguably improper factors: the assets of the potential defendant and, more directly, the prosecutor's financial stake in bringing the prosecution. Targeting suspects according to these factors may violate the due process right to an impartial prosecutor enunciated in Jerrico. But prosecutorial treatment based on the wealth of the defendant also implicates a different line of cases based on the equal protection guarantee. We take each constitutional claim in turn.

The due process right to an impartial prosecutor. There are three questions that a court must address in order to resolve a due process challenge to prosecutions motivated by the financial rewards available through forfeiture: (1) Is financial self-interest constitutionally barred from prosecutorial consideration? (2) Must a defendant selected on this basis show prejudice in order to obtain a remedy? (3) If so, what constitutes such prejudice?

On the first issue, Jerrico's reasoning makes clear that prosecutions selected according to the prospect of law enforcement enrichment may constitute an improper factor biasing the charging decision if they do not merely "stimulate officials to do their job" but bias them towards unjust prosecutions or excessive penalties. Jerrico, 446 US at 249-50. As the Supreme Court noted in its strong admonition in Berger $v$ United States, 295 US 78, 88 (1935), "The United States Attorney is the representative not of an ordinary party to a controversy, but of a sovereignty whose obligation to govern impartially is as compelling as its obligation to govern at all .... We note, however, that the Supreme Court has afforded prosecutors substantial deference in its charging decisions; for example, in Bordenkircher v Hayes, 434 US 357, 363-65 (1978), the Court upheld harsher prosecutorial treatment in response to the defendant's rejection of a plea bargain. Bordenkircher allowed prosecutors broad discretion, while noting that there are constitutional limits upon its exercise. Id at 364-65. While the plea bargaining tactics at issue did not cross these limits according to the Court, the same should not be said of prosecutions selected according to the financial advantages they offer the prosecuting attorney's office, which are tied neither to the defendant's culpability nor to any exigencies of the criminal justice system.

Second, must the defendant show he suffered prejudice from the corrupted decision? Suppose a defendant clearly establishes that the prosecutor stood to benefit financially from her conviction. If she would have been prosecuted anyway and suffered the same disposition, and if she is guilty of the charges, does her lack of prejudice preclude a due process claim based on this conflict? It would seem that the conflict must have played some role in prosecutorial decisionmaking in order to constitute an "impermissible factor" at all. Against this one might argue that not all "factors" are necessarily dispositive, so a defendant who would have been treated the same absent the conflict should still have a claim; or that the language from Jerrico, quoted above, conspicuously does not enunciate a requirement of prejudice; or that the bright line rule applied to some conflict situations should be applied here, because of the practical difficulties in tracking agency decisionmaking and acquiring proof that a potentially corrupting factor was actually considered.

Third, assuming a showing of prejudice is required, what constitutes sufficient prejudice? If a guilty defendant would not otherwise have been prosecuted or treated as harshly, this should be entirely sufficient to meet any prejudice requirement. Although the Bordenkircher opinion held that the prosecutor has broad discretion as to whom to prosecute, it did acknowledge that some factors are impermissible even where probable cause to indict exists. Id at 363, citing Oyler $v$ Boles, 368 US 448, 456 (1962). The Bordenkircher and Jerrico decisions clearly contemplate that certain arbitrary or vindictive prosecutorial decisions cannot be immunized by the fact that, absent the factor, the defendant could have been properly prosecuted. See Bordenkircher, 434 US at 363; Jerrico, 446 US at 249. Thus, any loss of even-handedness in prosecutorial treatment should be found to entail cognizable prejudice, whether in investigation, charging, plea bargaining, grant- 
Consider also forfeiture's corrupting influence on the disposition of criminal cases. Ironically, as the Drug War was escalating during the 1980s and 1990s, major efforts were underway to remove corrupt influences and unjust disparities from criminal sentences. The federal government and many states sought to accomplish this by rewriting their sentencing laws to specify the sentence that fit each crime and the criminal history of each of-

ing of immunity, challenging evidence at trial, or other exercise of discretionary power.

The equal protection right against selective prosecution. The right to equal protection of the laws, rooted in the Fifth and Fourteenth Amendments, provides a distinct challenge based not on the prosecutor's conflicting interests but on his selecting defendants according to their assets. Imagine a prosecutorial policy that mandates targeting only asset-rich defendants, or a policy (equally forfeiture-driven, but at a different stage of prosecution) targeting poor defendants by mandating more lenient plea bargains for those wealthy defendants who agree to forfeit their assets. Would such selective prosecutions violate the equal protection guarantee?

The equal protection right applies not merely to the laws as written but to their enforcement, Yick Wo $v$ Hopkins, 118 US 356, 373-74 (1886), and therefore provides a defense to selective prosecutions. But because prosecutors with scarce resources are necessarily selective in whom they prosecute, the salient question is whether the prosecutor strayed beyond constitutional bounds in exercising his discretion. Equal protection cases have required defendants to show that other equally culpable violators have not been prosecuted and that this disparate treatment was "deliberately based on an unjustifiable standard such as race, religion, or other arbitrary classification." Oyler, 368 US at 456. Where a prosecutor has selected targets according to their wealth and the resulting group does not constitute a "suspect class" entitled to strict scrutiny, a court will have to decide whether this classification is arbitrary or whether it "rationally furthers some legitimate, articulated state purpose and therefore does not constitute invidious discrimination ...." San Antonio Independent School District v Rodriguez, 411 US 1, 17, 26 (1973). See also Cleveland $v$ Cleburne Living Center, 473 US 432, 446 (1985) (finding that the retarded do not constitute a suspect class entitled to strict scrutiny, but must show that the classification is not "rationally related to a legitimate governmental purpose"). As the facts above show, a court would have more than sufficient grounds to rule that: (1) fund raising may not be the overriding objective of prosecutorial decisions about whom to prosecute, and (2) selection by wealth is not rationally related-and perhaps is inversely related-to other, clearly legitimate objectives of law enforcement, such as deterrence or retribution.

As with the due process challenge, any equal protection claimant confronts the judiciary's reluctance to review prosecutorial decisions, Wayte $v$ United States, 470 US 598, 60710 (1985), and must rebut a presumption that prosecutors have properly discharged their official duties. See United States v Armstrong, 116 S Ct 1480, 1486 (1996), citing United States $v$ Chemical Foundation, Inc, 272 US 1, 14-15 (1926). Some courts have nevertheless proven receptive to arguments that particular enforcement policies or decisions could not be related to a legitimate law enforcement purpose. See Esmail v Macrane, 53 F3d 176, 179 (7th $\mathrm{Cir}$ 1995) (holding that selective enforcement against an individual, where motivated by personal malice, may violate equal protection); Olshock $v$ Village of Skokie, 541 F2d 1254, 1260 (7th Cir 1976) (finding equal protection abridged when policemen were disciplined differently depending on whether they were represented by counsel); United States $v$ Robinson, 311 F Supp 1063, 1065-66 (W D Mo 1969) (finding the enforcement of a privacy statute against private detectives but not public officials is impermissibly arbitrary); People v Acme Markets, Inc, 37 NY2d 326, 372 NYS2d 590, 593-94 (1975) (finding equal protection abridged when Sunday closing laws were enforced based upon complaints that reflected private motives). 
fender. ${ }^{127}$ But these sentencing reform laws have been largely undone in the drug area. ${ }^{128}$ Forfeiture laws promote unfair, disparate sentences by providing an avenue for affluent drug "kingpins" to buy their freedom. This is one reason why state and federal prisons now confine large numbers of men and women who had relatively minor roles in drug distribution networks, but few of their bosses. ${ }^{129}$

${ }^{127}$ See, for example, The Sentencing Reform Act of 1984, Pub L No 98-473, 98 Stat 2017 , codified at 28 USC $\$ \S 991-98$ (1994). This law abolished parole and established a Sentencing Commission with the mandate of promulgating sentencing guidelines. The Sentencing Commission then removed the traditionally broad sentencing discretion from the trial judge, substituting a precise grid by which a determinate sentence is calculated. For example, the Guidelines provide particular points, corresponding to time to be served, for robberies committed with the use of a gun (plus six), § 2B3.1(b)(2)(B); with an express death threat (plus two), \& 2B3.1(b)(2)(F); that was designed to obtain a controlled substance (plus one), § 2B3.1(b)(5); and so on. These aggravating factors increase the base level of the robbery offense, and will increase the punishment. Roger W. Haines, Kevin Cole, and Jennifer C. Woll, eds, Federal Sentencing Guidelines Handbook 146-47 (Shepard's/McGraw Hill 1994).

${ }^{223}$ Drug cases are theoretically subject to assorted mandatory minimum sentences promulgated by the Anti-Drug Abuse Act of 1986, and by the parallel incarceration periods mandated by the Guidelines sentencing grid. However, if the prosecutor wishes to evade these sentences in service of an appealing plea bargain, he may obtain a much lower sentence in one of two ways. He may file a motion pursuant to 18 USC § 3553(e), allowing the court to reduce the sentence for a defendant who has provided "substantial assistance" in the prosecution of others; or he may tell the federal probation department that the defendant's crime involved a lesser quantity of drugs than was actually the case. The AntiDrug Abuse Act of 1986, Pub L No 98-473, 98 Stat 1989, codified at 18 \& USC 3553(e) (1994).

${ }^{129}$ According to Eric Sterling, Director of the Criminal Justice Policy Foundation, "only 11 percent of drug offenders in federal prison are high-level traffickers, while more than 50 percent are low-level." Derrick Z. Jackson, Our Fraudulent War on Drugs, Boston Globe A27 (Sept 13, 1996). First Circuit Chief Judge Juan Torruella has noted that in his experience, "penalties for drug trafficking are imposed on individuals other than those most culpable ... . The 'big fish,' if caught at all, are able to work out deals with the government which may leave them with light sentences or even without any prosecution. This result . . . is essentially an immoral outcome which tarnishes our entire judicial system." Torruella, 14 Yale J Reg at 256 (cited in note 60).

Relatively harsher penalties for the "mules" often result because they usually have neither forfeitable assets nor useful information to trade for prosecutorial leniency. There are other factors as well, however. For example, in the drug area passions run high enough to taint the sentencing laws themselves, not merely their application. One wellnoted example is the disparity between crack and cocaine mandatory sentences (100 to 1$)$, Federal Sentencing Guidelines $\S 2 D 1.1$ at 198 (cited in note 127), despite the fact that crack and cocaine are identical chemically and probably possess the same addictive and abusive potentials. Because black Americans are more likely to use crack, and white Americans cocaine, the effect of this has been to place huge numbers of the blacks in jail while equally culpable whites remain unincarcerated. Noting these facts, Attorney General Reno and "Drug Czar" Barry McCaffrey have urged that this disparity be reduced to 10 to 1 by invoking the five-year minimum mandatory sentence on defendants possessing either 25 grams of crack (instead of the current 5 gram threshold) or 250 grams of powder cocaine. Christopher S. Wren, Reno and Top Drug Official Urge Smaller Gap in Cocaine 
As investigations in several jurisdictions have documented, criminal defendants with the most assets to forfeit routinely serve shorter prison sentences and sometimes no prison sentence at all. In New Jersey, for example, a defendant facing a "drug kingpin" indictment (twenty-five years to life) obtained a dismissal of that charge and parole eligibility in five years on a lesser conviction, by agreeing to forfeit over $\$ 1$ million in assets. ${ }^{130}$ In Massachusetts, a recent investigation by journalists found that on average a "payment of $\$ 50,000$ in drug profits won a 6.3 year reduction in a sentence for dealers, ${ }^{\text {"131 }}$ while agreements to forfeit $\$ 10,000$ or more bought elimination or reduction of trafficking charges in almost three-fourths of such cases. ${ }^{132}$ The Massachusetts prosecutors who were investigated have a com-

Sentences, NY Times A1 (July 22, 1997). Another critic of the 100 to 1 disparity, Suffolk County, Massachusetts District Attorney Ralph Martin, says that it has "encouraged federal law enforcement officers to treat street-level crack dealing as a major offense, draining resources away from major drug kingpins." Adrian Walker, The Drug War: Two Wrongs to Right, Boston Globe E1 (July 27, 1997).

${ }^{130}$ The forfeited assets were then distributed among the prosecutor's office and participating law enforcement agencies. Martin Haines, Prosecutors and Criminals Sharing Wages of Crime, NJ L J 17 (Oct 19, 1992).

${ }^{131}$ Dick Lehr and Bruce Butterfield, Small Timers Get Hard Time, Boston Globe Metro 1 (Sept 24, 1995).

${ }^{132}$ Dick Lehr and Bruce Butterfield, Accused's Assets are Key Chips in Plea Bargains, Boston Globe Metro 1 (Sept 25, 1995). These articles were parts of a four-part series titled Criminal Justice/Overdosing on the Drug War, published by the Boston Globe from Sept 24 through Sept 27, 1995.

The investigation, by Boston Globe reporters, included a comprehensive examination of prosecution records from the four largest Massachusetts counties, as well as numerous case studies comparing defendants who were similarly situated except for their assets. For example, one defendant who sold cocaine to lower-level dealers was able to reduce a "mandatory" fifteen-year sentence to two and a half years served; another defendant-less culpable in that undercover agents ran him through five relatively small drug buys before arrest in order to reach a level of quantity that would qualify him for a ten-year sentence-received the full ten years. The difference was that the first defendant had $\$ 460,000$ in forfeitable bank deposits to offer in lieu of hard time. Id at Metro 1.

In another, more celebrated case brought in Florida, the defendant escaped a life sentence by forfeiting yachts, his home, and millions of dollars in cash. See Mireya Navarro, When Drug Kingpins Fall, Illicit Assets Buy a Cushion, NY Times A1 (Mar 19, 1996); John Gibeaut, F. Lee Bailey's New Digs, ABA J 24 (May 1996) (discussing United States v Duboc, unpublished district court opinion (N D Fla 1994)). This case attracted substantial attention, initially because attorney F. Lee Bailey was incarcerated for failing to turn over client properties the government claimed as its own. But a byproduct of the media's interest was that the public was given "a rare look at the usually secretive world of plea bargaining in big drug cases, ... . [opening] a window on a growing controversy in narcotics prosecutions in Florida and across the nation: how rich defendants like $\mathrm{Mr}$. Duboc use the proceeds of their crimes to bargain for lighter sentences." Navarro, NY Times at A1. One former prosecutor said that the case "gives forfeiture a bad name. The point of forfeiture is to strip assets from the bad guys, not to make money for the government." Gibeaut, ABA J at 25 . 
pelling reason to recalibrate the scales of justice in this way because 12 percent of their budgets are financed through forfeiture income. ${ }^{133}$ And the Supreme Court has facilitated this practice by finding no right to a judicial inquiry as to whether property relinquished pursuant to a guilty plea is properly subject to forfeiture. ${ }^{134}$ As Justice Stevens noted in dissent, "it is not unthinkable that a wealthy defendant might bargain for a light sentence by voluntarily 'forfeiting' property to which the Government had no statutory entitlement. ${ }^{135}$ But these distorted, disparate plea offers remain untested under the due process right to an impartial prosecutor, and the most hopeful challenge may come from the asset-poor defendants who suffer the most in plea bargaining from the government's conflict of interest. ${ }^{136}$

To illustrate the extent of a suspect's stake in uncorrupted law enforcement, we present a final example: the enlightening and appalling case of Donald Scott. Scott was a sixty-one year-old wealthy recluse who owned a two hundred acre ranch in Malibu, California adjacent to a large recreational area maintained by the National Park Service. In 1992, the Los Angeles County Sheriff's Department ("LASD") received an informant's report that Scott was growing several thousand marijuana plants on his land. The LASD assembled a team-including agents from the Los Angeles Police Department, the DEA, the Forest Service, the California Air National Guard, the Border Patrol, and the California Bureau

${ }^{153}$ Lehr and Butterfield, Accused's Assets, Boston Globe at Metro 1 (cited in note 132).

${ }^{134}$ See Libretti $v$ United States, 116 S Ct 356, 362-63 (1995). Libretti refutes one claim that is sometimes made, that prosecutorial conflicts are not dangerous because so long as there is an impartial tribunal down the line, any abuses can be corrected. So does the Jerrico opinion, only more explicitly. See Jerrico, 446 US at 249-50 ("[T] force-or not to enforce-may itself result in signficant burdens on a defendant . . . even if he is ultimately vindicated in an adjudication."); Ward, 409 US at 61-62 (opportunity for trial de novo does not obviate the need for an impartial tribunal at the first hearing).

${ }^{135}$ Libretti, $116 \mathrm{~S} \mathrm{Ct}$ at 370 (Stevens dissenting). Justice Stevens continued, "No matter what a defendant may be willing to pay for a favorable sentence, the law defines the outer boundaries of a permissible forfeiture. A court is not free to exceed those boundaries solely because a defendant has agreed to permit it to do so. ... Were a court to do otherwise, it would permit the parties to define the limits of its power." Id at 370-71.

${ }^{136}$ Although wealthy defendants may be targeted in the investigatory stage, in the plea bargaining context the ultimate losers are the defendants without assets to trade for time. The harsher treatment they receive is a direct result of the prosecutor's conflicting financial interest, and thus should be cognizable under the Due Process Clause. An additional argument stems from the recent, unanimous Supreme Court decision in Bracy $v$ Gramley, 117 S Ct 1793 (1997), which held that a corrupt judge's favoritism toward other defendants who bribed him may have violated the petitioner's right to an impartial trial by giving the judge a motive to camouflage his lenient treatment with a conviction: it would violate due process if the judge "was biased in this . . . compensatory sense . . . to avoid being seen as uniformly and suspiciously 'soft' on criminal defendants." Id at 1797. 
of Narcotic Enforcement-to investigate the tip, largely through the use of air and ground surveillance missions. Despite several unsuccessful efforts to corroborate the informant's claim, ${ }^{137}$ and despite advice that Scott posed little threat of violence, ${ }^{138}$ the LASD dispatched a multijurisdictional team of thirty law enforcement officers to conduct a military-style raid. On October 2, 1992 at 8:30 am, the officers descended upon the Scott ranch to execute their search warrant. After knocking and announcing their presence, they kicked in the door and rushed through the house. There they saw Scott, armed with a gun in response to his wife's screams. With Scott's wife watching in horror, they shot and killed him. There were no marijuana plants anywhere on the land, and no drugs or paraphernalia in the house.

Following Scott's death, the Ventura County District Attorney's Office conducted a five-month investigation of the raid. The seventy-page report found no credible evidence of present or past marijuana cultivation on Donald Scott's property. ${ }^{139}$ As for the search warrant, the report found that much of the information supporting the warrant was false, that exculpatory surveillance evidence was withheld from the judge, and that the LASD knowingly sought the warrant on legally insufficient information. ${ }^{140}$ The search warrant 'became Donald Scott's death warrant," the report concluded, and Scott was unjustifiably, needlessly killed. ${ }^{141}$

The targeting of Donald Scott, with its massive multijurisdictional police presence, cannot be explained as any kind of crime control strategy. Rather, as the Ventura County District Attorney's report concluded, a purpose of this operation was to garner

${ }^{137}$ Report on the Death of Donald Scott 37-41 (Office of District Attorney, Ventura County, Cal, Mar 30, 1993). Aerial photographs of the ranch did not show any marijuana plants. But Charles Stowell, a federal DEA agent, took another flight over the ranch and made the claim, hardly plausible under the circumstances, that he was able to identify about fifty marijuana plants by their "distinct color." (Stowell viewed the ranch from an altitude of one thousand feet without binoculars. The usual procedure of photographing the suspect patch was not followed. Nor did the patch's relatively small size conform to the informant's report.) Then the Border Patrol conducted two ground reconnaissance missions onto the Scott property. These searches-which could not be justified under the Border Patrol's mandate to enforce federal immigration laws-found no evidence of marijuana cultivation.

${ }^{138}$ Id at 11-12.

${ }^{139}$ Id at $37-41$.

${ }^{140}$ The report found that the supporting affidavit asserted falsely that ground surveillance had confirmed the presence of the plants and that the agent had used binoculars, failed to reveal the unfavorable surveillance results, and that the affidavit contained numerous other misleading statements. Id at 42.

"is Id at 62. 
the proceeds from the forfeiture of Scott's \$5 million ranch. Among the documents distributed to some of the officers at the pre-raid briefing were a property appraisal of Scott's ranch, a parcel map of the ranch with a reference to the sales price of a nearby property, and a statement that the ranch would be seized if fourteen marijuana plants were found. ${ }^{142}$

Egregious cases like Donald Scott's underscore the difference between the statutory provision upheld in Jerrico and laws that encourage law enforcement agencies to finance themselves through aggressive, potentially violent police actions-a difference that threatens liberty and even life in ways that no one can mistake for "due process of law." Moreover, for a court to find otherwise would betray one of the central concerns that led to the founding of our constitutional order. Financial incentives promoting police lawlessness and selective enforcement, in the form of the customs writs of assistance, were among the key grievances that triggered the American Revolution. ${ }^{143}$ Writs of assistance authorized customs officers to seize suspected contraband and to retain a share of the proceeds, often a third, for themselves and their informants. ${ }^{144}$ From the viewpoint of the Crown, this incentive helped to ensure that goods landing in American ports were taxed or, if prohibited, confiscated. But for the colonists, it was an outrage that brought with it corrupt officials, ${ }^{145}$ lawless sei-

${ }^{14}$ Id at 16. Although the ranch was situated in Ventura County, the report noted that the Ventura County Sheriffs Department was not included in the investigation or the raid, perhaps in order to avoid sharing the proceeds with it. Id at 50-52.

${ }^{143} \mathrm{John}$ Adams, a student of the writs of assistance cases, wrote that public outcry against the writs of assistance was one of the sparks leading to American independence, as discussed in Smith, The Writs of Assistance at 251-56 (cited in note 2). For discussion and additional authorities on this point, see Tracey Maclin, When the Cure for the Fourth Amendment is Worse than the Disease, $68 \mathrm{~S} \mathrm{Cal} \mathrm{L} \mathrm{Rev} \mathrm{1,} \mathrm{15-25} \mathrm{(1994).}$

${ }^{14}$ See Smith, The Writs of Assistance at 13 (cited in note 2) ("[T]he acts of navigation and trade gave one-third each to the king, the governor of the particular colony, and the customs man."). Informants were commissioned by customs officers; newspaper advertisements seeking informants promised that they would be "handsomely rewarded, and their Names concealed ...." Id at 128. Condemnations were extremely profitable for both, not least because, rather than reveal their identities, smugglers chose not to challenge the seizures. Id at 13. See also Nelson B. Lasson, The History and Development of the Fourth Amendment to the US Constitution 57 n 24 (Da Capo 1970), quoting Lieutenant Governor Thomas Hutchinson's remark that Massachusetts Governor Bernard "was very active in promoting seizures for illicit trade, which he made profitable by his share in the forfeitures."

${ }^{145}$ Writs of assistance were sought by people in need of money, and disreputable men were hired as informants. See Smith, The Writs of Assistance at 128 (cited in note 2). Because seized contraband was unlikely to be disputed in court, customs officers could often falsify the inventory of seized items, or as the Boston Gazette reported on Feb 16, 1761, "goods [were] inventoried by false names in order that another disposition of them might 
zures, ${ }^{146}$ selective enforcement, ${ }^{147}$ fabricated evidence, ${ }^{148}$ extortionary agreements from subjects with no effective legal recourse, ${ }^{149}$ "and even the fatal consequences, which may arise from the execution of a writ of assistance, only to put fortunes into private pockets. ${ }^{.150}$ From these complaints "the child Independence was born."151 The same fundamental grievances are now lodged against our present forfeiture laws. What court can read such formative concerns out of the Constitution?

\section{B. Policy Objections}

There are many issues in the criminal justice arena that set the constitutional rights of suspects against the security of the general population. The Drug War's economic incentive structure is unusual in that it threatens the due process of drug suspects and hinders effective law enforcement at the same time. For example, when police target drug buyers rather than sellers in order to advance their own financial interest they brazenly ignore the public interest in both just, proportional punishment and drug reduction. Bad policy may not be unconstitutional, but it

be made." Id at 170. For discussion on analogous problems today, see text accompanying notes 238-55.

${ }^{146}$ Otis, Article, in Smith, The Writs of Assistance at 562-63 (cited in note 2) (delivering tirade against lawless searches under the writ). For discussion on the analogous problem today, see text accompanying notes 244-55.

${ }^{147}$ The laws were enforced selectively, with custom officers leaving alone their close merchant associates. See Smith, The Writs of Assistance at 101 (cited in note 2).

${ }^{143}$ Id at 563. An earlier English analogue, the "Reward Statutes" of 1692, which paid informants for information leading to convictions, was discontinued in 1754 after several innocent people were executed on false information provided for the reward money. See John H. Langbein, Shaping the 18th Century Criminal Trial: A View from the Ryder Sources, 50 U Chi L Rev 1, 106-14 (1983). For discussion on the analogous problem today, see note 254 and accompanying text.

${ }^{149}$ The procedural advantages the Crown enjoyed resemble those confronting modern day forfeiture claimants. If the property was used in commerce, then each day spent fighting to establish a claim was another day's business lost. Consequently in colonial admiralty court, officials and property owners struck deals that placed the owner in the peculiar position of paying the state for the return of property. (Because colonial juries were unsympathetic, the Crown had transferred jurisdiction to admiralty judges in 1696.) There is one case of a subject who, having made such a bargain to get back his ship and cargo, sued under common law trespass for damages and prevailed. See Smith, The Writs of Assistance at 181 (cited in note 2). For discussion on similarly coercive plea bargains enforced today, see text accompanying notes 130-36.

${ }^{150}$ Otis, Article, reprinted in Smith, The Writs of Assistance at 565 (cited in note 2) (capitalization omitted).

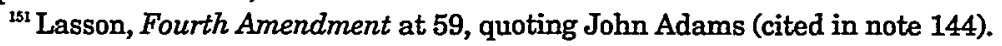


does demand reform-in this case, obvious reforms that could be easily legislated if there were the political will to do so. ${ }^{152}$

Imposing this conflict of interest on law enforcement endangers the public welfare in four critical areas. First, encouraging police to target assets undermines drug law enforcement strategies. Nominally, forfeiture provides a way to remove contraband from circulation. But when fundraising prospects lead police to defer arrests until after drug sales, ${ }^{153}$ when police prefer to target the least culpable offenders, ${ }^{154}$ when prosecutors give leniency to those dealers with the largest assets, and when 80 percent of the people whose assets are seized are never charged, ${ }^{155}$ we should suspect that the forfeiture payback provision is having the opposite effect. Virtually all drug enforcement decisions are subject to this economic temptation; heroin distribution may demand more enforcement, for example, but perhaps targeting cocaine dealers would be more profitable. ${ }^{156}$ One commentator concluded that "forfeiture is shaping the core goals and policies of the [Drug War]. ... Asset forfeitures have become a legitimate alternative policy goal for law enforcement[,] . . an end in themselves. ${ }^{\text {1157 }}$

The forfeiture incentive exerts all the more influence because no clear drug control priorities have ever been formulated that

${ }^{152}$ This is particularly so because the most obvious legislative reform, which is requiring forfeited assets to be deposited in the general fund rather than funneling them to the seizing agency, would eliminate the destructive incentives we have described. Additionally, it would not reduce whatever benefits the forfeiture law can deliver-whether measured in terms of drug enterprises shut down, contraband seized, drug dealers deterred, or even the conversion of drug proceeds into government revenue. We address this and other potential legislative reforms in Section IV.

${ }^{133}$ See text accompanying note 121.

${ }^{154}$ Although forfeiture may have been intended for prosperous kingpins and large enterprises, many law enforcement agencies have decided that it is most advantageous to pursue the more numerous low-level dealers or users. See, for example, Inequity Seen in Drug Forfeiture Law, NY Times A17 (Sept 3, 1993) (reporting that 94 percent of the six thousand forfeiture cases filed by San Jose prosecutors in 1992 involved less than $\$ 5,000$ ). Small seizures have two advantages: the forfeiture opportunities are virtually endless, and claimant challenges to them are impractical because they would cost more than the amounts involved. See also JRSA, Five-Year Review at 23 (cited in note 1) (suggesting task force members consider "whether it is more efficient to target major dealers or numerous smaller ones").

${ }^{155}$ Andrew Schneider and Mary Pat Flaherty, Drug Law Leaves Trail of Innocents, Chi Trib C1 (Aug 11, 1991) (reporting on a nationwide survey of forfeitures over a ten-month period). Another investigation of Volusia County, Florida forfeitures found that no charges were filed in three out of four forfeitures. Jeff Brazil and Steve Berry, Tainted Cash or Easy Money?, Orlando Sent Trib A1 (June 14, 1992).

${ }^{156}$ See Miller and Selva, 11 Justice $Q$ at 314-16 (cited in note 113) (concluding that the funds available through asset forfeiture caused police to concentrate on less serious cases and did not result in diminishing the quantity of drugs on the street).

${ }^{157}$ Nelson, Comment, $80 \mathrm{Cal} \mathrm{L}$ Rev at 1327 (cited in note 41). 
might act as a restraint on single-minded fundraising. Because questioning any Drug War campaign can be political suicide, its priorities have rarely been subject to rational public debate. Shrill political demands that everything be accomplished immediately reduce to a directionless program in which nothing takes precedence. The euphemistic label attached to this abdication is the "zero tolerance policy," formally adopted by the National Drug Policy Board on March 21, 1988. ${ }^{158}$ This "policy" has authorized virtually any law enforcement activity that has even the most tenuous connection to drug violations-effectively a license to engage in unlimited asset seizures. Pursuant to this policy, the Customs Service and the Coast Guard have seized assets regardless of whether the owner was innocent or possessed merely a de minimis quantity of drugs. In May 1988, for example, the Coast Guard seized a yacht valued at $\$ 2.5$ million because it contained one-tenth of an ounce of marijuana. ${ }^{159}$ Similarly, the Reagan "Just Say No" campaign equated casual, recreational marijuana use with the most desperate forms of drug addiction, making any and all law enforcement choices acceptable. ${ }^{160}$

Second, by linking police budgets to drug law enforcement, both forfeiture laws and Byrne grants induce police and prosecutors to neglect other, often more pressing crime problems. ${ }^{161}$ From the examples in the preceding section, it should be evident that law enforcement officials now make business judgments that can only compete with, if not wholly supplant, their broader law enforcement goals. The Department of Justice has periodically made this practice official policy, as in 1989 when all U.S. Attorneys were directed to divert resources to forfeiture efforts if nec-

${ }^{158}$ Smith, Forfeiture II 1.02 at 1-12 (cited in note 44) (calling the policy "indiscriminate and overzealous"). See also Representative Charles B. Rangel, Reagan's 'Zero Tolerance' is a Zero Drug Policy, Newsday 66 (June 28, 1988).

${ }^{159}$ The yacht was later returned to its absentee owner. See Smith, Forfeiture II 1.02 at 1-12 $\mathrm{n} 17$ (cited in note 44).

${ }^{160}$ Some have criticized the Drug War as geared to protecting suburbia and the middle class while failing to address the more destructive problem in the inner cities. Robert Stutman, formerly head of the DEA New York office, notes that "[b]efore 1966 we concentrated purely on heroin and nobody paid attention. The predominant attitude among most Americans, and certainly most agents, was, Who cares who sells it as long as only black people are using it?' ... [But then drugs began] leaving the ghetto, so all of a sudden they were becoming understood as a truly American problem." Robert M. Stutman and Richard Esposito, Dead on Delivery: Inside the Drug Wars, Straight from the Street 67-68 (Warner 1992). Stutman and Esposito bemoan the emphasis on law enforcement to the exclusion of treatment, education, and other non-criminal approaches.

${ }^{161}$ See, for example, Steven Wisotsky, Crackdown: The Emerging "Drug Exception" to the Bill of Rights, 38 Hastings L J 889, 898 (1987) (concluding that drug enforcement is now the "top priority, indeed the organizing focus" of the federal criminal justice system). 
essary to meet their commitment "to increase forfeiture production":

If inadequate forfeiture resources are available to achieve the above goals, [U.S. Attorneys] will be expected to divert personnel from other activities or to seek assistance from other U.S. Attorneys' offices, the Criminal Division, and the Executive Office for United States Attorneys. ${ }^{162}$

The asset retention law compounds already existing incentives that promote an inordinate emphasis on drug enforcement. For example, personal rewards often accrue to those police officers who most zealously enforce the drug laws. Because drug detail generally reaps large numbers of nighttime arrests and daytime court appearances for the arresting officer, ${ }^{163}$ it is an avenue to both overtime pay (sometimes equaling base salary) and better evaluations (which are often linked to arrest rates). ${ }^{164}$ This both channels officers into drug enforcement and pits their personal interest against noncriminal, community-based alternatives to arrest.

${ }^{162}$ Directive 89-1 at 2, in DOJ Asset Forfeiture Manual at B-584.71 (cited in note 103). See also Directive 91-7 at 9, in DOJ Asset Forfeiture Manual at B-567 (cited in note 68) ("The Attorney General has made asset forfeiture one of the Department of Justice's highest law enforcement priorities.").

${ }^{1 \infty}$ The reason for this lies in the nature of drug law enforcement, much of which occurs at night. Officers may time arrests to coincide with the end of a shift in order to generate overtime pay for processing the arrest. Commission to Investigate Allegations of Police Corruption and the Anti-Corruption Practices of the Police Department, City of New York, Anatomy of Failure: A Path for Success 39 (July 7, 1994) ("Mollen Commission Report"). Moreover, because there are few triable issues when a suspect is caught selling or possessing drugs, most drug cases are disposed of quickly by plea bargain, Mollen Commission Report at 37, and the officer may be able to claim a day's overtime pay for a brief appearance in court. See, for example, Mark Bowden and Mark Fazlollah, Rogue Cops: Officers Rode Roughshod, Got Away with It, Phil Ing A1 (Sept 11, 1995) (part two of a threepart series).

${ }^{164}$ Bowden and Fazlollah, Phil Inq at A1. Bowden and Fazlollah report that "every collar on the night shift afforded the opportunity of overtime pay. A day in court could mean $\$ 100$ to $\$ 200$ in extra earnings. That year [Officer Baird]. . . earned nearly half again as much in overtime ...." Id. As the authors explain, "with pressure from all quarters to do something about drugs, things like arrest totals and conviction rates offer at least paper proof that the battle is being waged." Id.

The benefits that flow from high arrest rates have been condemned for encouraging false arrests, and sometimes perjury as to the identity of the arresting officer ("trading collars for dollars"). Mollen Commission Report at 39.(cited in note 163); Richard Emery, The Even Sadder New York Police Saga, NY Times A3I (Dec 12, 1987) (concerning New York transit police arrest quotas). They also promote incarceration over treatment, prevention, and other problem-solving approaches. See generally Andrew Schneider and Mary Pat Flaherty, Government seizures victimize innocent, Pittsburgh Press (Aug 11-16, 1991) (six-part series). 
Police forces desperately pursuing drug offenders are, of course, just the beginning of a spiral that is spinning out of control. To complete the picture, one must also examine the non-drug crimes that go unprevented or uninvestigated, the court hours diverted from other kinds of cases ${ }^{165}$ the rejection of non-criminal approaches to dealing with the drug problem, and much more. Unfortunately, Congress has diligently avoided examining these issues.

This brings us to a third casualty of the funding methods we have described: the subversion of any serious legislative debate on our drug policy, and particularly on how heavily it should rely on law enforcement as the solution rather than alternative noncriminal strategies. There is, for example, an enormous body of research to show that treatment is several times more effective in reducing drug consumption than interdiction and other policing. ${ }^{166}$ Yet from the beginning, national drug policy overwhelmingly has emphasized law enforcement rather than treatment, education, or other noncriminal approaches. Out of approximately $\$ 15$ billion in annual federal Drug War funds, approximately two-thirds are dedicated to law enforcement and interdiction. ${ }^{167}$ Meanwhile the slim budgetary allotment for the Substance Abuse and Mental Health Administration's prevention

${ }^{165}$ For example, between 1980 and 1990 the number of federal drug convictions rose more than 300 percent, almost ten times the increase in nondrug convictions. Douglas $\mathbf{C}$. McDonald and Kenneth E. Carlson, Federal Sentencing in Transition, 1986-90 4 (DOJ 1992). See also Judicial Conference of the United States, Long Range Plan for the Federal Courts 12 (Dec 1995) (noting that from 1972 to 1994, federal drug prosecutions rose from 18 percent to 40 percent of the federal criminal dockets); Dan Baum, The Drug War on Civil Liberties, The Nation 886, 887 (June 29, 1992) (reporting that Chief Justice Rehnquist chastised the Justice Department for burdening federal courts with petty drug cases); Kathleen F. Brickey, Criminal Mischief: The Federalization of American Criminal Law, 46 Hastings I J 1135, 1150-58 (1995) (concluding that mushrooming federal drug prosecutions are overwhelming the federal courts).

${ }^{166}$ See, for example, Treatment: Effective (But Unpopular) Weapon Against Drugs, 19 RAND Research Rev 3, 3 (Spring 1995) (reporting RAND study concluding that treatment is seven times more cost-effective than supply-control programs in reducing cocaine consumption).

${ }^{167}$ Of the federal funds allocated to the drug war, the fraction devoted to law enforcement and interdiction generally has hovered around two-thirds. Compare the Bush administration statistics, reported in Massing, What Ever Happened to the War on Drugs??, NY Rev of Books at 45 (cited in note 11) ("[T]wo-thirds, or more than $\$ 8$ billion goes for law enforcement and interdiction .... "), citing the White House, National Drug Control Strategy, Budget Summary 2 (Jan 1992), with the Clinton 1998 proposed budget, reported in Robert Dreyfuss, Hawks and Doves, Rolling Stone 42, 42 (Aug 7, 1997) (reporting that 66 percent of Clinton drug budget will go towards law enforcement and military interdiction). 
and treatment programs was cut by 60 percent in $1996 .{ }^{168}$ The forfeiture incentive-along with Byrne funding, the additional monetary and career rewards that flow to police officers who make drug arrests, ${ }^{169}$ and a mushrooming prison-dependent economic sector ${ }^{170}$-assures the existence of a powerful lobby to maintain this imbalance. ${ }^{171}$ As we demonstrate in Section $T V$, this lobby has been able to soundly defeat the few congressional efforts to divert some drug law enforcement funding to other uses.

While this law enforcement emphasis has not diminished our drug problem, it has produced a prison problem of staggering proportions. With a fivefold increase in the number of incarcerated drug offenders over the last decade, ${ }^{172}$ the Drug War has given us the second most incarcerated population in the industrialized world, after Russia. ${ }^{173}$ Over ten years, we have doubled our prison population to 1.6 million inmates, requiring the addition of

${ }^{168}$ Wren, NY Times at A1 (cited in note 5) (reporting that funding for the Department of Health and Human Service's Substance Abuse and Mental Health Administration drug prevention program, and for Administration's treatment programs, were cut in 1996 to $\$ 89$ million for each-a cut of about 60 percent from 1995, which resulted in the closing of seventy-nine prevention programs and thirty-three treatment programs).

${ }^{100}$ The monetary and career benefits that flow to officers from high arrest rates have been condemned for promoting incarceration over treatment, prevention, and other problem solving approaches. Like forfeiture except at a more directly individual level, this incentive juxtaposes the officer's self-interest against non-criminal, community-based alternatives to arrest.

${ }^{170}$ The prison-dependent economic sector also includes businesses that will share in the $\$ 10$ billion to be spent in prison construction over the next five years pursuant to the Crime Control Act of 1996, Pub L No 104-134, 110 Stat 1321-19 (1996), codified at 42 USCA \& 13708(a)(1) (West 1997).

${ }^{171}$ For example, a survey revealed that an unsurprising 90 percent of task force commanders thought task forces should be a top priority for funding; 64 percent said they should have priority over education or treatment programs, compared to 17 percent who thought they should have less priority. Coldren, et al, Multijurisdictional Task Force Operations at $10 \&$ exh 6 (cited in note 33). See also Dreyfuss, Rolling Stone at 46 (cited in note 167), quoting the former police chief of Kansas City, Missouri, Joseph McNamara, as saying that he long ago concluded that the Drug War "is irrational, racist, un-American and unsuccessful" and wrote a dissertation that "was so critical of our drug policy that I never published it. If I had, I never would have had a career in law enforcement."

${ }^{172}$ Mauer and Huling, Young Black Americans at 10 (cited in note 8). Between 1986 and 1991 there was an 828 percent increase in black, non-Hispanic females incarcerated for drug offenses in state prison. Id at 20. In California, the growth rate of incarcerated drug offenders was even higher: 1500 percent during the 1980s. Franklin E. Zimring and Gordon Hawkins, Prison Population and Criminal Justice Policy in California 32-35 (Berkeley 1992).

${ }^{173}$ Mauer and Huling, Young Black Americans at 23 (cited in note 8). The authors report that the average length of time served by drug offenders increased 50 percent between 1986 and 1992, from twenty-two to thirty-three months. Id at 11. They also note that a drug arrest in 1992 was four times more likely to result in incarceration than in 1980. Id at 10. 
1,600 new prison beds each week. ${ }^{174}$ None of this has affected the spread of serious addiction among school dropouts, gang members, and the poor, except by siphoning away funds that might be used for drug education, treatment, or the amelioration of hardships that make drug abuse look attractive to the disadvantaged.

Fourth and finally, the economic rewards offered by both the forfeiture and Byrne grant laws are so large that some police are tempted to pursue them illegally when necessary. ${ }^{175}$ A recent federal civil rights case brought against several task force officers strikingly illustrates the corrosive operation of these incentives. In United State $v$ Reese, ${ }^{176}$ the Ninth Circuit described a task force criminally deformed by its dependence on federal drug money. Existing as a separate unit within the Oakland Housing Authority, the task force operated, in the words of one member, "more or less like a wolfpack," driving up in police vehicles and taking "anything and everything we saw on the street corner." ${ }^{\text {"177 }}$ According to the court, the commander, Daniel Broussard,

regularly exhorted Task Force officers to keep their arrest numbers up. All the officers were aware that the federal grant that funded their unit, and on which their jobs depended, was good for only eighteen to twenty-four months. Broussard warned that they would need statistics to show that the federal money was well spent and thus to secure another grant. On more than one occasion, he sent the Task Force out to begin a shift with comments like, "Let's go out and kick ass," and "[E]verybody goes to jail tonight for everything, all right?"'178

${ }^{174}$ Michael Sniffen, Incarceration Rate Doubled in 10 Years, Charleston Gaz $1 \mathrm{~A}$ (Aug 19,1996 ), relying on the Justice Department's Bureau of Justice Statistics Report of Aug 18,1996 . The same report also indicated that 1 of every 167 Americans is incarcerated, compared with 1 in 320 a decade earlier. 5.3 million people, almost 3 percent of the adult population, are now in prison, on parole, on probation, or otherwise supervised by a criminal justice agency. DOJ, Press Release: Probation and Parole Population Reaches Almost 3.8 Million (1996).

${ }^{175}$ Byrne grants do not pose the same conflict of interest problems that forfeiture laws do. When Byrne-funded task forces target drug offenders they are not redefining their goals for financial self-interest; drug enforcement is the goal that Congress has assigned to them. However, as the discussion of United States v Reese, 2 F3d 870 (9th Cir 1993), will demonstrate, providing soft money for drug law enforcement creates incentives that similarly divert police officers from the proper execution of their jobs.

${ }^{176} 2$ F3d 870 (9th $\operatorname{Cir} 1993$ ).

${ }^{m}$ Id at 874.

${ }^{178}$ Id. Broussard also told his men that "a lot of 'dirty' drug money would be passing through their hands, and that it would not really matter if they kept some of it for themselves" because the suspects would be in no position to complain. Id. 
Oakland's drug task force is far from unique. Reporters and investigators have documented numerous other instances where police departments engaged in illegal searches, threats, and other lawless conduct in search of forfeitable cash. After viewing videotapes of approximately one thousand highway stops, two Florida reporters found that police had used traffic violations as a pretext to confiscate "tens of thousands of dollars from motorists against whom there [was] no evidence of wrongdoing," commonly taking the money without filing any criminal charges. ${ }^{179}$ Other police departments treat significant cash on hand as a sign of presumptive guilt. ${ }^{180}$ A Los Angeles Sheriff's Department employee reported that deputies routinely planted drugs and falsified police reports to establish probable cause for cash seizures. ${ }^{181}$ According to news reports, Louisiana police engaged in massive pretextual stops, with the seized money diverted to police department ski trips and other unauthorized uses. ${ }^{182}$ Many of these police undertook such lawlessness not to acquire illicit personal income, but to further their agency's financial well-being. As we note below, the Drug War also has fostered the more traditional kinds of police corruption and private graft that particularly thrive in the surreptitious, informant-laden world of anti-drug operations. ${ }^{183}$

${ }^{179}$ Brazil and Berry, Tainted Cash, Orlando Sent Trib at A1 (cited in note 155). Blacks and Hispanics constituted more than 80 percent of the drivers searched, but only a small fraction of the drivers on the patrolled highway. Jeff Brazil and Steve Berry, Color of Driver is Key to Stops in I-95 Videos, Orlando Sent Trib A1 (Aug 23, 1992).

${ }^{100} \mathrm{See}$, for example, Heilbroner, NY Times $\$ 6$ at 70 (cited in note 47). Heilbroner reports that police in the small town of Sulphur, Louisiana seized about $\$ 5$ million in four years, more than the entire New Orleans police force. "Typically, a speeder is pulled aside. When a lot of cash is found on him and his explanation is suspect, a drug dog is summoned. If the dog smells narcotics, the police seize the money." Id. As detailed in note 47, most paper currency is now contaminated and tests positive for cocaine.

${ }^{181}$ Kenneth Reich and Victor Merina, Ex-Sergeant Sentenced, Alleges Misconduct, LA Times B1 (Apr 13, 1993), quoting LA County Sheriff's Sergeant Robert Sobel, "The falsification of police reports is rife. . . . These seizures [were] legal street robberies." Id. Sobel made these accusations after pleading guilty in a corruption probe.

${ }^{102}$ See Dateline NBC, Probable Cause?: Policemen in Louisiana harass motorists and seize their property for no apparent reason, 1997 WL 7754554 (Jan 3, 1997). Although such traffic stops were pretexts for forfeiture fund-raising, a recent Supreme Court decision largely excludes ulterior motives from Fourth Amendment analysis by holding that the existence of probable cause renders such motives irrelevant. Whren $v$ United States, $116 \mathrm{~S}$ Ct 1769, 1776 (1996) (rejecting as irrelevant defendants' claim that vehicle stops targeted blacks). For a critique of the Court's analysis, see Tracey Maclin, Race and the Fourth Amendment, 51 Vand L Rev (forthcoming Mar 1998).

${ }^{103}$ See notes $253-55$ and accompanying text. 


\section{ThE ACCOUNTABILITY OBJECTIONS TO SELF-FINANCING POLICE AGENCIES}

\section{A. The Separation of Powers Objection}

We turn now to a second fundamental problem with selffinancing law enforcement agencies: inadequate accountability. Agencies that can finance themselves through asset seizures need not justify their activities through any regular budgetary process. As a Department of Justice report notes, "one 'big bust' can provide a task force with the resources to become financially independent. Once financially independent, a task force can choose to operate without Federal or state assistance."184

When this happens, the predictable consequence is a degree of police secrecy and independence that brings with it some of the risks civil libertarians associate with the term "police state." We do not mean to imply that police now exercise unlimited power in the United States, but we do believe that the escalating presence of this new kind of police agency will prove increasingly dangerous to our nation's liberty if left unchecked. The longer we ignore this problem, the more entrenched and intractable it will become.

As with the conflict of interest problem in the preceding section, police unaccountability invokes both constitutional and policy objections. We explore the latter concerns in Section III.B. In this Section we argue that independent, self-financing law enforcement agencies violate both the Appropriations Clause and the separation of powers framework that the clause was designed to support.

Under Article I, Section 9, Clause 7 of the Constitution, Congress is vested with exclusive appropriations power. ${ }^{185}$ Along with supporting statutes-including the Miscellaneous Receipts Act (which requires all funds collected to be deposited in the public treasury, subject to few exceptions ${ }^{186}$ ), the Anti-Deficiency Act (which bars a government employee from authorizing or incurring an obligation without a congressional appropriation ${ }^{187}$ ), and

${ }^{184}$ JRSA, Five-Year Review at 9 (cited in note 1).

${ }^{185}$ This clause provides: "No Money shall be drawn from the Treasury, but in Consequence of Appropriations made by Law; and a regular Statement and Account of the Receipts and Expenditures of all public Money shall be published from time to time."

${ }^{186}$ Government funds coming into the hands of an officer or agent of the United States must be paid "as soon as practicable" into the Treasury. Pub L No 97-258, 96 Stat 948 (1982), codified at 31 USC $\S 3302(b)$ (1994).

${ }^{187}$ Pub L No 97-258, 96 Stat 923 (1982), codified at 31 USC $\S 1341(a)(1)$ (1994) ("An officer or employee of the United States Government may not make or authorize an expenditure or obligation exceeding an amount available in an appropriation or fund for the ex- 
the prohibition against augmentation (which bars an agency from exceeding the amount appropriated with third-party funding ${ }^{188}$ )the Appropriations Clause assures that government income cannot be spent until a specific congressional appropriation releases it. ${ }^{189}$

By contrast, under 21 USC $\S 881(\mathrm{e})(2)(\mathrm{B})$, money seized by a federal agency is deposited in the Department of Justice's Asset Forfeiture Fund, where it is then available to the Department and other federal agencies for drug law enforcement and, in some cases, prison funding. ${ }^{190}$ This arrangement bypasses the Treasury, leaving the Department of Justice free to determine the contours of its own budget. The Department of Justice, the DEA, and other federal law enforcement agencies have essentially been given the freedom to fund themselves in whatever amount their agents can legally seize. The constitutional questions are whether this kind of blank check comports with Article I, Section 9, Clause 7 and, more broadly, the constitutional scheme of separate powers that serve to check and balance each other.

The complication is that Congress issued this blank check, and in theory it can terminate the privilege at any time. This generates two alternative possible interpretations: Section 881 might be deemed either an exercise of the congressional appropriations power, ${ }^{191}$ or an unconstitutional transfer of this power to

penditure or obligation; or involve [the] government in a contract or obligation for the payment of money before an appropriation is made unless authorized by law.").

${ }^{188}$ According to the GAO, "The prohibition against augmentation is a corollary of the separation-of-powers doctrine. ... Restated, the objective of the theory against augmentation of appropriated funds is to prevent a government agency from undercutting the congressional power of the purse by circuitously exceeding the amount Congress has appropriated for that activity." GAO, Principles of Federal Appropriations Law 5-62 (GAO 1982). Statutory counterparts to this doctrine include Pub I No 97-258, 96 Stat 923 (1982), codified at 31 USC $\S 1342$ (1994) (prohibiting employees of the government from accepting voluntary services for the government except in defined emergencies), and Pub L No 87-849, 76 Stat 1125 (1962), codified at 18 USC \& 209 (1994) (barring supplementation of government salaries with third-party funds).

${ }^{199}$ Supreme Court cases articulating this principle include Cincinnati Soap Co $v$ United States, 301 US 308, 321 (1937); Bradley v United States, 98 US 104, 112-13 (1878); Knote $v$ United States, 95 US 149, 154 (1877). According to the GAO, "the effect of 31 U.S.C. $\S 484$ is to ensure that the executive branch remains dependent on the congressional appropriations process .... [ [It] emerges as another element in the statutory pattern by which Congress retains control of the public purse under the separation-of-powers doctrine." GAO, Principles of Federal Appropriations Law at 5-65 (cited in note 188).

${ }^{100} 21$ USC $\S 881(\mathrm{e})(2)(\mathrm{B}) ; 28$ USC $\S 524(\mathrm{c})(1)$.

${ }^{191}$ That is, it could be an exercise of the appropriations power either directly or through a constitutional delegation to the Department of Justice. For reasons that will become clear in the balance of this section, the issuance of this kind of blank check can hardly be considered a direct appropriation because the agency gets to determine the size of its 
the executive branch. Obviously executive agencies must exercise legislatively delegated power, but there must be limits of degree or the organizing principle of the constitutional structure, the separation of powers, could be lawfully destroyed. ${ }^{192}$

In theory, the nondelegation doctrine is designed to discern this limit. The doctrine recognizes that legislative delegations are sometimes necessary because administrative agencies are better able to provide expertise, or the expeditious and flexible responses that may be required to regulate an area adequately. But to ensure that the legislative power remains with Congress, and that lawmaking does not devolve into the promulgation of ad hoc rules by unelected administrators, the doctrine requires that agency action be tethered to the legislature's defined ends. ${ }^{193}$ To accomplish this, a statute delegating congressional power must provide "intelligible principles" sufficient to channel agency discretion and provide a basis for a judicial review of that discretion. ${ }^{194}$ In the 1930s, the Supreme Court struck down a series of legislative delegations unaccompanied by such guiding standards. ${ }^{195}$ But although the Supreme Court subsequently invoked the doctrine, and sometimes construed statutory delegations narrowly in order to comply with its requirements, ${ }^{196}$ the Court did

budget. It is rather a delegation, and because it is a delegation of basic legislative power, an unconstitutional one. See text accompanying notes 205-23.

${ }^{192}$ See Mistretta $v$ United States, 488 US 361, 415 (1989) (Scalia dissenting) ("[T]he basic policy decisions governing society are to be made by the Legislature. Our Members of Congress could not, even if they wished, vote all power to the President and adjourn sine die."). Article I of the Constitution, which provides that "all legislative powers herein granted shall be vested in a Congress," prohibits the transfer of this power.

${ }^{193}$ See also Industrial Union Department, AFL-CIO $v$ American Petroleum Institute, 448 US 607, 685 (1980) (Rehnquist concurring) (The nondelegation doctrine is designed to ensure "that important choices of social policy are made by Congress ....").

${ }^{14}$ See id at 685-86, relying in part on J. W. Hampton, Jr. \& Co v United States, 276 US 394, 409 (1928), and Panama Refining Co v Ryan, 293 US 388, 430 (1935).

${ }^{155}$ See Carter v Carter Coal Co, 298 US 238, 289-97 (1936) (striking down a delegation of legislative authority to price-setting boards elected by coal producers); A.L.A. Schechter Poultry Corp $v$ United States, 295 US 495, 537-42 (1935) (finding the National Industrial Recovery Act unconstitutional in delegating to the President broad, standardless authority to establish codes of fair competition); Panama Refining, 293 US at 430-32 (striking down standardless statute granting the President discretionary power to prohibit interstate transportation of hot oil).

${ }^{196}$ National Cable Television Association, Inc $v$ United States, 415 US 336, 341-44 (1974) (citing Schechter, and narrowing the criteria enacted to govern the Federal Communications Commission ("FCC") in order to avoid an unconstitutional delegation of the power to tax); Industrial Union, 448 US at 645-46 (narrowing the discretion of the Secretary of Labor in promulgating Occupational Safety and Health Administration ("OSHA") standards to avoid unconstitutional delegation). 
not again find a delegation of legislative power unconstitutional for almost half of a century.

Scholars came to regard the idea of an unconstitutional legislative delegation as something of an oxymoron, but in the 1980s and 1990s, the nondelegation doctrine has been showing new signs of life. In The Benzene Case, ${ }^{197}$ an occupational health and safety standard promulgated by the Secretary of Labor was struck down as exceeding the executive's lawfully delegated authority. ${ }^{198}$ Two years later in INS $v$ Chadha, ${ }^{199}$ the Court overturned a delegation of legislative power to one House, finding it offended both the Presentment Clause and the bicameral structure of Article I. In 1995, the Eighth Circuit applied the nondelegation doctrine to overturn a statute authorizing the Secretary of the Interior to acquire land in trust for Indian tribes; it found that the standardless delegation created "an agency fiefdom whose boundaries were never established by Congress . . . . It is hard to imagine a program more at odds with separation of powers principles." 200 This past April, the District Court for the District of Columbia declared the Line Item Veto Act unconstitutional because Congress had ceded nondelegable, basic legislative functions to the President. ${ }^{201} \mathrm{~A}$ divided Supreme Court reversed

${ }^{197}$ Industrial Union Department, AFL/C1O v American Petroleum Institute, 448 US 607 (1980).

${ }^{298}$ Id at 652-62. The plurality opinion construed the Secretary's delegated authority narrowly to avoid unconstitutionality, placing the challenged regulation beyond the legislative delegation, while Justice Rehnquist found the statute itself an unconstitutional delegation of legislative power. Id at 685-88 (Rehnquist concurring). See also American Textile Manufacturer's Institute, Inc v Donovan, 452 US 490, 545-48 (1981) (Rehnquist dissenting) (dissenting on grounds that the OSHA standard was promulgated pursuant to an unconstitutional statute that delegated lawmaking power).

${ }^{199} 462$ US 919, 944-59 (1983).

${ }^{200}$ South Dakota v United States Department of Interior, 69 F3d 878, 885 (8th Cir 1995). Following this decision, the Government changed its position and promulgated a procedure for judicial review of the Secretary's decisions; a preamble to the regulation conceded that the Secretary was precluded from taking the land at issue in the Eighth Circuit case. The Supreme Court then granted the government's petition for certiorari, vacated the judgment, and remanded the case to the Court of Appeals with instructions to remand the case to the Secretary to reconsider his administrative decision. Deptartment of the Interior $v$ South Dakota, $117 \mathrm{~S} \mathrm{Ct} \mathrm{286,286-87} \mathrm{(1996).} \mathrm{Justice} \mathrm{Scalia,} \mathrm{joined} \mathrm{by} \mathrm{Justices}$ O'Connor and Thomas, dissented, arguing that to grant certiorari, vacate, and remand because "the Government, having lost below, wishes to try out a new legal position" was unfair. Id at 287.

${ }^{201}$ Byrd $v$ Raines, 956 F Supp 25, 33 (D DC 1997) ("[E]ven if Congress may sometimes delegate authority to impound funds, it may not confer the power permanently to rescind an appropriation or tax benefit that has become the law of the United States. That power is possessed by Congress alone, and, according to the Framers' careful design, may not be delegated at all."). The Line Item Veto Act, Pub L No 104-130, 110 Stat 1200 (1996), codified at 2 USCA $\S \S 691$ et seq (West 1997), allows the President to sign a bill into law and 
this decision three months later, holding that because the President had yet to exercise the line item veto, the plaintiffs lacked the injury necessary for standing to sue. ${ }^{202}$ The Court's ultimate decision on the merits, briefly delayed but inevitable, will provide at least some clues to its present thinking on the nondelegation issue. At this point it appears clear that the pendulum is gaining momentum in this new direction as Justices Rehnquist and Scalia ${ }^{203}$ along with numerous constitutional scholars, ${ }^{204}$ argue for a more vigorous application of the nondelegation doctrine.

If some delegations of legislative power are constitutionally suspect, giving law enforcement agencies the opportunity to set the size of their own budgets through police seizures must be one of them. By issuing this blank check, Congress has alienated the vital legislative function assigned to it by the Appropriations Clause: specifying the size and nature of the government's activities. To see this, one must recognize that an appropriation is not simply a procedural mechanism by which funds are released, but a substantive determination by the legislature of the relative worth of the program it funds. This understanding of the appropriations process-as a budgetary mechanism by which Congress shapes the activities of the federal government-has prevailed from the Constitution's inception to the present day. ${ }^{205}$ To consti-

then "cancel" any dollar amount of discretionary budget authority, any item of new direct spending, and any limited tax benefit. 2 USCA \& 691(a). Cancellation would take effect unless Congress reenacted a canceled item within thirty days of Presidential notification. 2 USCA § 691d.

${ }^{202}$ Raines $v$ Byrd, 117 S Ct 2312, 2322 (1997). Seven Justices refused to address the merits because the President had not yet exercised the veto. (President Clinton did so for the first time on August 11, 1997.) Justices Stevens and Breyer dissented separately, each finding the threat of a veto sufficient to restructure the relationship between the branches. Id at 2325-29. Justice Stevens, the only Justice to reveal explicitly his view on the merits, noted that he would find the law unconstitutional. Id at 2325 (Stevens dissenting).

${ }^{203}$ See Industrial Union, 448 US at 685-88 (Rehnquist concurring); Mistretta, 488 US at 416-27 (Scalia dissenting).

${ }^{204}$ See, for example, David Schoenbrod, The Delegation Doctrine: Could the Court Give it Substance?, 83 Mich L Rev 1223, 1283-90 (1985); Peter H. Aranson, Ernest Gellhorn, and Glen O. Robinson, $A$ Theory of Legislative Delegation, 68 Cornell L Rev 1, 63-67 (1982); John Ely, Democracy and Distrust 132-34 (Harvard 1980); Paul Gewirtz, The Courts, Congress, and Executive Policy-Making: Notes on Three Doctrines, $40 \mathrm{~L}$ \& Contemp Probs 46, 49-65 (Summer 1976); Carl McGowan, Congress, Court, and Control of Delegated Power, 77 Colum L Rev 1119, 1127-30 (1977).

${ }^{205}$ See, for example, Alexander Hamilton, Explanation (Nov 11, 1795), in Henry Cabot Lodge, ed, 8 The Works of Alexander Hamilton 122, 128 (Putnam 1885) ("N]o money can be expended, but for an object, to an extent, and out of a fund, which the laws have prescribed."); Louis Fisher, How Tightly Can Congress Draw The Purse Strings?, 83 Am J IntI L 758, 761 (1989) ("The Framers were familiar with efforts by English kings to rely on extra-parliamentary sources of revenue for their military expeditions and other activities. ... 
tutional scholar Kate Stith, one consequence is that the appropriations function imposes

an obligation on Congress itself. Congress has not only the power but also the duty to exercise legislative control over federal expenditures. ... In determining whether a grant of spending authority is a constitutional appropriation ... [w] hat matters is whether Congress in fact determines how much funding for a government activity is "appropriate.

This is precisely what Congress did not do when it enabled law enforcement agencies to fund themselves with whatever assets they might lawfully seize. As former Attorney General Richard Thornburgh has noted, "it's now possible for a drug dealer to serve time in a forfeiture-financed prison after being arrested by agents driving a forfeiture-provided automobile while working in a forfeiture-funded sting operation. ${ }^{\text {"207 }}$ In other words, law enforcement activities and resources are now unconstrained by any legislative determination of an appropriate budgetary level. This wholly thwarts Section 9's function as defined by the Supreme Court, which is "to assure that public funds will be spent according to the letter of the difficult judgments reached by Congress as

The rise of democratic government is directly related to legislative control over all expenditures."); Applicability of the Antideficiency Act Upon a Lapse in an Agency's Appropriation, 43 Op Atty Gen 224, 229 (1980) (stating Congress is required to determine the purposes and amounts of government expenditures); Kate Stith, Congress' Power of the Purse, 97 Yale L J 1343, 1352 (1988) (Appropriations constitute "legislative specifications of the powers, activities, and purposes-what we may call, simply, 'objects'-for which appropriated funds may be used."). Stith provides a comprehensive analysis of Congress' obligations in exercising its appropriations power. See also 31 USC § 1301(a) (1994) (Appropriations "shall be applied only to the objects for which the appropriations were made except as otherwise provided by law."). For an argument opposing this interpretation of the constitutional role of the appropriations process, see J. Gregory Sidak, The President's Power of the Purse, 1989 Duke L J 1162, 1185-88.

${ }^{206}$ Stith, 97 Yale L J at 1345-46 (cited in note 205). Stith maintains that because Article I, Section 8 enumerates Congress's powers, the Appropriations Clause in Section 9 does not grant power but rather "affirmatively obligates Congress to exercise a power already in its possession." Id at 1348. "Congress abdicates, rather than exercises, its power of the purse if it creates permanent or other open-ended spending authority that effectively escapes periodic legislative review and limitation." Id at 1345. Stith's analysis builds on her conception of the appropriations process as effecting two constitutionally mandated principles, which she calls the Principles of the Public Fisc and of Appropriations Control. The former is the principle that all monies received from whatever source by any part of the government are public funds. The Principle of Appropriations Control prohibits expenditure of any public money without legislative authorization. Id at 1345.

${ }^{207}$ Kelley Shannon, Seized drug money to be used for prisons, Houston Chron 12 (Sept 28,1989 ). 
to the common good and not according to the individual favor of Government agents. ${ }^{\text {2008 }}$

Our claim here is not that the Appropriations Clause requires Congress to specify a definite budgetary figure for executive agencies, or to do so yearly. As Stith argues, Congress may permanently authorize the expenditure of an indefinite sum to be fixed by later events ${ }^{209}$ (such as the sum necessary to finance the national debt, ${ }^{210}$ entitlement obligations, ${ }^{211}$ or contract obligations incurred by an agency pursuant to congressional authorization ${ }^{212}$ ) so long as it reflects a decision by Congress that the formula will result in the appropriate degree of funding and, therefore, agency activity. ${ }^{213}$ This could be the case even if Congress has authorized an agency to collect fees and utilize them for its operating budget, as when it decides a government service should be provided in proportion to the market's demand for it. (Consumer-generated revenue retained by the Postal Service, Amtrak, the Park Service, and the Securities and Exchange Commission are examples. ${ }^{214}$ ) There is a constitutional chasm, however, between a con-

${ }^{208}$ OPM v Richmond, 496 US 414, 428 (1990). The Court described this function as Section 9's "fundamental and comprehensive purpose." Id at 427. In another legislative delegation case, this one involving the Presentment Clauses, the Court observed that "the purposes underlying the Presentment Clauses ... . [must] guide our resolution [of the question whether a given procedure is constitutional]." Chadha, 462 US at 946.

${ }^{200}$ See Stith, 97 Yale L Rev at 1378-83 (cited in note 205). A permanent appropriation "does not require repeated action by the Congress to authorize its use." GAO, Principles of Federal Appropriations Law at 2-5 (cited in note 188).

${ }^{210}$ See Pub L No 97-258, 96 Stat 945 (1982), codified at 31 USC § 3123 (1994).

${ }^{211}$ For example, a standing appropriation for Social Security payments was codified at 42 USC §§ 401-23 (1994).

${ }^{212}$ The Anti-Deficiency Act establishes an exception for agencies to incur an obligation in advance of an appropriation if "authorized by law." 31 USC $\S 1341(a)(1)(B)$ (1994). Of course, a statute authorizing such advance expenditures must also comport with the constitutional requirements of the Appropriations Clause.

${ }^{213}$ Stith, 97 Yale L J at 1382-83 (cited in note 205). Stith regards the underlying substantive legislation establishing the entitlement, or authorizing the government to incur an obligation, as the "real 'Appropriations' for constitutional purposes." Id at 1382.

When Congress decides the substantive contours of the backdoor spending program, it decides, to a large extent, the proper funding level of the program. . . . In each of these instances, the form of the actual legislative permission to draw funds from the Treasury is largely irrelevant, because the government's monetary obligation is based on previous legislative action. ... . [Such backdoor] spending is consistent with the constitutional norm requiring Congress to control the public fisc as long as Congress clearly defines the activity being funded, provides a time limitation on the spending program, implicitly or explicitly decides the total amount of spending authority, and undertakes periodic legislative review.

Id at $1380,1382-83$.

${ }^{214}$ The Miscellaneous Receipts Act requires all sums received by the government to be deposited in the Treasury, 31 USC $\S 3302(\mathrm{~b})$ (1994), but Congress has legislated excep- 
gressional appropriation deliberately designed to size an agency according to market demand and a law effectively allowing a law enforcement agency to decide for itself what its size and resources will be. In the latter case, Congress has shed its obligation to set the purposes and amounts of government expenditures, transferring this legislative policy decision to self-interested administrators in the executive branch. ${ }^{215}$ That the executive branch has used the asset retention law to supplement its federal law enforcement budget by billions of dollars, ${ }^{216}$ in an area substantially immune to congressional oversight except through exercise of the appropriations power, ${ }^{217}$ underscores the importance of returning this power to Congress.

Measured against the kinds of congressional delegations of power that have been upheld in the past, the asset retention scheme is extreme, and outside any constitutional rationale.

tions to this requirement, allowing certain agencies to establish revolving funds or retain fees or gifts. A revolving fund is designed for government enterprises designed to be at least partly self-sustaining, such as the Postal Service, the Federal Deposit Insurance Corporation, a government loan program, or a turnpike authority. The activity of the agency is at least partly sustained by the income it produces. Apart from such dedicated revolving funds, Congress has also authorized certain agencies to retain the user fees it charges, see, for example, Independent Offices Appropriation Act of 1952, Act of Aug 31, 1951,65 Stat 290, codified at 31 USC $\$ 9701$ (1994), and National Cable, 415 US at 34041 , or retain certain gifts, see, for example, Mutual Educational and Cultural Exchange Act of 1961, Pub L No 87-256, 75 Stat 527, codified at 22 USC $\S 2455(f)$ (1994) (providing authority to receive and utilize conditional gifts). See also Stith, 97 Yale L J at 1365-81 (cited in note 205) (detailing exceptions to the dual requirements that all funds collected be deposited in the Treasury and that all spending be pursuant to a specific appropriation).

${ }^{215}$ For related reasons, the Supreme Court construed the Independent Offices Appropriation Act of 1952 to permit the FCC to collect fees based only on the value of its services to the recipient, not on the public interest that might be served by the collection. National Cable, 415 US at 341-43. The statute "if read literally, carries an agency far from its customary orbit and puts it in search of revenue in the manner of an Appropriations Committee of the House." Id at 341 (construing the statute to avoid abridging Art I, § 8, cl 1, vesting Congress with the "power to lay and collect taxes."). Similarly, one important factor in upholding the delegation at issue in Skinner $v$ Mid-America Pipeline Co, 490 US 212 (1989), was that Congress limited the aggregate amount of pipeline user fees the agency could charge, and also specified that the fees be set according to "volume-miles, miles, or revenue." Id at 219-20.

${ }^{216}$ See note 102.

${ }^{217}$ See Stith, 97 Yale L J at 1383-84 (cited in note 205). Stith argues that budgetary oversight is especially important in areas where the Executive has broad discretion in defining government policy, and points to federal prosecutions as an example. In this area, "the 'object' specifications in appropriations are necessarily broad ... . [and] the Executive bears primary responsibility for determining how and where to assert a federal presence. If Congress creates spending authority which is open-ended with respect to amount and duration .... it effectively concedes any role in defining and constraining executive-that is, governmental-action." Id. 
None of the reasons that courts have used to justify a delegation $^{218}$ applies to a law that allows the Department of Justice to write its own budget. And even were a delegation of the appropriations function warranted, here it is unaccompanied by any "intelligible principles" to guide agency discretion, or any other means of legislative control over the size and scope of the agency's budget: the asset retention law is devoid of any spending ceilings, time limits, funding formulas, meaningful reporting requirements, or congressional review procedures. ${ }^{219}$

These comparisons, however, are largely beside the point. An inquiry focused on whether the delegation is "excessive" or whether the standards are "inadequate" is misdirected when Congress has transferred a basic legislative function that cannot be delegated at all. As the courts have recognized, Congress cannot delegate its basic legislative powers because doing so would dismantle the essential constitutional structure of balanced, coequal branches. ${ }^{220}$ In this case, by ceding to the executive part of its unquestionably exclusive appropriations power, ${ }^{221}$ Congress has abandoned what Edward Corwin described as "the most important single curb in the Constitution on Presidential power. ${ }^{m 22}$

${ }^{213}$ Legislative delegations have been found appropriate when necessary to avoid enmeshing legislators in "the sort of intricate, labor intensive task" better suited to administrators, Mistretta, 488 US at 379 (upholding delegation of sentencing terms to the U.S. Sentencing Commission); or because the legislature would necessarily speak in terms too general to suffice, see, for example, American Power and Light Co $v$ SEC, 329 US 104, 105 (1946); or to provide more expeditious or flexible responses than Congress can manage, see, for example, Zemel $v$ Rusk, 381 US 1,17 (1965) (dealing with foreign affairs expediencies), and United States $v$ Grimaud, 220 US 506, 516 (1911) (concerning Agriculture Department regulations); or to utilize the kind of expertise that a specialized agency can develop and provide, see Mistretta, 488 US at 368 .

${ }^{219}$ The asset retention law is a good illustration of Stith's warning that "Congress renders meaningless the Principles of the Public Fisc and of Appropriations Control if it creates spending authority without amount or time limitations and fails to subject such authority to periodic legislative review." Stith, 97 Yale L J at 1383 (cited in note 205).

${ }^{20}$ See Panama Refining, 293 US at 421 ("Congress manifestly is not permitted to abdicate, or to transfer to others, the essential legislative functions with which it is thus vested."); Field $v$ Clark, 143 US 649, 692 (1892) ("That Congress cannot delegate legislative power to the President is a principle universally recognized as vital to the integrity and maintenance of the system of government ordained by the Constitution."); Byrd, $956 \mathrm{~F}$ Supp at 36 ("Before the question of a delegation's excessiveness ever arises . . . a court must be convinced that Congress did not attempt to alienate one of its basic functions.").

${ }^{221}$ See Michael J. Glennon, Strengthening the War Powers Resolution: The Case for Purse-Strings Restrictions, 60 Minn L Rev 1, 32 (1975).

${ }^{222}$ Edward S. Corwin, The Constitution and What it Means Today 134 (Princeton 14th ed 1978). See also Federalist 58 (Madison), in Jacob E. Cooke, ed, The Federalist 391, 394 (Wesleyan 1961) (characterizing the appropriations power as "the most compleat and effectual weapon with which any constitution can arm the immediate representatives of the people"); Alan L. Feld, Shutting Down the Government, 69 BU L Rev 971, 989 (1989) (de- 
The prospect of a self-financing law enforcement branch, largely able to set its own agenda and accountable to no one, presents the kind of dangers one of the framers, George Mason, must have had in mind when he warned that "[ $t]$ he purse \& the sword ought never to get into the same hands (whether legislative or executive). ${ }^{\text {m223 }}$

\section{B. Policy Objections}

Suppose we are wrong, and the Appropriations Clause poses no constitutional obstacle to law enforcement self-funding. Should Congress continue to authorize potentially independent law enforcement agencies that need not justify their activities to the taxpayers, their elected representatives, or any budgetary authority? To us it is self-evident that agencies privileged to arrest, seize property, and use even deadly force pose special risks that warrant greater safeguards and scrutiny, not less. For this reason, the forfeiture self-funding mechanism poses a double threat: the risks of abuse that flow from this financial incentive are compounded because no one is watching.

We need not reiterate here the kinds of abuses and policy problems discussed in Section II. It is useful, however, to document the remarkable lack of accountability drug law enforcement now enjoys. The asset retention law did not create this problem, or the uncontrolled agencies and rogue officers that are endemic to drug law enforcement, but it did add a great deal of fuel to the fire. To illustrate this, we detail some of the activities of the mul-

scribing the power of the purse as "the most viable limitation that legislation and the Constitution places on executive discretion"). See also Chadha, 462 US at 957 (Article Is enduring checks "protect the people from the improvident exercise of power....").

${ }^{23}$ Max Farrand, ed, 1 The Records Of The Federal Convention Of 1787 139-40 (Yale 1937). The Iran-Contra scandal was a recent and egregious illustration of this danger. There the executive branch usurped the appropriations power by having Oliver North obtain funds through secret arms sales to Iran that were then channeled directly to the Nicaraguan Contras. See generally House and Senate Committees Investigating the IranContra Affair, Iran Contra Investigation Report, HR Rep No 100-433, S Rep No 100-216, 100th Cong, 1st Sess (1987). As the report noted, "[t]he Constitution contemplates that the Government will conduct its affairs only with funds appropriated by Congress." Id at 411 . "[U]nder the view of North and Poindexter, a President whose appropriation requests were rejected by Congress could raise money from private sources . . . [even for] domestic programs. That is the path to dictatorship." Id at 390. Of course, the forfeiture case is distinguishable in that Congress has itself authorized the executive to bypass the appropriations process. How important is this distinction? To answer that question, we would do well to ask another: if Congress had been told about Oliver North in advance, and had passed a law institutionalizing a secret, self-financing "off-the-shelf" White House operation whose scope and activities would be determined by the entrepreneurial skills of its agents, would the constitutional order have been any less threatened? 
tijurisdictional drug task forces that have proliferated in the past decade. They reveal that while the forfeiture and drug prohibition laws have not solved America's drug problem, enforcing them has created a significant police problem.

Most multijurisdictional drug task forces are offspring of the Byrne program, but once created they may achieve an independent life of their own. The block grant concept minimizes congressional oversight, ${ }^{224}$ and federal participation in the Byrne-funded task forces is uncommon. ${ }^{225}$ In theory, a multijurisdictional drug task force is tied to state budgetary allocations and oversight, as the law requires states to match the federal grant with 25 percent state funding. ${ }^{26}$ But states may satisfy this requirement with forfeiture money seized by the task force, ${ }^{227}$ thereby eliminating any need for the task force to justify its activities to a state or local authority. Indeed, if the forfeiture intake is high enough, federal Byrne grant money can also be phased out, and the task force may become a self-financing, self-perpetuating, and independent entity. ${ }^{228}$ Between 1988 and 1992, Byrne-grant-funded multijurisdictional task forces seized over $\$ 1$ billion in assets. ${ }^{229}$

Multijurisdictional drug task forces may elude meaningful oversight for two additional reasons. First, they are not tied to any local constituency. The combination of state, local, and in some cases, federal agencies divides responsibility, encourages passing the buck, and leaves no particular elected government in control. It also promotes jurisdictional game playing: if local police do not like their state's asset distribution scheme, or if state law would bar a seizure, federal involvement allows them to nullify the state's efforts to regulate their activity. ${ }^{230}$ Second, drug

${ }^{224}$ See Departments of Commerce, Justice and State, Judiciary and Related Agencies Appropriations for 1996, Hearings before Subcommittee of the House Committee on Appropriations, 104th Cong, 1st Sess 489-90 (Mar 28, 1995) (statement of Joseph E. Brann, Director of the Office of Community Oriented Policing Services), where Brann testified about the lack of oversight, and that "block-granting law enforcement money led to waste, fraud, and abuse, and not a commensurate reduction in crime."

${ }^{225}$ In a nationwide survey of task force commanders, 97 percent reported that local law enforcement agencies were components of their task forces, but just over 25 percent included federal law enforcement agencies. Coldren, et al, Multijurisdictional Drug Task Force Operations at 9 (cited in note 33).

${ }^{20}$ See Pub L No 90-351, 102 Stat 4333 (1988), codified at 42 USC § 3754(a) (1994).

${ }^{2 m} 42$ USC § 3754(e) (1994).

${ }^{223}$ See JRSA, Five-Year Review at 9 (cited in note 1).

${ }^{20}$ Id at 10 . This amount includes only those seizures by task forces receiving federal Byrne grants. It does not include assets seized by the DEA or other task forces, or seizures under state forfeiture laws.

${ }^{230}$ See, for example, the situation described in United States $v$ Winston-Salem/Forsyth County Board of Education, 902 F2d 267, 269 (4th Cir 1990), in which local police seized 
task forces are engaged in the enforcement of so-called victimless crimes, where there is no aggrieved individual to inform the police what happened. Consequently, task forces must operate surreptitiously at the margins of legitimate activity, utilizing undercover police, spies, informants, stings, and entrapment. Such secret and deceptive activities further complicate any effort to make task forces accountable, while simultaneously inviting corruption.

How have task forces exercised their freedom? Of course, one obstacle to answering this question is that the very absence of accountability makes it difficult to monitor what the task forces do. 231 Their actual operations are inevitably murky. The best, though flawed, evidence we have comes from the task force commanders themselves via a 1993 nationwide survey. ${ }^{232}$ Prefaced with a disclaimer that "little is known about the range of tactics being employed by task forces, how frequently they are used, or how often task forces change their tactical approaches to enforcement, ${ }^{2233}$ the survey nevertheless conveys some rudimentary knowledge of task force activities. It reports that tactics commonly used include buy-busts, reverse stings, street sweeps, undercover operations, and confidential informants. ${ }^{234}$ In addition, slightly over 30 percent of task force commanders said they were using novel tactics, such as:

enrolling youthful-looking officers to perform undercover work in high schools, using college students as operatives in universities ... and placing undercover officers in jail with known drug users and dealers ....,

over $\$ 10,000$, temporarily turned it over to the DEA for federal adoption, and then received most of it back for their own use. Although the state constitution required the funds to be used for public school maintenance, and prohibited the transfer to the DEA, the court found that the federal government could adopt a seizure even when the person seizing the property was prohibited from seizing or transferring it under state law. Id at 27172. In other words, the federal route allowed state police to directly profit from their own lawlessness.

${ }^{231}$ Three scholars who attempted to study the Byrne program found that its administrative complexity "makes it difficult, and perhaps impossible, to assess the program's impact on violent crime, drug trafficking or other specific crime prevention goals on a national scale." Editorial, Should Washington Fight Crime?, Inv Bus Daily A2 (Dec 13, 1995), quoting report by John J. Dilulio, Steven K. Smith, and Aaron J. Saiger.

${ }^{222}$ The survey obtained information from 528 task force commanders across the country. Coldren, et al, Multijurisdictional Drug Task Force Operations at i (cited in note 33).

${ }^{223}$ Id at 16 . The report also states, "The impact of MDTFs on the availability of drugs, drug trafficking, drug abuse or other indicators has been difficult to determine, but is generally presumed to be positive by those involved in task force operations." Id at 2.

${ }^{234}$ Id at 17. 
[targeting] public events such as sporting matches and concerts to identify and arrest drug offenders ....,

operating hotel/motel programs where narcotics officers interact regularly with hotel/motel personnel to detect drug activity and identify suspects ....,

[operating] business fronts, often in high drug activity areas, to purchase drugs and identify drug dealers. Fronts include a travel agency, gamerooms, pool halls, a car dealership, bars, and a chemical company...,

[establishing] drug hotlines with toll free, 24 hour numbers so citizens can call in anonymous tips on drug dealers and drug activity. ... Some pay rewards for useable information. ...

The few task force commanders who reported intercepting suspects' garbage indicated they thought these efforts were quite successful in producing evidence leading to search warrants. ... [Less frequently reported tactics included] trading food stamps for drugs enabling MDTFs to prosecute through the federal system. ${ }^{235}$

With little oversight and a lot of money, task forces might be expected to develop just such aggressively unconventional techniques to prosecute the Drug War. Yet despite these efforts, and the attendant prodigious seizures of assets and drugs (primarily cannabis ${ }^{236}$ ), a five-year review of task forces concluded that "[i]t is not clear . . . whether task forces have been an effective deterrent to either the street- or mid-level dealers. ${ }^{237}$

Not surprisingly, the commanders' survey did not reveal any management or corruption problems. But it is increasingly apparent that task forces are plagued by these problems. One example came to light in 1996 , when almost $\$ 66,000$ was discovered hidden in the former headquarters of the Western Area Narcotics Task Force ("WANT") in Paducah, Kentucky. ${ }^{238}$ An inquiry fol-

\footnotetext{
${ }^{235} \mathrm{Id}$ at 18-19.

${ }^{256}$ The total kilograms of cannabis (marijuana and hashish) removed from circulation exceeded the kilograms of cocaine removed by a ratio of twenty-six to one. JRSA, FiveYear Review at 8 (cited in note 1 ).

${ }^{237}$ Id at 10.

${ }^{238}$ This investigation has been closely reported by Bill Bartleman, David Fraser, and Robin Divine in The Paducah Sun since January 1996.

WANT was established in 1988 with Byrne-grant funding. Although twenty law en-
} 
lowed to determine where the money came from and what to do with it. ${ }^{239}$ Investigators learned that the task force had seized large amounts of money and then dispensed it freely, unconstrained by audits, reporting requirements, or the task force's mission. ${ }^{240}$ This problem is endemic to forfeiture beneficiaries, from the Department of Justice on down. ${ }^{241}$

The investigation shed light on the routine operations of WANT, and probably many others as well. Both seizures and expenditures were largely lawless. Like other task forces, ${ }^{242}$ WANT made asset seizures a priority, mandating expected forfeiture growth rates. ${ }^{243}$ But WANT met its quotas with much more zeal

forcement agencies were nominally members, it was staffed and run by members of the Paducah Police Department, and given a separate office in the police building's basement. The event triggering media attention was the removal of WANT from these separate headquarters to an office within the Paducah Police Department, in response to criticisms that WANT had been hindering investigations by other law enforcement agencies. See Associated Press, State Finds Room for Improvement in Drug Team, Louisville Courier J B1 (Sept 5, 1993); Robin Divine, Paducah overhauls drug investigation unit, Paducah Sun 1A (Feb 14, 1996); David Fraser, Police asked to investigate loss of evidence, Paducah Sun 1A (June 22, 1996).

${ }^{200}$ Authorities believe that the money is either evidence or property seized from drug dealers from hundreds of separate drug-related incidents. Editorial, Cash discovery raises questions, Paducah Sun 4A (Feb 27, 1996).

${ }^{210}$ The Paducah Sun editorialized:

The discovery of the money and the management breakdown it suggests are disturbing .... The developments provide further confirmation that WANT operated with far too much independence and far too little accountability. . . . [T] counting and supervisory backup are demanded; instead they were conspicuously lacking. The result, as we see, is a scramble by top city officials to explain how $\$ 50,000$ can suddenly show up in a municipal space.

Id.

${ }^{211}$ See, for example, Directive 87-1, Memorandum from Associate Attorney General Stephen S. Trott to all U.S. Attorneys, Seized Cash (Mar 13, 1987), in DOJ Asset Forfeiture Manual at B-477 (cited in note 62) ("The security, budgetary, and accounting problems caused by retention of large amounts of cash is causing great concern within the Department and the Congress."); Federal Government Financial Management, Hearing Before the Senate Committee on Governmental Affairs, 104th Cong, 1st Sess 54 (Dec 14, 1995) (statement of Charles Bowsher, Comptroller General) ("[A]udits found that Customs did not ... have adequate accountability over tons of illegal drugs and millions of dollars of cash and property seized or used in its enforcement efforts ....").

${ }^{242}$ See generally Coldren, et al, Multijurisdicitonal Drug Task Force Operations (cited in note 33). Seventy-eight percent of task force commanders rate seizing assets as a high priority. Id at 7 ("The most significant change lin task forces occurring since their inception] is in the number of task forces that now place a high priority on asset seizures and promoting awareness within the community compared to when the task forces began."). The most common change reported in the operation of task forces was seizing assets; ninety-nine percent of those who changed their emphases said they had increased emphasis on asset seizure. Id at exh 4.

${ }^{2 * 3}$ For example, WANT's 1995 application for federal grant money declared an objective of a 20 percent rise in asset seizures. David Fraser, WANT applications place burden 
than care. The police chief estimated that 60 percent of the money found in WANT headquarters will be returned to the owners because it was not properly seized. ${ }^{244}$ Often the seizures had no nexus to any drug transaction. Arrests were delayed for weeks and even months, at which point the police took whatever they found on or near the defendant at the time, despite the lack of connection between the seized property and the now-distant drug transaction. ${ }^{245}$ Some seizures were as small as eight cents. ${ }^{246}$ Another seizure of ninety-three cents showed "once again that the officers were taking whatever the suspects were carrying, even though by no stretch could pocket change . . . be construed to be drug money."247

The subsequent handling of seized assets was equally lawless. WANT refused to deposit money into a special account through the city's Finance Department. It maintained no system to record seizures, identify particular seized assets with their owner, or indicate what assets had been forfeited. ${ }^{248}$ Kentucky's asset distribution formula was disregarded, ${ }^{249}$ and the task force retained cash in vaults, boxes, bags, lockers, and envelopes. One can only speculate on how the money was used, but earlier reports had criticized WANT for improperly diverting its grant money to investigate non-drug activity and cover cost overruns, ${ }^{250}$ and diverting personnel and equipment to monitor elected officials and private citizens for what appeared to be vindictive reasons. ${ }^{251}$ The discovery of hidden cash provoked a major media scandal in Kentucky. But despite the predictions of some task force members that WANT's history would mark it for termina-

on Gorden, officer, Paducah Sun 1A, 18A (Mar 22, 1996).

${ }^{24}$ David Fraser, Some cash seizures wrong, Paducah Sun 1A, 12A (Mar 14, 1996).

${ }^{213}$ David Fraser and Bruce Gardner, WANT records emphasize deals of smaller scale, Paducah Sun 1A, 12A (Mar 16, 1996).

${ }^{246}$ David Fraser, More WANT money found, Paducah Sun 1A, 13A (Mar 13, 1996).

${ }^{217}$ Editorial, Police Woes: Lost evidence reflection on WANT, Paducah Sun 4A (June 21, 1996).

${ }^{218}$ A 1993 study conducted by the state's criminal justice agency, the Justice Cabinet, cited WANT for failing to establish adequate procedures for handling cash and storing evidence (as well as for misuse of equipment and resources, inadequate leadership, and lack of accountability). WANT Grant Program Monitoring-Final Report (Sept 2, 1993).

${ }^{219} \mathrm{Ky}$ Rev Ann Stat § 218A.435 (Michie 1995).

${ }^{250}$ See Bill Bartleman, Hoover: Plan about WANT not followed, Paducah Sun 1A, 8A (Mar 5, 1996). Byrne grant money may be spent for carefully delineated items. It may not be used to pay for budgeted items or cost overruns. See GAO, War on Drugs, Federal Assistance to State and Local Drug Enforcement at 20-21 (cited in note 33).

${ }^{251}$ See Bartleman, Paducah Sun at $1 \mathrm{~A}$. 
tion, WANT survived, changed its name, and prospered with increased funding. ${ }^{252}$

The new forfeiture laws have promoted these police abuses and, by abandoning budgetary oversight, helped insulate them from public scrutiny. Drug law enforcement does not need these additional problems. It is already plagued by a higher degree of lawlessness and corruption than any other area of law enforcement. ${ }^{253}$ Its reliance on informants and undercover work puts officers in intimate contact with criminals, money, and drugs, while simultaneously shielding their activities from public view. For dishonest officers, these circumstances are tantamount to a license to steal, deal drugs, plant evidence, or perjure themselves with impunity. ${ }^{254}$ Defendants are unlikely to benefit from com-

${ }^{252}$ Its 1996 federal grant was increased by almost $\$ 100,000$ over the previous year, to $\$ 312,368$, with local agencies contributing almost $\$ 150,000$. David Fraser, Drug team gets new grant, and new name, Paducah Sun 2A (July 3, 1996). Under new direction and with an increased staff and budget, the rechristened Jackson Purchase Area Drug Task Force is ready to resume fighting the war on drugs. Paducah's mayor remarked, "[T]hey gave us all we asked for .... I I don't know exactly what caused it to happen that way. . . . I think we will see new horizons open for the task force, larger scale operations." Id.

${ }^{25}$ See, for example, Mollen Commission Report at 15 (cited in note 163) ("Most serious police corruption today arises from the drug trade. ... [The] wide spectrum of drug-related corruption [ranges] from opportunistic thefts from street dealers, to carefully planned group assaults on drug locations, and long term partnerships with narcotics traffickers.").

${ }^{251} \mathrm{~A}$ former federal prosecutor says that in drug arrests "you almost always find cash. The problem has always been: How do you watch this process? . . It's a textbook scenario for corruption." Gerard O'Neill, Mitchell Zuckoff, and Dick Lehr, Corruption probe shakes up Boston police detective unit; The case of the disappearing money, Boston Globe Metro 1 (Feb 10, 1996). The comment pertained to a Boston police scandal, but similar corruption in drug law enforcement has been uncovered in numerous other cities. In New York, the Mollen Commission revealed widespread corruption in the 30th Precinct with more than thirty officers stealing drug money, and some selling the drugs they seized. Mollen Commission Report at 22-35 (cited in note 163). It also found pervasive police perjury designed to cover up illegal arrests and searches in drug cases. Id at 36-43. In Philadelphia, five officers in the 39th precinct were indicted and dozens of convictions overturned due to rampant criminal activity that included beating suspects, planting drugs, stealing drugs and money, selling drugs, falsifying official arrest reports to sanitize illegal arrests, and providing perjured testimony. According to The Philadelphia Inquirer, the officers worked "with virtual impunity ... . driven by the opportunity to steal money and drugs from street dealers and earn overtime pay for court appearances. . . . Because those officers admitted framing countless drug suspects, 42 people arrested since 1988 have had their cases dismissed. Hundreds of other convictions are being reviewed." Mark Bowden and Mark Fazlollah, Police Corruption Inquiry Widens: Up to 9 Officers in Elite Unit Implicated, Phil Inq AI (Aug 13, 1995). See also David Rudovsky, Why It Was Hands Off On the Police, Phil Inq A7 (Aug 8, 1995) (regarding the 39th District, "it now appears that well over a thousand persons were either arrested without cause, subjected to illegal searches and seizures, had money stolen and/or were physically abused by the police"); Joseph $D$. McNamara, Law Enforcement: Has the Drug War Created An Officer Liars' Club?, LA Times M1 (Feb 11, 1996) ('The message that politicians seem to be sending to the nation's police chiefs is that we understand police perjury is a part of the drug war."). 
plaining about police theft of their drugs or money, and otherwise honest officers who learn of police illegality confront intense institutional pressures not to report fellow officers. ${ }^{255}$ It may be that such problems are intractable, but there is no reason for state and federal governments to exacerbate them by relinquishing whatever controls and budgetary oversights they possess.

\section{REMEDIES AND PROSPECTS}

The logic of Supreme Court decisions leads to the conclusion that self-financing, potentially independent law enforcement agencies are constitutionally objectionable, on both due process and separation of powers grounds. But in each case the Supreme Court would have to take a step into territory that it has left relatively unexplored. Whether the present Supreme Court would do so is speculation at this point. Although most forfeiture law reform challenges have failed, the Court has recognized that forfeiture "can be devastating when used unjustly"256 and that "it makes sense to scrutinize governmental action more closely when the State stands to benefit. ${ }^{257}$ Some of the Justices are committed to strengthening property rights, ${ }^{258}$ or restricting legislative delegations to the executive ${ }^{259}$-legal values entirely at odds with the present forfeiture laws. Critics of the present system also may be heartened by the increasingly vocal concern expressed by observers across the political spectrum-from the American Civil Liberties Union ("ACLU") ${ }^{260}$ to Justice Thomas, ${ }^{261}$ and including the

${ }^{25 s}$ Since failure to report their colleagues would make these officers complicit anyway, it is often easier to join in the illegalities. An unwilling officer may even be coerced into joining the others by threats that he will be implicated whether or not he engages in corruption. See Mollen Commission Report at 20 (cited in note 163) ("[C]orrupt officers were typically protected by the silence of their fellow officers, and often the willful blindness of supervisors.").

${ }^{256}$ Caplin \& Drysdale, Chartered v United States, 491 US 617, 634 (1989).

${ }^{25}$ United States $v$ James Daniel Good Real Property, 510 US 43, 56 (1993), citing Harmelin v Michigan, 501 US 957, 979 n 9 (1991) (Scalia dissenting). In James Daniel Good, the Supreme Court required notice and a hearing before seizure of allegedly forfeitable real estate under 21 USC $\$ 881(a)(7) .510$ US at 62.

${ }^{25 s}$ See, for example, James Daniel Good, 510 US at 61 (Justice Kennedy writing for the Court, joined by Justices Blackmun, Stevens, Souter, and Ginsburg) ("Individual freedom finds tangible expression in property rights. At stake in this and many other forfeiture cases are the security and privacy of the home and those who take shelter within it.").

${ }^{239}$ See Section III.A.

${ }^{260}$ See Jan 10, 1994 Letter to President Clinton from a coalition led by the ACLU seeking a national commission to review the policies and practices of all federal law enforcement agencies, and criticizing, inter alia, the "inappropriate and disproportionate use of forfeiture proceedings to obtain financing for law enforcement equipment and activities." ACLU, News Release 4 (Jan 10, 1994). Other signers included the National Rifle As- 
former Associate Director of the Department of Justice's Asset Forfeiture Office ${ }^{262}$ - that forfeiture laws prompt some police and prosecutors to target assets rather than crime.

If the Supreme Court is unresponsive to constitutional claims regarding asset retention, there are other, less direct litigation strategies to limit the abusive application of Section 881. An important 1993 Supreme Court decision, Austin v United States, ${ }^{263}$ has the potential to do so, although whether this potential will be realized is not yet clear. In Austin, the Court held unanimously that civil forfeitures are subject to the Eighth Amendment's prohibition on excessive fines. ${ }^{264}$ This is an important limitation be-

sociation, the National Legal Aid and Defender Association, the Second Amendment Foundation, and the National Association of Criminal Defense Lawyers. Id at 2. For a report on this coalition, see Michael Hedges, Diverse Coalition Seeks Oversight of Federal Law Officers, Wash Times A3 (Jan 11, 1994).

${ }^{261}$ Justice Thomas cautions that forfeiture "[i]mproperly used . . . could become more like a roulette wheel employed to raise revenue from innocent but hapless owners whose property is unforeseeably misused, or a tool wielded to punish those who associate with criminals, than a component of a system of justice." Bennis, $116 \mathrm{~S} \mathrm{Ct}$ at 1003 (1996) (Thomas concurring). Although Justice Thomas consistently votes to uphold the government in forfeiture cases, he has expressed concern with the breadth of modern forfeiture law, suggesting that it may be time to "reevaluate our generally deferential approach to legislative judgments in this area of civil forfeiture." James Daniel Good, 510 US at 82 (Thomas concurring). Justice Thomas argues that property rights, and particularly rights to real property, are threatened by the government's aggressive use of broad forfeiture statutes like 21 USC $\S 881(a)(7)$, which he believes significantly differs in degree and in kind from its historical antecedents. He questions whether the fiction of guilty property can justify the "immense scope" of this statute. Id at 81-82.

${ }^{202}$ The former Associate Director, David Smith, writes that

a less obvious reason for the large number of conveyances seized by law enforcement agencies is the fact that forfeited conveyances are often placed into government service. Forfeiture of conveyances is a cheap way to provide the cars, vessels and planes that law enforcement agencies need. However, there is evidence that law enforcement priorities are being distorted by this system. There is also the danger that agents may pursue forfeitures overzealously in these circumstances.

Smith, Forfeiture Release 16 II 3.03 at 3-12 (cited in note 44), citing as one example, United States $v$ One 1976 Buick Skylark, 453 F Supp 639, 643 (D Colo 1978). As Smith also notes, drug seizures have a more significant impact on a trafficker's cost of doing business than asset forfeitures. "[L]arge quantities of drugs have a much greater cost to the owner than anything likely to be seized for forfeiture, although their value to the government is zero. Accordingly, it would be counterproductive for DEA and other federal agencies to devote more resources to asset forfeitures at the expense of drug seizures." Smith, Forfeiture II 1.02 at 1-25. See also United States $v$ That Certain Real Property Located at 632-636 Ninth Avenue, Calera, Alabama, 798 F Supp 1540, 1551 (N D Ala 1992) ("More and more courts are voicing frustration at what appears to be overreaching by the United States in the drug war, particularly in forfeiture cases where law enforcement agencies have a 'built-in' conflict of interest because they share in the product of the seizure.").

${ }^{205} 509$ US 602 (1993).

${ }^{204}$ Id at $621-22$. 
cause on its face, Section 881 would seem to allow forfeiture of any property, no matter how valuable, if it could be linked to even a minor drug violation. ${ }^{265}$ Civil forfeiture formerly was thought not to implicate the excessive fines provision because it was labeled civil. In Austin, however, the Court found that forfeiture constitutes punishment regardless of whether it is considered civil or criminal, and therefore is subject to the Eighth Amendment. ${ }^{266}$ Presumably the Austin holding will now provide recourse for a family whose home was seized because a teenage son had sold "nickel bags" in his bedroom. The Supreme Court, however, did not announce a test of excessiveness, leaving that task to lower courts. Which test ultimately prevails will determine whether the Eighth Amendment provides a meaningful constraint. ${ }^{267}$

${ }^{255}$ Controlled substances, raw materials, instrumentalities, containers, and conveyances tied to a drug violation may be forfeited pursuant to 21 USC $\$ 881$ (a), except that real estate may be forfeited only if it facilitated the commission of a drug crime punishable by imprisonment for more than one year. 21 USC $\$ 881(a)(7)$.

${ }^{256}$ The Court refused to define forfeiture as purely remedial and nonpunitive because there is no necessary correlation between the seized property and costs borne by the government or by society. Austin, 509 US at 621, citing United States $v$ Ward, 448 US 242, 254 (1980). See also United States $v$ Certain Real Property and Premises Known As 38 Whalers Cove, 954 F2d 29, 37 (2d Cir 1992) (To be solely remedial, a forfeiture cannot be disproportionately large, "placing full responsibility for the 'war on drugs' on the shoulders of every individual claimant."). Even before Austin, many lower court judges had questioned the constitutionality of grossly disproportional forfeitures under the Eighth Amendment's prohibition on excessive fines and cruel and unusual punishments. See, for example, Pratt and Petersen, 65 St John's L Rev at 669 (cited in note 27) (arguing that, "When an expensive automobile is forfeited on the strength of less than twenty-five grams of marijuana, one must swallow hard to maintain that the 'punishment' is proportionate to the 'crime' ....") (citations omitted), citing similar concerns in United States $v$ Property at 4492 S. Livonia Road, 889 F2d 1258, 1270 (2d Cir 1989).

${ }^{257}$ The Supreme Court will revisit the issue in 1998, having agreed to hear an appeal from a Ninth Circuit decision holding that forfeiture of $\$ 357,114$ in cash at Los Angeles International Airport from a man trying to smuggle it to Syria, in violation of a law prohibiting the undeclared export of more that $\$ 10,000$, was an excessive fine under the Eighth Amendment. United States v Bajakajian, 117 S Ct 1841 (1997). Although Justice Scalia proposed an "instrumentality test" that would measure excessiveness solely by examining the property's nexus to the offense without reference to its value, Austin, 509 US at 627-28 (Scalia concurring), the majority explicitly left the question open, id at 622. Several lower courts have insisted that a comparison between the gravity of the offense and the value of the property ( $a$ "proportionality test") must figure in the Eighth Amendment determination as well. One test, enunciated by a federal district court, would apply the following three-factor test to determine whether the Excessive Fines Clause is violated: "(i) the inherent gravity of the offense compared with the harshness of the penalty; (ii) whether the property was an integral part of the commission of the crime; and (iii) whether the criminal activity involving the defendant property was extensive in terms of time and/or spatial use." United States v Real Property Located at 6625 Zumirez Drive, Malibu, California, 845 F Supp 725, 732 (C D Cal 1994). It notes that the test considers both the culpability of the claimant and the property's relationship to the offense, id at 733 
Other more speculative litigation strategies are beyond the scope of this Article. We merely note that as forfeiture law and constitutional doctrine continue to develop, some possible challenges may be grounded in the ethical constraints that govern prosecutors, ${ }^{268}$ doctrinal limitations on "outrageous governmental

n 4, and concludes:

[T] government's potential for abusive use of the civil forfeiture statutes. The constitutional protection of the Excessive Fines Clause is especially important in the forfeiture context "where the Government has a direct pecuniary interest in the outcome of the proceeding. ... " Failure to strictly enforce the Excessive Fines Clause inevitably gives the government an incentive to investigate criminal activity in situations involving valuable property, regardless of its seriousness, but to ignore more serious criminal activity that does not provide financial gain for the government.

Id at 735 (citations omitted). For alternative circuit court tests, see United States $v$ Milbrand, 58 F3d 841, 844-48 (2d Cir 1995); United States $v$ Rural Route \#1, Box 224, 14 F3d 864, 874-76 (3d Cir 1994); United States v Chandler, 36 F3d 358, 362-65 (4th Cir 1994); United States v 9638 Chicago Heights, 27 F3d 327, 328-31 (8th Cir 1994); United States v 6380 Little Canyon Road, 59 F3rd 974, 982-86 (9th Cir 1995).

${ }^{208}$ Like all attorneys, prosecutors must not labor under actual or potential conflicts of interest. This restriction may be found not only in constitutional due process requirements, but in professional responsibility requirements. See $A B A$ Model Code of Professional Responsibility EC 5-1 at 1:323-24 (ABA 1995) (stating that lawyer's judgment should be free of "compromising influences and loyalties"), EC 5-2 at 1:324 (stating that lawyer should refuse client if reasonable probability that personal interests will affect adversely the services to be rendered); $A B A$ Model Rules of Professional Conduct Rule 1.7 comment 3 at 1:116 (ABA 1995) ("The lawyer's own interests should not be permitted to have adverse effect on representation of a client"), Rule 1.11 comment 1 at 1:129 (government lawyers subject to Rule 1.7 prohibition of conflicts). These or similar restrictions have been codified by the states to govern their attorneys, and additional state laws may mandate courts to disqualify prosecutors laboring under a conflict of interest, see, for example, People $v$ Eubanks, 14 Cal 4th 580, 59 Cal Rptr 2d 200, 206-09 (1996) (interpreting Cal Penal Code $\$ 1424$ to require disqualification where conflict renders it unlikely defendant will receive fair treatment), or to dismiss indictments obtained by biased prosecutors, see, for example, People $v$ Superior Court (Greer), 19 Cal 3d 255, 561 P2d 1164, 1165 n 5 (1977).

Federal prosecutors are governed by both state and federal rules of professional responsibility. The Model Code has been specifically applied to U.S. Attorneys by Justice Department regulation. 28 CFR § 45.735-1(b) (1986). Additionally, U.S. Attorneys are lawyers and as such are generally subject to the ethical rules of the state in which they practice, as many local federal court rules make clear. See, for example, U.S. District Court for Massachusetts Local Rule 83.6(4)(B); United States v Klubock, 832 F2d 649, 655 (1st Cir 1987). Moreover, conflicts may be criminally prosecuted under 18 USC \& 208(a) (1994) (prohibiting federal prosecutors from representing the government in any judicial proceeding in which they, their families, or their business associates have a financial interest, and punishing violations by a fine and up to five years imprisonment).

In Young $v$ United States, 481 US 787, 809 (1987), the Supreme Court reversed criminal contempt convictions because counsel for the beneficiary of the contempt order had been appointed to prosecute the contempt. The Court found that regardless of whether there was actual prosecutorial impropriety, the conflict created "the potential for private interest to influence the discharge of public duty," id at 805, and was so fundamental an error as to obviate any inquiry into prejudice. Id at 809-10. The court distinguished the po- 


\section{conduct, ${ }^{269}$ and the Supreme Court's emerging doctrines designed to protect states' rights against national power. Given the Su-}

tential conflict in Marshall $v$ Jerrico as too remote and therefore speculative. Id at 807. For other cases prohibiting prosecutorial conflicts, see Ganger $v$ Peyton, 379 F2d 709, 715 (4th Cir 1967); New Jersey $v$ Imperiale, 773 F Supp 747, 751-56 (D NJ 1991); People $v$ Zimmer, 51 NY2d 390, 434 NYS2d 206 (1980). For proposals to further regulate prosecutorial discretion, see ABA, Projection Standards for Criminal Justice, The Prosecution Function $\S \S 3-3.9(\mathrm{~d}), 3-1.3(\mathrm{a})$, (f) at 30-35 (ABA 1971); ALI, A Model Code of PreArraignment Procedure for Criminal Justice § 350.3(2)-(3) (ALI 1975); Kenneth Bresler, "I Never Lost a Trial": When Prosecutors Keep Score of Criminal Convictions, 9 Georgetown J Legal Ethics 537, 542 (1996) (Prosecutors "should not create individual incentives to seek convictions; they should seek justice."); Norman Abrahms, Internal Policy: Guiding the Exercise of Prosecutorial Discretion, 19 UCLA L Rev 1 (1971).

${ }^{209}$ Supreme Court dicta allowed that outrageous government misconduct may constitute a due process defense in United States $v$ Russell, 411 US 423, 432 (1973), and Hampton $v$ United States, 425 US 484, 490 (1976). But the doctrine has been only rarely invoked, and then primarily in entrapment situations where the government's conduct was deemed intolerable. (Unlike the entrapment defense, however, here the focus is purely on the government's conduct, and the defense is available even to a culpable defendant.) See, for example, United States $v$ Twigg, 588 F2d 373 (3d Cir 1978); United States $v$ BatresSantolino, 521 F Supp 744, 750-53 (N D Cal 1981). In a particularly relevant opinion, the Ninth Circuit found that a crime choreographed by an informant crossed this line because the informant was paid based on the conviction rate, the amount of drugs involved and the value of assets seized, but it withdrew the opinion after further argument successfully challenged the existence of these financial incentives. United States $v$ Solorio (9th Cir Aug 2 , 1994) (on file with U Chi L Rev), withdrawn and superceded by 52 F3d 827 (9th Cir 1995). The court's initial reasoning, however, should apply to future cases that do present the kind of rewards assumed in its first opinion:

[Such financial incentives create too great a risk evidence will be fabricated, and] it is extremely likely that innocent people will be prosecuted and convicted, and that informants will induce defendants to sell greater quantities of drugs than they are predisposed to sell.

$\cdots$

The danger is further exacerbated where the party with the financial incentive is the person orchestrating the crime. . . . Complete control over the "crime" makes "sting operations" an efficient law enforcement technique. However, this same feature creates enormous potential for abuse. When, as here, "sting operations" are combined with contingency fees designed to maximize the conviction rate and the amount of drugs, it is likely that this potential will become actual. At a minimum, the Due Process Clause protects against the conviction of individuals on the basis of evidence that has such a high risk of being false.

Solorio (withdrawn opinion) (on file with U Chi L Rev).

In some cases, the reverse stings favored by asset-hungry police agencies may violate the outrageous conduct doctrine. A federal district court so found in United States $v$ Santana, 808 F Supp 77, 79, 82 n 3 (D Mass 1992), where the government delivered 13.3 grams of 92 percent pure heroin to a suspect to gain his confidence, lost track of the drugs, and thereby sent 2,500 street doses into commerce. The court of appeals reversed the district court's dismissal, however, persuaded that the tactic was necessary and that the defendant had suffered no prejudice. United States $v$ Santana, 6 F3d 1, 8 (lst Cir 1993). Nevertheless, the opinion did reaffirm that sufficiently outrageous governmental conduct does mandate dismissal on due process grounds, and may warrant dismissal under the court's supervisory powers for the sole purpose of deterring government misconduct even in the 
preme Court's rapidly increasing interest in the latter issue, there may come a time when the adoptive forfeiture law-which permits local police departments to combine with the federal government in order to circumvent their own state forfeiture lawsis ripe for effective challenge on federalism grounds. ${ }^{270}$

Legislative reform efforts should also be pressed, especially because it appears highly likely that the 105th Congress will enact some measure of forfeiture reform in the coming year. ${ }^{271}$ Within Congress, Representatives as diverse as Hyde, Conyers, and Frank united in support of one bill that would institute some badly needed due process protections for persons whose property is seized. Based on proposals Congressman Hyde has been introducing since 1993, this bill would make the forfeiture laws fairer by strengthening the innocent owner defense, shifting the burden

absence of constitutional harm to a defendant. Id at 9, 11-12, citing United States $v$ Hasting, 461 US 499, 505 (1983). In the First Circuit and most others, the "outrageous misconduct doctrine, no matter how cramped its confines, is not entirely mummified," Santana, 6 F3d at 12, although it has been rejected by two circuits. See United States $v$ Tucker, 28 F3d 1420, 1423 (6th Cir 1994); United States $v$ Boyd, 55 F3d 239, 241 (7th Cir 1995).

While the outrageous conduct doctrine has been asserted as a defense to government entrapment efforts, the defense is much broader, at least in theory. The due process prohibition applies to prevent conviction brought about by any "methods that offend 'a sense of justice." Rochin $v$ California, 342 US 165, 173 (1952). There, pumping the stomach of a defendant to obtain swallowed capsules was found to violate the Due Process Clause. Id at 174. Rochin and subsequent cases have been identified as a separate line of authority prohibiting physical abuse of the defendant as "outrageous conduct" in violation of due process. See United States $v$ Kelly, 707 F2d 1460, 1476 n 13 (DC Cir 1983); United States v Bogart, 783 F2d 1428, 1438 (9th Cir 1986).

${ }^{270}$ This is not a prediction, but speculation on the Supreme Court's ultimate destination in developing new federalism doctrines. The Court has recently effected a sea change in the scope of federal power. See Printz $v$ United States, 117 S Ct 2365, 2384 (1997) (striking down a portion of the Brady Bill on grounds that it conscripted state officials to execute federal law); Seminole Tribe of Florida $v$ Florida, 116 S Ct 1114, 1125-28 (1996) (holding that the previously established congressional power to abrogate state immunity is limited to implementation of the Fourteenth Amendment and may not be invoked to implement its commerce power under Art I, § 8); United States $v$ Lopez, 514 US 549, 56768 (1995) (striking down the Gun Free School Zones Act as beyond Congress's Commerce Clause power); New York $v$ United States, 505 US 144, 174-77 (1992) (overturning a law that required the states either to enact radioactive waste legislation or take title to the waste). However, nothing in those cases would bar the kind of federal inducements that exist in the adoption law; unlike the Brady Bill, adoption does not require the states to provide services or spend money, but rather transfers money to those local agencies who wish to receive it. But such a scheme does profoundly alter the balance of federal and state powers, and it remains to be seen whether the Supreme Court might ultimately prove responsive to an argument that the federal government cannot constitutionally alienate local agencies from their state government in this way. For one opinion raising federalism concerns about federal adoptions, see Scarabin v Drug Enforcement Administration, 966 F2d 989, 994-95 (5th Cir 1992).

${ }^{271}$ On June 20, 1997, the House Judiciary Committee passed Congressman Hyde's proposed Civil Asset Forfeiture Reform Act, HR 1965, by a vote of twenty-six to one. 
of proof, and removing procedural obstacles to contesting forfeiture in court. ${ }^{272}$ Outside Congress, a broad-based coalition supports these procedural changes, including the National Association of Criminal Defense Lawyers, the American Bar Association, the ACLU, the Cato Institute, and even, to some extent, the Justice Department; but the Hyde Bill has lost the support of many forfeiture critics because its most recent incarnation added provisions that would greatly expand the reach of the forfeiture law. ${ }^{273}$

Moreover, pending forfeiture reform bills do not include any measures to rectify equitable sharing and other asset distribution provisions, or the conflict of interest and accountability problems that result, largely because of the continued, vigorous opposition of law enforcement. ${ }^{274}$ Congressman Hyde has omitted asset allo-

\footnotetext{
${ }^{272}$ See the proposed Civil Asset Forfeiture Reform Act, HR 1965, 105th Cong, 1st Sess (1997), and the Report of the House Judiciary Committee, HR Rep No 105-358 Part I (Oct $30,1997)$. As passed by the House Judiciary Committee, this Act would institute numerous procedural changes generally providing more protection to property owners, including a requirement that the government shoulder a burden of proving its case by a preponderance of the evidence, the provision of a court-appointed attorney for indigent claimants in some cases, the elimination of the bond required to challenge a seizure, compensation to the owner if the government negligently damages the seized property, an extension of the deadline for challenging a forfeiture to thirty days, requirement of notice to all identified interested parties within sixty days, and clarification of the federal "innocent owner" defense to include unknowing or unconsenting owners.

${ }^{273}$ The ABA in 1996 urged Congress to rewrite forfeiture laws to make them more just and equitable, and "restore public confidence that the civil forfeiture laws can and will be fairly deployed to fight crime, and not merely to further fiscal interests." Rhonda McMillian, Fairness in Civil Forfeiture, ABA J 102 (Nov 1996), quoting Terrance G. Reed, chair of the RICO, Forfeiture and Civil Remedies Committee of the ABA Criminal Justice Section, testifying before the House Judiciary Committee in July 1996 concerning the ABA's Statement of Principles on the revision of the Federal Asset Forfeiture Laws. Representatives of all of the other organizations named above testified or provided submissions to the House Judiciary Committee supporting some or all of the proposed reforms on June 11, 1997. See Report of the House Judiciary Committee, HR Rep No 105-358 at 36 (cited in note 272). However, the Justice Department's support of the Hyde Bill may hinge on other provisions that expand the reach of the forfeiture law, including Section 21 (forfeiture of proceeds traceable to facilitating property in drug crimes), Section 22 (forfeiture of proceeds of certain foreign crimes), Section 32 (forfeiture of additional money laundering offenses), Section 37 (forfeiture of instrumentalities of terrorism and telemarketing fraud), Section 38 (forfeiture of criminal proceeds transported in interstate commerce), and Section 40 (forfeiture of counterfeit paraphernalia). This in turn has driven away supporters of earlier versions of the Hyde Bill, including the ACLU. See ACLU Press Release, ACLU Says Changes in Civil Asset Forfeiture Bill Make Continued Support Impossible (July 22, 1997).

${ }^{274}$ Congressman John Conyers did include asset distribution reform in the unsuccessful bill he introduced in 1993, The Asset Forfeiture Justice Act, HR 3347, 103d Cong, 1st Sess (1993). The Asset Forfeiture Justice Act would have redirected 50 percent of the proceeds in the asset forfeiture program to community-based crime control efforts, drug education, and treatment programs, id at $\S 15$, and would have assured that forfeitures transferred to state or local agencies were disposed of according to the state's law, id at $\S \S 14$,
} 
cation reform from his bill despite its importance because, he says, "the financial considerations involved in the present federal adoption system mean unyielding opposition from law enforcement officials at all levels to any change in the law . . ." ${ }^{\prime 275}$ Representative Hyde's reluctance reflects his congressional experience. On the few occasions when Congress considered laws that would reduce the Drug War income stream, law enforcement wielded its abundant political power to soundly dispose of the threat.

The first such case occurred in 1988, after Congress passed a law requiring that Justice Department transfers of forfeited assets to a state be allocated according to the state's forfeiture law asset distribution formula. This amendment was designed to prevent local agencies from conspiring with the Justice Department to circumvent state forfeiture laws, which often earmark at least some of the assets for purposes other than law enforcement. By 1988, many police officials had learned that they could retain a larger percentage (at that time, 85 percent) of the assets by "federalizing" their seizures through Justice Department adoption and bypassing their own state's law. ${ }^{276}$ Congress responded by eliminating this option to escape state requirements, ${ }^{277}$ but its reform was short-lived. Under law enforcement pressure, Congress repealed the amendment before it could take effect. In its place, Congress substituted language requiring the Attorney General to "encourage further cooperation between the recipient State or lo-

17. But these proposals were cast aside, and Congressman Hyde did not include them in his reform bill because he believed such a bill would have no chance of getting through Congress. See text accompanying notes 275 and 283.

${ }_{275}$ Henry Hyde, Forfeiting Our Property Rights 68 (Cato Institute 1995). The Hyde Bill's failure to address asset distribution more directly prompted the National Association of Criminal Defense Lawyers to submit a written statement to the House Judiciary Committee, urging that it not "ignore the conflicts of interest and policy problems which arise when law enforcement and prosecutorial agencies reap financial bounty from the forfeiture decisions they make. Decisions regarding whose property to seize, and how to deal with citizens whose property has been seized is too often dictated by the profit the agencies stand to realize from the seizures." Civil Asset Forfeiture Reform Act, Hearings on HR 1916 before the House Committee on the Judiciary, 104th Cong, 2d Sess 310 (July 22, 1996) (prepared statement of E.E. Edwards, III, David B. Smith, and Richard J. Troberman, Co-Chairs of the National Association of Criminal Defense Lawyers Asset Forfeiture Abuse Task Force).

${ }^{226}$ See note 64 and accompanying text.

${ }^{27}$ This 1988 amendment included a provision stating, "The Attorney General shall assure that any [forfeited assets] transferred to a State or local law enforcement agency ... is not so transferred to circumvent any requirement of State law that prohibits forfeiture or limits use or disposition of property forfeited to State or local agencies." Asset Forfeiture Amendments of 1988, Pub L 100-690, $\S 6077$ (a), 102 Stat 4325, codified at 21 USC $\S 881(\mathrm{e})(3)(1988)$. 
cal agency and Federal law enforcement agencies, ${ }^{2278}$ even though it is precisely this cooperation that results in nullifying the state forfeiture distribution laws. A second, subsequent attempt also "went nowhere," according to its sponsor, "because law enforcement rallied and convinced everybody they needed those cuts of the pie."279

Law enforcement rallied again in 1994 and 1995, when Congress considered a Clinton Administration proposal to eliminate Byrne grants from the 1995 budget and substitute the funding of one hundred thousand additional police positions. Law enforcement agencies greatly preferred the Byrne Program, and launched a well-organized campaign to prevent the Byrne grant cut. ${ }^{280}$ Byrne grant money can be used to make more money through asset forfeiture, which makes law enforcement resistant to proposals that would kill the golden goose by diverting Drug War money to other law enforcement uses. Additionally, as the New Jersey Attorney General testified, many existing Byrnefunded drug enforcement jobs were at stake. ${ }^{281}$ In the end, the law enforcement lobby succeeded in obtaining full funding of both the Clinton police jobs bill and the Byrne Program. It even persuaded Congress to amend the program to allow continued funding of individual task forces beyond the forty-eight month limit Congress had earlier imposed to assure the grants would serve as seed money only.

\footnotetext{
${ }^{278}$ See 1989 amendment to 21 USC § 881(e)(3)(B), Pub L No 101-189, § 1215(a), 103 Stat 1569, codified at 21 USC $\$ 881$ (e)(3)(B) (1994).

${ }^{279}$ The sponsor was Congressman Bill Hughes, the original author of the federal adoption provision who had come to regret its impact. See Hyde, Forfeiting Our Property Rights at 68 (cited in note 275), quoting Hughes.

${ }^{250}$ Police witnesses testified to dire consequences if the Byrne program were not refunded, including "anarchy" in the cities, police inability to enforce of drug laws, and the general deterioration in the quality of American life. See Federal Assistance to State and Local Law Enforcement: The Proposed Elimination of the Byrne Block Grant, Hearing before the Committe on Government Operations of the House of Representatives, 103d Cong, 2d Sess app 1-3 (Mar 2, 1994).

${ }^{231}$ Department of Commerce, Justice, State, the Judiciary and Related Agencies: FY 1995 Appropriations, Hearings before the House Appropriations Committee, 103d Cong, 2d Sess (May 3, 1994) (statement of NJ Attorney General Deborah Poritz) (stating 404 police officials would lose their jobs if grants were eliminated). An additional factor, distressing to rural and suburban police forces, was fear that unlike Byrne grants, the funding for new police officers would be allocated based on population density. This turned out not to be the case. These new police positions were distributed "to a wide range of communities, including those in which violence was not a serious problem, leaving insufficient resources for the communities that were in greatest need." Philip Heymann and Jody Heymann, The Fate of Public Debate in the United States, 33 Harv J Leg 511, 518 (1996).
} 
This year the Justice Department has again circled the wagons around its Asset Forfeiture Fund, this time lobbying against a congressional proposal to appoint counsel for indigent claimants with money from the Fund. ${ }^{282}$

Congressman Hyde has concluded that at this point no legislation can prevail "that will take hundreds of millions-indeed, billions - of dollars away from the Justice Department and state and local agencies-away from the war on drugs." ${ }^{\text {283 }}$ Nevertheless, unless Congress wants to abandon any hope of regaining control over the Drug War bureaucracy it has created, it had better try to do so sooner rather than later.

The most obvious federal reform, and one that would cure both the conflict of interest and accountability hazards of the present system, would require forfeited assets to be deposited into the Treasury's General Fund. This one measure would restore congressional budgetary oversight and remove the incentive for police departments to distort their agendas for budgetary reasons. An alternative solution, identical in effect, would require that a law enforcement agency debit the value of any forfeited assets it retains from the budget it receives through congressional appropriation.

If Congress cannot or will not enact these fundamental reforms, there are lesser but still powerful steps it might take to ameliorate the particularly destructive impact of the adoption procedure. Adoption serves to provide police with a means of manipulative forum shopping without furthering any other, more legitimate purpose. Although we have seen how powerful the opposition can be, Congress should revisit this adoption law and either (1) repeal it, or (2) amend it to require that money given back to the states after an adoptive forfeiture be allocated according to state forfeiture law. ${ }^{284} \mathrm{~A}$ third alternative would pro-

${ }^{202}$ According to Richard Troberman, a member of the National Association of Criminal Defense Lawyers involved in discussions with the Justice Department and Congress over forfeiture reform, negotiations between reformers and the Justice Department foundered over this issue, the one procedural reform that would have directly affected the forfeiture income stream. Interview with Richard Troberman by authors, conducted April 1, 1997.

${ }^{233}$ Hyde, Forfeiting Our Property Rights at 66-67 (cited in note 275) (advising that forfeiture proceeds be deposited in the General Fund, and explaining why he has not proposed such a measure).

${ }^{224}$ The unsuccessful Conyers Bill, HR 3347, 103d Cong, 1st Sess (1993), included this option, and state officials have urged this reform. See, for example, Mississippi Attorney General Mike Moore and Jim Hood, The Challenge to States Posed by Federal Adoptive Drug Forfeitures 1, 3 (June/July 1992). We have seen that two previous attempts failed. See notes 277-79 and accompanying text. While failing to include it in his reform bill, Congressman Hyde suggests that procedural changes making federal forfeiture more diffi- 
hibit the Department of Justice from adopting a state forfeiture until a state court considers whether circumstances exist that justify bypassing the state forfeiture law.

Many state forfeiture laws also promote self-aggrandizing police practices and should be reformed. Few states replicate federal law in channeling virtually all forfeited assets to law enforcement. ${ }^{285}$ But those that do, and those that provide law enforcement with a direct and substantial share of the assets they seize, promote the abuses we have discussed. One leading reform organization, the National Conference of Commissioners on Uniform State Laws, has produced a model forfeiture act for states to consider. Its 1994 Uniform Controlled Substances Act mandates that forfeiture proceeds be deposited in the state treasury's general operating fund and subject to ordinary appropriation requirements because "earmarking funds [for law enforcement] risks skewing enforcement and prosecutorial priorities . . . ."286 During three years of debate leading to this provision, commissioners noted the "abuses . . . arising because millions and millions of dollars are going to people who may or may not be responsible and certainly are not accountable, ${ }^{\$ 287}$ as well as the

cult would encourage local and state police to use their own forfeiture laws. Hyde, Forfeiting Our Property Rights at 66-68 (cited in note 275).

${ }^{235}$ All states except Iowa and Vermont have forfeiture laws. Some allow forfeiture of assets only after a criminal conviction. See, for example, Missouri's Criminal Activity Forfeiture Act, Mo Ann Stat § 513.600-645 (Vernon Supp 1997). Some allow forfeiture of very limited kinds of assets or under very limited circumstances. See, for example, Cal Health. \& Safety Code $\$ 11469$ (West 1997) (mandating specific guidelines for police and prosecutors in order to ensure that law enforcement is the principal objective of forfeiture). Some require forfeited assets to be deposited in the general treasury. See, for example, NC Gen Stat § 90-112; NC Const Art IX, § 7; NM Stat Ann §§ 30-31-35, 22-8-32. Others specify a particular division among branches of law enforcement and some non-law enforcement entities. See, for example, 1997 NY Laws $\S 1349$ (40 percent to substance abuse service fund); Minn Stat Ann $\S 609.5315$ (1995) (70 percent to police, 20 percent to prosecutor, 10 percent to general fund); Mass Ann Law, ch 94C, § 47(d) (Michie/Law Coop 1995) (50 percent to prosecutor and 50 percent to police, but only since 1984). For a complete list of state statutes and their asset distribution provisions, see note 66 .

${ }^{256}$ National Conference of Commissioners on Uniform State Laws, Uniform Controlled Substances Act with Prefatory Note and Comments 4-5 (1994). Section 522(h) of the Uniform Controlled Substances Act states in pertinent part, "Money remaining after the satisfaction of the requirements of subsections (e) through (g) must be deposited in the [general fund] of the state." (brackets in original). The model law brackets the words "general fund" in recognition of the fact that some state constitutional provisions require that collections be shared with specified funds, such as an education fund. Subsections (e) through (g) give general directions for sale and/or disposal of property, and allow the transfer of a forfeiture action to a federal agency or agency of another state when that agency has contributed to the forfeiture.

${ }^{207}$ National Conference of Commissioners on Uniform State Laws, Proceedings in Committee of the Whole, Uniform Controlled Substances Act, Art V, Civil Forfeiture 114 
danger in "revolving funds where [expenditures do not] receive the review of the elected representatives of the people.".288 When prosecutors on the Commission were unable to block inclusion of this provision, they resigned and formed a separate organization to draft their own model forfeiture statute. ${ }^{289}$

No state law reform can be effective, however, so long as federal adoption continues to provide an escape route from state requirements. In proposing that state forfeitures be directed into the general fund, the Conference of Commissioners noted that without concurrent federal law reform "all forfeitures will go under federal law. ${ }^{290}$

Can these reforms be achieved? In proposing the above reforms, we do not underestimate the enormous obstacles to restructuring the asset distribution scheme, however obvious its destructive impact. Success will come, if at all, when the critics of self-financed police forces are able to focus public attention on the abuses and dangers that have thus far escaped sustained scrutiny.

(Aug 2-9, 1991) ("1991 Proceedings") (statement of Commissioner Harold E. Read, Jr.).

${ }^{238}$ Id (statement of Commissioner Bryce A. Baggett). At a later meeting, Baggett told the other participants that "this is the most important decision you'll make. The money is corrupting ... . Prosecutorial decisions are made on the basis of how much we can grab." National Conference of Commissioners on Uniform State Laws, Proceedings in Committee of the Whole, Uniform Controlled Substances Act Amendments, Art V, Civil Forfeiture 131-32 (July 30 to Aug 6, 1993) ("1993 Proceedings"). Other commissioners were equally concerned with the asset allocation issue. See 1991 Proceedings at 117 (cited in note 287) (statement of Commissioner John H. Langbein) ("It is deeply important that we recognize the venal conflict of interest that exists when law enforcement officers can basically line their pockets, not so much personally, but in terms of their appropriations, their perks, those Cadillacs .... When they are able to control their own appropriations by making individual arrests and so forth of citizens, you are in the worst kind of conflict of interest."); 1993 Proceedings at 115 (statement of Commissioner Michael Cramer) ("I think this is carrying privatization of public works a little too far. It creates an overzealous attitude which is incompatible with everything in the history of our law, or at least the way I perceive it should be.").

1993 Proceedings at 130-31 (statement of Commissioner Bryce A. Baggett) (cited in note 288). The prosecutors joined the President's Commission on Model State Drug Laws and published their recommendations for reform as the Commission Forfeiture Reform Act ("CFRA"). The CFRA "continues to allocate forfeiture revenues to law enforcement activities, with the exception of an optional diversion of ten percent of revenues to drug treatment programs .... [ [It] relies upon prosecutorial codes of ethics and conduct to prevent abusive forfeiture practices." Raymond P. Pepe, Alternative Proposals for the Reform of State Legislation Dealing with Forfeitures for Drug Offenses, 21 Wm Mitchell L Rev 197, 213-14 (1995) (citations omitted).

${ }^{200} 1991$ Proceedings at 118 (statement of Commissioner Donald E. Mielke) (cited in note 287). 


\section{CONCLUSION}

When Congress fundamentally restructured the forfeiture laws by allowing agencies to keep most of the assets they seize, it did so without considering the very substantial costs of these amendments to both the public welfare and the justice system. Now, more than a decade later, Congress can draw on an extensive and disturbing history to reassess the wisdom of these laws. This history is neither subtle nor ambiguous. Together with the narrow drug enforcement focus of the revised federal law enforcement aid program, the asset retention law has wrought a dramatic shift in police motivation, towards practices that seriously undermine rational law enforcement efforts. As we have seen, many police agencies choose the law enforcement strategies that will take maximum advantage of federal forfeiture laws, circumvent their own state forfeiture laws, and maximize property seizures-reducing fairness and crime control issues to an afterthought. Even the alleged mission of the Drug War may become secondary; failed policies are immune to reform because they sustain and profit the law enforcement agencies enlisted in this war.

Police abuses and warped law enforcement policy are only half of this disturbing story. We have also argued that police selffinancing raises serious accountability concerns, and threatens to establish a sector of permanent, independent, and selfaggrandizing police forces. This might sound promising to Colonel North or General Pinochet, but it should not be mistaken for a legitimate organ in a democracy.

The institutional mechanisms we have explored are but one part of an anti-drug mobilization that continues to have profound effects on the liberties and well-being of our people. We sink more deeply into this war year by year, failing to adequately examine or comprehend the choices we are making. ${ }^{291}$ Today commentators urge that we close the "revolving prison doors," apparently unaware that we already incarcerate far more people for longer time than almost every other industrialized country. ${ }^{292}$ Our politicians

${ }^{29}$ Many judges have noted how constitutional guarantees may be no match for the frenetic imperatives of the Drug War. See Torruella, 14 Yale J Reg at 256-57 (cited in note 60 ) (concluding that "citizens have been willing to give up their collective civil rights in the name of, and in exchange for, an illusory achievement of 'law and order' ... when it comes to those accused of drug violations"); Patricia M. Wald (Chief Judge of the D.C. Circuit Court of Appeals), A Report From the Front in the War on Drugs, 7 Ga St U L Rev 1, 4 (1990) ("Without vigilance, a fair, individualized system of criminal and civil justice could be an early [drug] war casualty.").

${ }^{202}$ See text accompanying notes $172-74$ (detailing the growing prison population of 
speak casually of enlisting the military, the National Guard, and the CIA to keep drugs away from the Americans who seek them, ${ }^{293}$ and for his part Mayor Rudolph Guiliani stations New York City drug police in the Dominican Republic. ${ }^{294}$ We routinely deploy numerous federal agencies, and massive numbers of federal and state agents, in military-style raids against low-level drug dealers. ${ }^{295}$ All of these changes, mostly unimaginable a gen-

nonviolent drug offenders). Speaker Newt Gingrich has gone so far as to craft the Drug Importer Death Penalty Act of 1997, HR 41, 105th Cong, 1st Sess $§ 2$ (Jan 7, 1997), in the 105th Congress, which would execute recidivist importers of any illicit drug where the quantities totaled one hundred times the usual dosage amounts on at least two occasions.

${ }^{203}$ For example, William Bennett has proposed putting the military in charge of the drug interception activities of the DEA, the FBI, and other agencies. Dreyfus, Rolling Stone at 45 (cited in note 167). Representative Bill McCollum, Chair of the Crime Subcommittee of the House Judiciary Committee, recently demanded "a massive deployment of Navy, Air Force, Coast Guard, and Customs ships, planes, radar, night vision surveillance equipment and the personnel to man them for an around-the-clock operation designed to totally disrupt the drug trafficking through the eastern Caribbean." Congressman Bill McCollum, A New Crisis in Drug Use, 142 Cong Rec H 11361-63 (Sept 26, 1996). In the 1996 presidential campaign, candidate Robert Dole advocated using "our military power, particularly our technological capabilities, to fight this [anti-drug] battle, to involve our intelligence agencies, including the CIA, in this effort." Editorial, Still on Drugs, The Progressive 9 (Oct 1996). See also Aaron Zitner, Dole Vows Guard Role in Drug War, Boston Globe A3 (Sept 2, 1996); Shenk, The Nation at 11 (cited in note 4). On the Democratic side, the continuing militarization of drug law enforcement is symbolized by President Clinton's appointment of a retired Gulf War general, Barry McCaffrey, as "Drug Czar," heading the Office of National Drug Control Policy. McCaffrey in turn has increased the staff positions several-fold and filled many of them with active-duty military officers. Dreyfuss, Rolling Stone at 42 (cited in note 167).

The Posse Comitatus Act, 18 USC $\S 1385$ (1994), prohibits direct military participation in purely domestic law enforcement operations, but has been amended to allow the military to gather information, give advice, lend equipment, and deploy personnel at the request of local law enforcement officials with jurisdiction over drug or immigration offenses. Department of Defense Authorization Act of 1982, Pub L No 97-86, 95 Stat 1115 (1981), codified at 10 USC $\S \S 371-85$ (1994). The proposal to further militarize the drug war threatens additional and unjustifiable abuses to life and liberty, as was recently illustrated by the shooting death of teenager Esequiel Hernandez, Jr. by marines on a drug surveillance mission in Redford, Texas. See Sam Verhovek, After Marine on Patrol Kills a Teen-Ager, a Texas Border Village Wonders Why, NY Times A16 (June 29, 1997) ("[C]ritics ... say the death of Mr. Hernandez, who had no criminal record and is not described by anyone as any kind of suspect in the drug trade, is a chilling example of the misunderstandings and the tragedies that they say will inevitably occur with the militarization of the border or any other patch of American soil.").

* Murray Weiss, Rudy to seal deal for NYPD's Dominican drug outpost, NY Post 2 (Nov 18, 1996) (reporting that "drug-fighting NYPD cops [will] make the streets safer for Dominicans who live in the Dominican Republic and for those nationals who live in New York City ...").

${ }^{206}$ See Sherry A. Dorsey, 17 Arrested on drug charges in N.H., Boston Globe 23 (June 22, 1995) (reporting on Operation Streetsweeper in New Hampshire, a June 1995 multijurisdictional task force operation deploying 150 officers to arrest seventeen low-level drug sellers and addicts and seize one gun). Alexander Cockburn notes that when the War on Drugs began in the late 1960s, there were only two federal agencies enforcing the drug 
eration ago, are largely the products of twenty-five years of trying (and failing) to "win" the War on Drugs. The first step towards recovery, which cannot come too soon, is to look at what we have done to ourselves, and what kind of institutions we have built, on the way to a "drug-free" society.

laws. He lists fifty-four today (including the DEA, NSA, IRS, DIA, ATF, State Department, Customs, Coast Guard, Army, Navy, Air Force, and Marines) with a federal budget of $\$ 13$ billion, with more than $\$ 800$ million going to the DEA alone. Alexander Cockburn, Beat the devil, The Nation 560, 561 (Nov 15, 1993). The anti-drug operations executed by these agencies include coastline interdiction by such agencies as the DEA's National Narcotics Border Interdiction System, the Coast Guard, and the Navy, including the firing on drug smuggling ships in international waters; NASA satellite surveillance; Treasury Department tracing of money laundering operations; CIA intelligence gathering about foreign drug sources; and State Department pressure on foreign governments to eradicate crops. Wisotsky, 38 Hastings L J at 892-93 (cited in note 161). 